\title{
ONTSTAAN EN ONTWIKKELING VAN DIE
}

\section{TRANSVAALSE VERDEDIGINGSMAG:}

\section{TRANSVAAL VOLUNTEERS}

\section{LOTGEVALLE VAN WITWATERSRANDSE UITLANDERS GEDURENDE DIE ANGLO-BOERE-OORLOG}

Die verdedigingsorganisasies van die twee voormalige Boererepublieke het met die beëindiging van die Anglo-Boere-oorlog verdwyn. In Oktober 1902 het daar in Transvaal 'n heeltemal nuwe militêre stelsel tot stand gekom wat geen verband met die vorige gehad nie.

Die Transvaalse verdedigingstelsel van na Oktober 1902 was suiwer volgens die Britse militêre tradisie van 'n vrywilliger-stelsel ingerig. Dit was inderdaad 'n voortsetting van Britse vrywilligerorganisasies wat gedurende die Anglo-Boere-oorlog uit Britgesinde inwoners van die Witwatersrandse gebied tot stand gekom het.

Om die ontstaan van die Transvaal Volunteers te kan begryp, moet dit teen die agtergrond van die lotgevalle van die Britse en Britsgesinde Uitlanderbevolking van die Witwatersrand gedurende die Anglo-Boere-oorlog gesien word.

Teen Junie 1899 het die naderende militêre botsing tussen Groot-Brittanje en die Zuid-Afrikaansche Republiek aan die Witwatersrand dié uitwerking gehad dat die vyandiggesinde deel van die Uitlanderelement senuagtige pogings begin aanwend het om die Republiek te verlaat. Tussen Junie en Oktober 1899 het ongeveer 90000 blankes hulle tuistes aan die Witwatersrand verlaat.

'n Rasionele verklaring vir dié gedeelte van die uittog wat van Junie tot die einde van September 1899 geduur het, is moeilik om te vind. Dit word beweer dat baie Uitlanders vreesbevange geword het deur wilde gerugte dat die Boere 'n soort St. Bartholomeusnag vir hulle sou beplan het. Volgens hierdie gerugte sou die Boere van plan gewees het om die Uitlanders se koppe met knipmesse af te sny. 'n Mens kan egter aanvaar dat die meeste vlugtelinge nie veel waarde aan so 'n riemtelegram sou heg nie. Vrees vir wat in geval van oorlog met hulle kon gebeur, moes die hoofrede vir die uittog van bogenoemdes gevorm het.

Die Republikeinse regering was bewus van die gevare verbonde aan die aanwesigheid van ' $n$ vyandiggesinde bevolkingselement aan die Witwatersrand indien oorlog sou uitbreek. Teen die einde van September 1899 is, op grond hiervan, tot daadwerklike optrede oorgegaan. Daar is bepaal dat alleen dié Uitlanders wat skriftelike verlof van die regering verkry het, aan die Witwatersrand kon bly, mits hulle sou onderneem om hulle stil, rustig en onderdanig te gedra. 
Hierdie kennisgewing is gevolg deur 'n waarskuwing van die Republikeinse regering dat alle Britse onderdane wat nie toestemming het om in die Republiek te bly nie, binne agt dae na 'n oorlogsverklaring moes padgee. Indien hulle nie hieraan gehoor sou gee nie, sou hulle volgens krygswet behandel word. Hierdie optrede van die Regering van die Zuid-Afrikaansche Republiek bied 'n verklaring vir die feit dat volgens skatting van die Standard \& Diggers News, net uit Johannesburg ongeveer 30000 blanke en 15000 nie-blanke Britse onderdane uit Johannesburg padgegee het gedurende die twee weke wat aan die uitbreek van die oorlog voorafgegaan het.

Sommige van hierdie uitgewekenes het hulle na die buiteland begewe, terwyl die oorgrote meerderheid hulle tydelik in stedelike sentrums soos Kaapstad, Kimberley, Pietermaritzburg, Port Elizabeth, Oos-Londen en Durban gevestig het.

'n Gedeelte van die pro-Britse uitgewekenes in dié stedelike sentrums het van tyd tot tyd by die Britse ongereelde berede vrywilligerskorpse (Irregular Mounted Volunteer Corps) aangesluit en in hierdie hoedanigheid aktief tot die stryd teen die Boererepubliek toegetree, terwyl die oorgrote meerderheid aanvanklik passief gebly het.

Sowel dié wat by Britse ongereelde berede korpse aangesluit het, as dié wat passief in die stedelike sentrums gebly het, het verwag dat hulle spoedig weer aan die Witwitwatersrand terug sou wees om met die normale bedryfslewe te kon voortgaan.

Johannesburg is egter eers op 31 Mei 1900 deur die Britse magte beset. Lord Roberts, die Britse militêre opperbevelhebber, het eers gedurende September van dieselfde jaar kans gesien om die uitgewekenes van die groter stedelike sentrums in Suid-Afrika geleidelik na die Witwatersrand te laat terugkeer. Hierdie en verdere vertragings het 'n skerp reaksie van die Uitlanders uitgelok. Die Britse Hoë Kommissaris in Suid-Afrika, sir Alfred Milner, moes vanuit Kaapstad die terugkeer van die uitgewekenes uit die stedelike sentrums na die Witwatersrand reël. Teen die einde van September 1900 het hy die nodige vervoerreëlings vir die vertrek van die eerste groep gekeurde uitgewekenes getref gehad.

Op daardie tydstip was dit sy plan om eers dié uitgewekenes te laat terugkeer wat na sy mening die nodigste sou wees om die sake- en bedryfsektore aan die Witwatersrand te laat herlewe. Vanweë die tekort aan voedsel en ander verbruikersgoedere aan die Witwatersrand sou die terugkeer van die uitgeweke Uitlanders aanvanklik baie geleidelik moes geskied. Die eerste groep sou nietemin aan die begin van Oktober na die Witwatersrand vertrek het.

Op 10 Oktober 1900 het lord Roberts aan sir Alfred Milner telegrafies versoek om aan Uitlanders wat voornemens was om terug te keer, bekend te maak dat van hulle verwag sal word om na hulle terugkeer aan die Witwatersrand militêre diens te verrig. Selfs hierdie nuus kon hulle geesdrif om terug te keer nie demp nie en aan hierdie reaksie kan gesien word hoe gretig die uitgewekenes teen daardie tyd was om na hulle tuistes terug te keer.

Die Uitlanders se vooruitsigte om 'n spoedige en algehele terugkeer na die Witwatersrand, is ewenwel skielik verydel toe lord Roberts die toestemming, wat hy gedurende September 1900 verleen het, op 13 Oktober 1900 onverwags ingetrek het.

Die rede vir hierdie stap was die ontevredenheid onder dié Witwatersrandse Uitlanders wat in ongereelde berede korpse te velde gedien het aangesien hulle onder die indruk was dat alle Randse Uitlanders wat passief in die stedelike sentrums gebly het, toestemming gekry het om na die Rand terug te keer. Volgens hulle moes hulle, op grond van hul aktiewe diens, eerste toegelaat word om terug te keer wanneer 'n algehele terugkeer van Randse Uitlanders ter sprake sou kom. 
Omdat die Witwatersrandse Uitlanders 'n groot deel van die Suid-Afrikaanse Koloniale kontingente te velde gevorm het, kon die Britse militêre owerhede dit nie bekostig om hulle op 'n kritieke tydstip van die oorlog van hulle te vervreem nie. Die oplossing vir die probleem was 'n algehele verbod op die terugkeer van uitgewekenes na die Witwatersrand.

Dit moet in gedagte gehou word dat die passiewe uitgewekenes in die stedelike sentrums op daardie tydstip in die meeste gevalle meer as 'n jaar van hul tuistes afwesig was. Langdurige werkloosheid het hulle in hulpbehoewende en ontevrede gemeenskappe laat ontwikkel. Na die hoop op spoedige terugkeer na die Rand verydel is, het die algemene ontevredenheid onder die lede van hierdie gemeenskappe nou in feitlike opstandigheid oorgegaan.

Hoe ironies dit ook al mag klink, het die Britse owerhede op dié stadium van die oorlog 'n werklik netelige Uitlanderprobleem ondervind. Die Westelike Provinsie, waar 6000 tot 7000 Boere as krygsgevangenes aangehou is, is slegs deur 'n paar Burgermagregimente beheer. Die bevolking van laasgenoemde gebied was oorwegend anti-Brits gesind, en 'n groot gedeelte van die Boerebevolking van die Kaapkolonie was inderdaad aktiewe rebelle.

Onder hierdie omstandighede was Milner veral bevrees vir 'n algemene opstand onder die Kaapse Boerebevolking. Dit kon volgens hom maklik gebeur, indien die Uitlanderelement tot daadwerklike opstand sou oorgaan en op dié wyse verdeeldheid in Britse geledere aan die lig sou bring.

As Hoof van die Generale Staf het lord Kitchener vroeg in November 1900 in 'n openbare verklaring verklaar dat die terugkeer van uitgeweke Uitlanders na die Witwatersrand gedurende Oktober 1900 om militêre redes afgelas is. Hy het verder verklaar dat die aangeleentheid die ernstige aandag van die militêre owerhede geniet en dat die algemene terugkeer toegelaat sou word sodra die militêre situasie dit toelaat. Terselfdertyd het Kitchener 'n beroep op alle liggaamlik geskikte Witwatersrandse Uitlanders in die stedelike sentrums gedoen om by bestaande Britse berede vrywilligerkorpse aan te sluit of om nuwe korpse te stig en aktief tot die stryd toe te tree. Op hierdie wyse kon hulle meehelp om die oorlog tot 'n spoedige einde te bring en hulle eie terugkeer, sowel as dié van hulle mede-Uitlanders, help bespoedig.

Hierdie oproepe het tot gevolg gehad dat baie Uitlanders in die stedelike sentrums as berede troepe by ongereelde vrywilligerkorpse aangesluit het.

Die oorsaak van die ontevredenheid en opstandigheid van die Uitlanders in die stedelike sentrums wat nie by berede korpse aangesluit het nie, was hierdeur vanselfsprekend nog nie opgelos nie. Trouens, die verloop van die oorlog het dit eerder laat vererger.

Sedert Oktober 1900 het die Boeremagte die spoorverbindings tussen die hawestede en Johannesburg in só 'n mate ontwrig dat die voorrade in Johannesburg kwalik voldoende was om die besettingsmag en die plaaslike inwoners van voedsel te voorsien. Die gevolg was dat die terugkeer van Uitlanders na die Rand vir 'n onbepaalde tyd uitgestel moes word.

As Hoë Kommissaris in Suid-Afrika was Milner gemoeid met die probleem van die ontevredenheid en opstandigheid van die Randse Uitlanders in die stedelike sentrums. Behalwe om hulle ontevredenheid tot bedaring te probeer bring, was daar vir hom 'n ander belangrike rede vir die spoedige terugkeer van Uitlanders na die Rand. Hy was daarvan oortuig dat daar aan die Witwatersrand, verkieslik in Johannesburg, 'n daadwerklike begin gemaak moet word met die hervestiging van 
nywerhede en sake-ondernemings. Volgens hom sou dit grootliks daartoe bydra dat die Boere die nutteloosheid van hulle weerstand sou insien. So 'n besef sou dus 'n sterk sielkundige faktor wees wat tot 'n spoedige beëindiging van die oorlog kon bydra.

Reeds teen die einde van Oktober 1900 het Milner aan Kitchener voorstelle gemaak dat die terugkeer van die Uitlanders na die Witwatersrand gekombineer moes word met die oprigting van Uitlander-vrywilligerkorpse. Die kern van sy betoog was dat dit vir die Britse militêre owerheid goedkoper sou wees om die teruggekeerde Uitlanders in hulle plekke van herkoms as vrywilligers te versorg as om hulle in die stedelike sentrums as mutinous grumblers te onderhou.

Vrywilligerkorpse wat op hierdie wyse deur Uitlanders gevorm sou word, kon volgens Milner, 'n groot deel van die Britse gereelde troepemag wat aan die Witwatersrand garnisoendienste verrig het, vir aktiewe diens vrystel. Andersyds sou daar, soos hy dit gesien het, beslis bykomende troepe nodig wees om die Uitlanders in die groter stedelike sentrums buite Transvaal te beheer indien die Uitlanders nie spoedig toegelaat sou wees om na die Witwatersrand terug te keer nie.

'n Volgende uitgangspunt van Milner se gedagtegang was, dat indien die Witwatersrandse Uitlanders te velde nie kon insien dat die geleidelike terugkeer van gekeurde Uitlanders van die stedelike sentrums na die Witwatersrand in hulle eie belang sou wees nie, hulle toegelaat moes word om hulle dienste as berede vrywilligers te beëindig en self na die Witwatersrand terug te keer. Hulle, tesame met ongeveer 20000 uitgewekenes uit die stedelike sentrums, sou min of meer drie maal soveel vrywilligers oplewer as die aantal Randse vrywilligers wat op dié tydstip in ongereelde berede korpse te velde gedien het. Met só 'n mag, het Milner geredeneer, kon nie net Johannesburg nie, maar die hele Witwatersrand beveilig word. Hierdeur sou die heropbou van nywerhede en sake-ondernemings vergemaklik word.

Milner kon, alleen in sy hoedanigheid as Hoë Kommissaris aanbevelings doen, terwyl die Britse militêre opperbevelhebber in Suid-Afrika die beleid bepaal het. Alhoewel sy voorstel nie ten volle aanvaar en deurgevoer is nie, het dit tog 'n groot invloed uitgeoefen. Sowel Roberts as Kitchener was oortuig van die ekonomiese en politieke voordeel wat die herstel van die nywerheids- en sakelewe aan die Witwatersrand sou meebring. Albei het gedurende hulle onderskeie ampstermyne as opperbevelhebbers hierdie oogmerk nagestrewe as een van dié maatreëls om die einde van die oorlog te bespoedig.

As 'n uitvloeisel hiervan is twee ongereelde vrywilligerkorpse, t.w. die Railway Pioneer Regiment en die Rand Rifles, in die lewe geroep met as doel die beskerming van die Witwatersrand en die onmiddellik aangrensende gebiede.

Die Railway Pioneer Regiment het ontstaan as gevolg van die algemene ontevredenheid en opstandigheid onder die uitgeweke Uitlanders in die stedelike sentrums teen die begin van November 1900. Hierdie ontevredenheid het toe sodanige afmetings aangeneem dat die Uitlanders reeds massavergaderings belê het, wat vroeg in November sou plaasvind.

'n Afvaardiging, bestaande uit genl.-maj. sir E. Y. Brabant, K.C.B., C.M.G., M.L.A., en sir George H. Farrar, D.S.O., was op dieselfde tydstip in Kaapstad besig om troepe onder die Uitlanders vir Britse berede ongereelde vrywilligerkorpse te werf. Hulle het by Milner aanbeveel dat soveel van die liggaamlik geskikte Uitlanders as wat kon perdry en skiet, by berede korpse moes aansluit, terwyl dié wat nie vir diens in berede korpse geskik was nie, in 'n infanteriekorps vir garnisoendienste opgeneem moes word. 
Die oprigting van 'n Uitlander-infanteriekorps was vir Milner een van die laaste uitweë om opstand onder die Uitlanders in die stedelike sentrums te verhoed. Daarom het hy die hoër militêre gesag versoek om onmiddellik hiermee te begin. As Britse opperbevelhebber het lord Roberts die gedagte gesteun. Hy was van mening dat 'n ongereelde korps van Uitlander-infanteriste op dié stadium van die oorlig nuttig aangewend kon word. Verder was hy ook daarvan oortuig dat die militêre aanwending van 'n gedeelte van die uitgeweke Randse Uitlanders in stedelike sentrums daartoe sou bydra om die ontevredenheid onder hulle te laat afneem.

In November 1900 is 1t.-kol. J. E. Capper gelas om die talryke Uitlanderkomitees in groter sentrums te raadpleeg en om dan 'n gedetailleerde skema vir die oprigting van die beoogde korps uit te werk. Teen die einde van November 1900 het lt.-kol. Capper, bygestaan deur 'n breë Uitlanderkomitee, die besonderhede van die beoogde skema gereed gehad en dit aan die Uitlanderkomitees van Durban, Kimberley, Oos-Londen en Port Elizabeth vir goedkeuring voorgelê.

Die voorgestelde voorwaardes vir aansluiting by hierdie korps was die volgende:

a. Driloefeninge sou nie te moeilik wees nie, maar die omvang daarvan sou aan die diskresie van die bevelvoerende offisier ooirgelaat word.

b. Liggaamlike fiksheidstoetse vir aansluiting by dié korps sou laer wees as die vir berede korpse.

c. Weermanne sou teen vier sjielings per dag besoldig word, terwyl voedselrantsoene, uniforms en persoonlike uitrustings gratis verskaf sou word.

d. Die gebied waarin die korps diens sou verrig, is duidelik omskryf as 'n streek om die Witwatersrand, Rustenburg en Pretoria. Die Delagoabaaispoorlyn sou die noordelike- en die Vaalrivier die suidelike grens van dié gebied vorm, terwyl die oostelike en westelike begrensings die lengtegrade sou wees wat respektiewelik deur Standerton en Potchefstroom loop. Indien dit nodig sou word, kon die korps ook langs die spoorlyn noord van Kroonstad diens verrig.

e. Die korps sou alleen in die Witwatersrandse gebied diens verrig as militêre oorwegings dit absoluut noodsaaklik sou maak.

f. Die duur van die dienstydperk sou bepaal word deur die behoefte van die militêre owerhede om die diens van die korps te benodig. Na voltooiing van ses maande diens, sou indiwiduele korpslede toegelaat word om na enige plek buite Transvaal of die Oranje-Vrystaat te vertrek.

g. Sodra die militêre situasie dit sou toelaat, sou lede van die korps verminder word. Indien dit sou gebeur nadat reeds weer met kommersiële- en nywerheidsarbeid aan die Witwatersrand begin is, sou korpslede wat privaat eienaars van besighede aan die Witwatersrand was, of lede wat kon waarborg dat hulle aldaar in betrekkings in diens geneem sou word, eerste toegelaat word om te vertrek.

h. Die militêre owerheid sou probeer om die Transvaalse Kamers van Mynwese en Handel te oorreed tot 'n belofte om, na die oorlog, voorkeur te gee aan die indiensneming van oud-werknemers wat in die korps gedien het.

i. Normaalweg sou korpslede se dienste tot verdedigingsposte òf tot werk naby ò tussen sodanige poste beperk wees. Lede moet egter bereid wees om enige infanteriewerk binne die afgebakende gebied te verrig as dit van hulle vereis word. Lede wat by die spoorlyne diens gedoen het, moes bereid wees om tydelike herstelwerk aan dié lyne uit te voer.

j. Die militêre owerhede sou oorreed word om offisiere vir die korps aan te stel uit 'n naamlys van persone wat deur die Uitlanderkomitees aanbeveel word. 
k. Die naam van die nuwe korps sou die Railway Pioneer Regiment wees.

Hoewel daar geen dokumentêre bewyse gevind kon word dat bogenoemde skema aanvaar is nie, kan aangeneem word dat dit wel die geval was. Kitchener het, as Hoof van die Generale Staf, die basiese beginsels van die skema goedgekeur, terwyl Milner dit in sy geheel ten volle gesteun het.

Die korps het bestaan uit bataljons van 500 man sterk, elkeen met 'n majoor aan die hoof. Die eerste bataljon het gedurende Desember 1899 tot stand gekom. Vanaf Desember 1900 tot aan die einde van die oorlog het nog drie bataljons tot stand gekom, wat onderskeidelik as die tweede, derde en vierde bataljon van die Railway Pioneer Regiment bekend gestaan het.

Die taak van laasgenoemde bataljons was hoofsaaklik tot die instandhouding van spoorweë in die afgebakende gebied om die Witwatersrand beperk. Volgens Stirling het die diensdoende lede hulle tot aan die einde van die oorlog goed van hul taak gekwyt.

Van Desember 1900 tot aan die einde van die oorlog het die onderhawige bataljons nie juis in militêre operasies verwikkeld geraak nie. In sy werk Colonials in South Africa, (London, 1907) maak Stirling van slegs een geval melding waar die korps op 'n noemenswaardige wyse operasioneel betrek is. Dit was op 20 November 1901 naby Villiersdorp. By hierdie geleentheid het ses man gesneuwel en is ses gewond.

Tydens die oprigting van die tweede bataljon van dié korps het Milner die hoop gekoester dat dit die kern van 'n na-oorlogse verdedigingsmag aan die Witwatersrand sou vorm. Aan hierdie verwagting is op indirekte wyse voldoen, want toe die infanterie-eenheid, die Witwatersrand Rifles, op 1 Mei 1903 ingestel is, was die aanvanklike ledetal daarvan grotendeels lede van die vroeëre Railway Pioneer Regiment, wat op 30 April 1903 ontbind is.

In 'n artikel getiteld Transvaal Volunteers: The Johannesburg Regiments poneer Stirling trouens die volgende stelling:

After the proclamation of peace and the formation of volunteer regiments, the Witwatersrand Rifles rose from the ashes of the Railway Pioneer Regiment.

Gelyktydig met die oprigting van die tweede bataljon van die Railway Pioneer Regiment, gedurende November 1900, het die Britse militêre owerheid begin om 'n vrywilligermag vir die verdediging van die Witwatersrandgebied te stig. Hierdie mag sou bestaan uit die Britse bevolkingselement wat aan die Witwatersrand woonagtig was.

Met die oprigting hiervan is 'n tweeledige doelstelling nagestrewe: Ten eerste was die oogmerk die militêre opleiding en bewapening van terugkerende Uitlanders, met die verwagting dat op dié wyse 'n verdedigingsmag van sowat 20000 man op die been gebring kon word. Daar is gehoop dat die mag sterk genoeg sou word om doeltreffende weerstand teen enige vyandelike mag in Suid-Afrika te kan bied. Dit sou beskerming aan die Witwatersrand verleen om die nywerhede (veral die myne) en die sakelewe so gou as moontlik weer aan die gang te laat kom.

Tweedens is gehoop dat dié mag na vredesluiting die kern van 'n permanente verdedigingsorganisasie vir Transvaal sou vorm.

Hierdie korps is op 18 Desember 1900 amptelik onder die naam Rand Rifles ingestel en van 27 Januarie 1901 af kon die lede hul werksaamhede begin. Gedurende die nag van eersgenoemde datum het 'n gedeelte van die manskappe vir die eerste keer wagposte in die buitewyke van Johannesburg beman. 
Teen 31 Januarie 1901 was die korps in staat om vir die beveiliging van Johannesburg in te staan en kon die tweede bataljon van die Prince of Wales (North Staffordshire)-regiment, wat die garnisoendienste in Johannesburg sedert die begin van die Britse besetting behartig het, op die genoemde dag die stad verlaat om aktiewe diens te velde te verrig.

Spoedig na die oprigting van die Rand Rifles is die geledere van die korps onverwags heelwat uitgebrei deur die toevoeging van 'n Mines Division. Hierdie ontwikkeling het gevolg op die eerste poging van Boerekant om die myne te beskadig. Op 26 Desember 1900 het generaal Piet Viljoen, met 'n mag van sowat 350 man, 'n artillerie-aanval op die New Kleinfontein-myn geloods en binne 'n kort tydjie 'n beraamde skade van $\pm £ 210.000$ aangerig. As gevolg hiervan is onderhandelings oor die oprigting van mynwagte reeds van vroeg in Januarie 1901 af tussen die Transvaalse Kamer van Mynwese, waarvan die verteenwoordigers op die stadium in Kaapstad was, en die Britse opperbevelhebber gevoer.

Teen die helfte van Januarie 1900 is tot 'n ooreenkoms in dié verband geraak. Die Transvaalse Kamer van Mynwese het onderneem om 1500 oud-mynwerkers en -amptenare wat as uitgewekenes in ander stedelike sentrums gewoon het, as mynwagte na die Witwatersrand terug te bring. Dié wagte sou hulle militêre uitrusting en -toerusting gratis van die militêre owerhede ontvang, terwyl indiwiduele mynmaatskappye finansiële aanspreeklikheid aanvaar het vir die besoldiging van hulle wagte en ook vir die voedselrantsoene wat deur die militêre owerheid uitgereik sou word. By hulle aankoms aan die Witwatersrand sou lede van die mynwagte vir militêre beheer by die Rand Rifles ingeskakel word. Hulle sou nie toegelaat word om 'n betrekking aan die Rand te aanvaar nie, maar moes slegs as mynwagte funksioneer. Hierdie geleentheid is as só dringend beskou dat die eerste 518 mynwagte reeds gedurende die eerste week van Februarie 1901 van Stellenbosch af, waar hulle 'n week lank militêre opleiding ontvang het, na die Witwatersrand vertrek het.

In die ware sin van die woord was die Rand Rifles nie 'n vrywilligerorganisasie nie. In die proklamasie waardeur die instelling daarvan gepromulgeer is, is bepaal dat alleen liggaamlik geskikte Britse inwoners van die Witwatersrandse gebied toegelaat sou word om by die korps aan te sluit. In die praktyk was alle Britse inwoners van die Witwatersrand egter verplig om by die mag aan te sluit en was hulle, by versuim, skuldig aan 'n oortreding en onderhewig aan straf deur die militêre goewerneur van Johannesburg. Verder moes alle Uitlanders wat permitte gekry het om na die Witwatersrand terug te keer, skriftelik onderneem om na hul aankoms by die Rand Rifles aan te sluit. By versuim sou hulle, kragtens krygswet, weer uit die gebied verwyder kon word.

Die Rand Rifles het uit drie verskillende afdelings, t.w. 'n berede afdeling, 'n afdeling vir fietsryers en 'n infanterie-afdeling, bestaan en is, ooreenkomstig die distrikte van die Witwatersrandse gebied, in kompanies ingedeel. Lede moes behoort aan die kompanie van die distrik waanin hulle gewoon het of waarin hulle besighede geleë was.

By gebrek aan bronnemateriaal is dit nie moontlik om die organisatoriese opset van die Rand Rifles volledig weer te gee nie. Die hoofkwartier van die korps was in Johannesburg, waar ook verskeie distrikskantore oftewel kompaniehoofkwartiere gevestig was, soos ook die geval was in groter Randse sentrums buite Johannesburg. Administratief het die Rand Rifles aanvanklik onder die militêre goewerneur van Johannesburg geressorteer. Toe hierdie pos aan die einde van April 1901 afgeskaf is, het Rand Rifles vanaf Mei 1901 onder die Bevelvoerende Offisier van die Witwatersrandse gebied geval. Dit het egter spoedig geblyk dat die siviele regering van 
Transvaal, wat in April 1901 tot stand gekom het, daarin belang gestel het om hierdie korps ná die oorlog as 'n permanente vrywilligermag vir die verdediging van die Transvaal-kolonie oor te neem.

Teen die einde van April 1901 het die Transvaalse Uitvoerende Raad 'n finansiële toesegging van $£ 5.000$ uit die winste wat deur die Civil Supplies Department gemaak sou word, aan die korps gedoen. Tegelykertyd het die Transvaalse regering hom bereid verklaar om jaarliks $£ 10.000$ vir hoofdelike toelaes aan weerbare lede van die korps te stem sodra die korps behoorlik as 'n permanente vrywilligermag georganiseer sou wees.

Voordat Milner op 8 Mei 1901 na Engeland vertrek het, het hy en Kitchener samesprekings oor die toekoms van die korps gevoer. In beginsel het hulle besluit dat dit volgens die regulasies vir Britse vrywilligerkorpse ingerig sal word. Kleiner wysigings, om by plaaslike omstandighede aan te pas, sou egter nodig wees. Dit sou beteken dat die siviele regering vir die betaling van hoofdelike toelaes sowel as vir die salariëring van die permanente opleidingstaf, wat uit offisiere en onderoffisiere van die Imperiale Staande Mag bestaan het, verantwoordelik sou wees.

Aan die lede van Rand Rifles is gratis uniforms, gewere, bandeliers en ammunisie vir skietoefeninge uit imperiale voorrade in Suid-Afrika uitgereik. Hieruit het Kitchener afgelei dat die korps ook na die vredesluiting, wanneer dit 'n permanente vrywilligerorganisasie vir die Transvaal-kolonie sou wees, onder die War Office en die Britse militêre opperbevelhebber in Suid-Afrika sou ressorteer.

Van 1 Desember 1901 het die Transvaalse regering steeds finansiële aanspreeklikheid vir die korps aanvaar. Nog gedurende dié maand het Milner byna 'n proklamasie uitgevaardig waarkragtens die Rand Rifles onder beheer van die Administrateur van Transvaal, d.w.s. onder siviele beheer, geplaas sou word. Volgens die betrokke konsepproklamasie sou die korps saamgestel word uit alle blanke Britse onderdane woonagtig in die gebied wat voorheen onder jurisdiksie van die mynkommissarisse van Boksburg, Johannesburg en Krugersdorp geval het. Hieruit blyk dat Milner na dié stadium 'n na-oorlogse verdedigingsmag vir die Transvaal-kolonie beoog het wat deur die siviele regering beheer sou word en wat volgens die beginsels van diensplig sou funksioneer.

Kitchener het verhoed dat hierdie proklamasie uitgevaardig is. Volgens hom sou 'n dergelike voorneme die karakter van die Rand Rifles verander. Hy het gemeen dat die korps na die vredesluiting heeltemal in 'n vrywilligerorganisasie van sowat 5000 lede omskep moes word. Dit moes dan onder beheer van die Britse militêre opperbevelhebber in Suid-Afrika geplaas word. Nie alleen vanweë dissiplinêre oorwegings was Kitchener teen siviele beheer oor die toekomstige Transvaalse koloniale verdedigingsmag gekant nie, maar hy was veral bevrees dat dit teen imperiale belange kon indruis. Indien Transvaal later verantwoordelike regering sou kry, sou die Transvaalse premier volle beheer oor die korps hê.

As gevolg van Kitchener se houding het die Rand Rifles na Desember 1901 onder militêre beheer gebly.

Die sterkte van die Rand Rifles kon nie vir enige gegewe tydstip van sy bestaan uit geraadpleegde bronne vasgestel word nie. Daar moet egter onthou word dat die uitbreiding van die korps eweredig was aan die tempo waarteen Britse onderdane onder die uitgeweke Uitlander-element hulle weer aan die Rand gevestig het. Verpligte korpslidmaatskap van Britse onderdane is eers teen Junie 1902 opgehef. Daar kan dus aanvaar word dat die Rand Rifles ten tye van sy ontbinding op 10 Oktober 1902 'n omvangryke organisasie was. 
Gedurende die tydperk van sy bestaan het die Rand Rifles nie geleentheid gehad om hom as gevegsmag in 'n groot militêre botsing te onderskei nie. Die eenheid het slegs by enkele geleenthede aan kleiner skermutselings deelgeneem. Hierdie feit is 'n bewys dat die korps wel daarin geslaag het om die Witwatersrand na Januarie 1901 voldoende vir die hervestiging van die nywerhede en die handel te beveilig.

Die betekenis van die Railway Pioneer Regiment en die Rand Rifles was dat die oorgrote meerderheid van die Rand se Uitlanders wat nie gedurende die oorlog by ongereelde berede vrywilligerkorpse aangesluit het nie, deur aansluiting by hierdie korpse militêre opleiding ontvang en militêre ondervinding opgedoen het.

$\mathrm{Na}$ afloop van die oorlog, toe ook dié Uitlanders wat by ongereelde berede korpse ingedeel was, hulle in dié gebied gevestig het, het die Witwatersrand 'n ware „,militêre bevolking" gehuisves. Omdat hierdie bevolkingselement oorwegend pro-Britsgesind was, was toestande aan die Rand net na die oorlog uiters gunstig vir die ontstaan van 'n permanente vrywilligerorganisasie as verdedigingsmag vir die Transvaal-kolonie. 


\section{DIE ONTSTAAN VAN DIE}

\section{"TRANSVAAL VOLUNTEER CORPS"}

Onmiddellik na die Anglo-Boere-oorlog was daar geen dringende noodsaaklikheid vir 'n permanente verdedigingsmag in Transvaal nie.

Die Boere is voor en na die vredesluiting in 1902 geheel en al ontwapen. Hulle was oorlogsmoeg en sou, 'n geruime tyd na die oorlog, hulle tyd en kragte grotendeels aan die heropbou van hulle vernielde eiendomme moes wy. Milner het vir die onmiddellike dus geen rede tot vrees vir hernude opstande gehad nie.

Die enigste werklike gevaar in Transvaal, en trouens in die res van Suid-Afrika, was die groot Bantoebevolking wat deur die oorlog ontwrig is en moontlik daarna tot opstand kon oorgaan. Selfs hierdie gevaar het die organisasie van 'n permanente verdedigingsmag in Transvaal na die oorlog nie spoedeisend gemaak nie. Trouens, na 1902 het 'n toereikende getal Imperiale troepe in Suid-Afrika agtergebly om enige probleem-situasie die hoof te kon bied.

Die was die ongereelde berede vrywilligerkorpse wat gedurende die oorlog deur uitgeweke Witwatersrandse Uitlanders gevorm is, wat net na die oorlog as 'n faktor na vore gekom het om die organisasie van 'n permanente verdedigingsmag te verhaas.

Aan die begin van Junie 1902 het Kitchener die aandag gevestig op die feit dat dit volgens hom 'n fout sou wees om ongereelde vrywilligerkorpse na die ontbinding daarvan heeltemal van die toneel te laat verdwyn. Hy het dan ook by Milner aanbeveel dat dié van hulle wat gedurende die oorlog voortreflike diens gelewer het, as permanente vrywilligerkorpse gehandhaaf moes word. Hierdie korpse kan dan die kern van 'n permanente vrywilliger-organisasie vir Transvaal vorm.

Kitchener het verder voorgestel dat die Imperiale regering perde en toerusting aan die volgende ses berede korpse van die Transvaalse regering moes skenk, nl. aan die Ist Imperial Light Horse, die 2nd Imperial Light Horse, die South African Light Horse, die Johannesburg Mounted Rifles, die Scottish Horse en die Kitcheners Scouts.

Die voorgestelde geskenk sou neerkom op perde en toerusting vir 3000 berede vrywilligers. Verder het hy voorgestel dat die Transvaalse regering, tot bevrediging van die Britse militêre opperbevelhebber in Suid-Afrika, verantwoordelik gehou moes word vir die instandhouding van die geskenk. Nog 'n voorwaarde, in geval die skenking 'n werklikheid sou word, sou wees dat die Britse regering die perde en toerusting te eniger tyd sou kon terugeis wanneer hulle vir Impeniale doeleindes benodig sou word.

Milner het die voorstel gesteun en was daarvan oortuig dat daar meer as genoeg vrywilligers in Transvaal beskikbaar sou wees om die voorgestelde berede korpse op volle sterkte te hou.

Dié voorgestelde militêre organisasie sou tot gevolg hê dat die Britse regering, sonder groot uitgawes, 'n werklik waardevolle plaaslike verdedigingsmag in Transvaal beskikbaar sou hê. Hierdeur kon die sterkte van die duur na-oorlogse Britse garnisoen in Suid-Afrika wesenlik verminder word. 
Omdat die betrokke ongereelde berede vrywilligerkorpse kort na die oorlog ontbind moes word, was vinnige optrede noodsaaklik vir die verwesenliking van Kitchener se voorgestelde militêre organisasie. Kitchener het onmiddellik met die War Office in verbinding getree om van die Secretary of State for War toestemming vir die voorgestelde geskenk van die Imperiale regering aan die Transvaalse koloniale regering te verkry. Hierdie toestemming is op 10 Junie 1902 ontvang.

Om die yster te smee terwyl dit nog heet was, het Milner aan Kitchener versoek om voor sy vertrek na Engeland 'n toespraak te hou waarin hy die vrywilligerbeweging moes aanmoedig. 'n Geskikte geleentheid hiervoor was tydens 'n dinee wat op 17 Junie 1902 in Johannesburg ter ere van die vertrekkende opperbevelhebber gegee is. Volgens beriggewing in die Cape Times van 29.6.1902 het Kitchener hom in sy toespraak soos volg oor die toekoms van die vrywilligers in Transvaal uitgelaat:

Keep up the glorious organisations of these distinguished regiments to which you belonged. Treat those youths that come after you with what you have learned. Keep your horses and your rifles ready, and your bodies physically fit, so that you may be prepared at any time to take your due part in that great Empire which unites us. (Loud applause). You may well say: This is all very well in theory, but how can it be practical? Well, I have been able to arrange with the Home Government and Lord Milner that 500 1st I.L.H.*, 500 2nd I.L.H., 500 S.A.L.H., 500 J.M.R., 500 K.F.S., 500 Scottish Horse shall retain, without preliminary cost, their horses, rifles and equipment, with the sole proviso that they shall be maintained by the Civil Government in a state of efficiency, and may be called by the military authorities if they require them. (Loud and long continued applause). I have already referred to the contemplation of the great mine-owners who are, I fully believe and trust, prepared to support this movement, by giving lucrative employment to men.

Should they do so, I think the practical difficulties of carrying out this scheme may be said to be overcome, and I may with confidence leave the rest to you, feeling sure that what we all wish will be accomplished. (Applause).

Op 7 Julie 1902 is die volgende ongereelde berede vrywilligerkorpse ontbind: Die Ist Imperial Light Horse, die 2nd Imperial Light Horse, die Johannesburg Mounted Rifles, die 1st Kitcheners Fighting Scouts, die 2nd Kitcheners Fighting Scouts, die Ist Scottish Horse, die 2nd Scottish Horse en die African Light Horse.

Vier dae later is Ordonnansie no. 5 van 1902, ter regulering van vrywilligerkorpse in Transvaal, gepromulgeer. Hierin is aan die goewerneur van Transvaal onder meer mag verleen om vrywilligerkorpse op te rig of te ontbind en om regulasies vir die funksionering daarvan op te stel.

Teen hierdie tyd het die onderhoud van die 3.000 perde wat as 'n geskenk van die Imperiale regering ontvang is, 'n ernstige probleem laat ontstaan. Vanweë die groot skaarste aan voer na die oorlog sou die Transvaalse regering die perde alleen teen 'n hoë koste kon aanvaar. Daar is gevolglik besluit dat die perde wat nie voor die einde van September 1902 deur die toekomstige korpse self oorgeneem kon word nie, finaal aan die Britse militêre owerhede teruggegee moes word. Die korpse was nie verplig om ál 3.000 perde oor te neem nie, maar slegs soveel as waarvoor die regering kans gesien het om verantwoordelikheid voor te aanvaar. 
Aangesien daar geen regulasies was waarvolgens die korpse kon funksioneer nie, kon die Transvaalse regering, weens gebrek aan geldelike middele, nie in die onderhoud van die perde voorsien nie. Sekere invloedryke persone wat in die vrywilligerorganisasie belang gestel het, maar wie se name ongelukkig onbekend is, het onderneem om op eie inisiatief soveel moontlik van die perde oor te neem en om sover moontlik in hulle onderhoud te voorsien.

Die gedagte het inmiddels ontstaan om al die perde van die Britse militêre owerheid oor te neem, hulle te verkoop en met die geld 'n fonds te stig. Hierdie fonds kon dan op 'n latere tydstip, wanneer die korpse behoorlik gestig sou wees, aangewend word om vir hulle perde te koop. Hulle wat verantwoordelikheid vir die onderhoud van die perde aanvaar het, het ewenwel so 'n optrede nie as behoorlik ten opsigte van 'n geskenk beskou nie. Omdat hierdie weldoeners die perde op gewone weiveld laat wei het, was daar gevolglik 'n betreklike groot verlies.

Ten einde 'n maksimum benutting van die Imperiale geskenk te verseker, het die opstel van regulasies waarvolgens vrywilligerkorpse in Transvaal sou funksioneer, teen die begin van Augustus 1902 dringend geword.

Inmiddels is tot die gevolgtrekking gekom dat in Ordonnansie no. 5 van 1902 maar gebrekkig voorsiening gemaak is vir die praktiese funksionering van 'n permanente vrywilligermag. Daar is onder meer nie vir die toevoeging van Staande Mag-personeel tot vrywilligerkorpse en ook nie vir die daarstelling van 'n reserwemag voorsiening gemaak nie. Die grootste tekortkoming was egter die gebrekkige voorsiening vir die handhawing van dissipline wanneer korpse op aktiewe of militêre diens sou gaan.

Teen Augustus 1902 was dit, op grond hiervan, duidelik dat onmiddellike en dringende aandag aan die praktiese aspekte vir die daarstelling van 'n permanente Transvaalse verdedigingsmag geskenk sou moes word.

Vir die Britse militêre owerheid was daar een netelige vraag, nl. of Boere ook tot die vrywilligermag toegelaat moes word. Uit die aard van die saak kon hierdie aangeleentheid op dié tydstip toe die mag georganiseer is, nie in die openbaar genoem word nie.

Onthou sal word dat die Rand Rifles, wat eers in Oktober 1902 ontbind is, feitlik uit Engelstaliges bestaan het. Omdat hierdie vrywilligerorganisasie toentertyd as oorlogsmaatreël tot stand gekom het, was die nasionaliteitsgrondslag daarvan selfsprekend.

$\mathrm{Na}$ die oorlog was die toestand heeltemal anders. Alle Britse onderdane in Transvaal moes, vir die doeleindes van aansluiting by 'n algemene vrywilligerorganisasie vir die kolonie, as gelykwaardig beskou word.

Sowel Chamberlain as Milner was bewus van 'n potensiële opstandigheid onder die Boere. Milner was trouens oortuig dat die Boere mettertyd, as die geleentheid hom sou voordoen, sou trag om die Britse juk af te skud. Hierdie vrees by die Britse owerheid is weerspieël in die volledige ontwapening van die Boere na die oorlog, in die strenge bepalings met betrekking tot die besit van vuurwapens en ammunisie, maar was veral geleë in die feit dat Milner nie bereid was om skietverenigings na plattelandse gebiede te laat uitbrei nie. In Oktober 1902 het hy wel toestemming verleen dat ses skietverenigings aan die Witwatersrand mag voortbestaan. Betekenisvol is dit dat laasgenoemde skietverenigings uit die organisasie van die Rand Rifles ontstaan en bygevolg 'n oorwegend Engelssprekende ledetal gehad het.

Om die Boere tot die vrywilligerbeweging toe te laat, sou beteken dat hulle onmiddellik weer bewapen word. Dit was egter duidelik dat die Boerebevolking nie op regsgronde lidmaatskap aan 'n algemene vrywilligerorganisasie geweier kon word nie. 
Milner se oplossing vir hierdie vraagstuk was tweeledig, nl. eerstens om die mag organisatories so tipies Brits te maak dat dit nie die Boerebevolking se belangstelling sou wek nie en verder om die geldelike bydrae van die regering redelik klein te hou, sodat die grootste gedeelte van die instandhouding van die korpse deur die vrywilligers self gedra moes word.

Milner het geweet dat die geldmag in Suid-Afrika na die oorlog grootliks tot Britse kringe beperk was. Verder het hy gehoop dat die Boere vir minstens 'n aantal jare na die oorlog finansieël nie kragtig genoeg sou wees vir aansluiting by die vrywilligerkorpse nie.

Die uitgangspunt om die Boerebevolking aan die begin nie by die verdedigingsmag van die kolonie in te skakel nie, was daarvoor verantwoordelik dat die mag aanvanklik slegs tot die Witwatersrandse gebied beperk was. Die rede hiervoor was dat die Witwatersrandse bevolking grotendeels bestaan het uit dié Uitlanders wat aan die begin van die oorlog die Transvaal verlaat het en toe die gevaar verby was, hulle weer rustig as lojale Britse onderdane in die gebied kom vestig het. Anders as wat met die plattelandse Boerebevolking die geval was, het die Transvaalse regering dus aan die Witwatersrand 'n gekonsentreerde en lojale bevolking gehad.

In verband met die praktiese organisasie van die Transvaalse verdedigingsmag het Milner begin om, aan die einde van Junie of aan die begin van Augustus 1902, onder voorsitterskap van genl.-maj. Oliphant, M.V.O., 'n vergadering in Johannesburg, te belê. Op hierdie vergadering het onder meer die volgende belangrike aspekte die aandag geniet: Die wenslikheid om die vrywilligermag vir administratiewe doeleindes onder die Britse opperbevelhebber in Suid-Afrika te laat ressorteer; die algemene vraagstuk van finansiering van so 'n mag, m.a.w. die verhouding van die verantwoordelikheid wat deur die regering en die korpse onderskeidelik aanvaar moes word; en die beskikking oor die perde wat as geskenk van die Imperiale regering ontvang is. Tydens die vergadering is besluit om 'n komitee te benoem om oor die voorgaande aspekte te besin en om regulasies vir die funksionering van vrywilligerkorpse op te stel.

Hierdie komitee het op 11 Augustus 1902 in die kantoor van die Hoë Kommissaris met sy werksaamhede begin. Die uitvloeisel van hierdie komitee se werksaamhede was dat dit 'n aanvanklike organisasie vir die vrywilligermag by die owerheid aanbeveel het. Die owerheid het dit aanvaar. Verder het hulle die regulasies vir die funksionering van vrywilligerkorpse opgestel.

Tydens sy sitting van 9 tot 10 September 1902 het die Transvaalse Uitvoerende Raad die konsep-regulasies wat deur die komitee voorgestel is in beginsel aanvaar en net 'n paar voorstelle aangaande kleiner wysigings na die komitee terugverwys.

Op 27 Oktober 1902 is Ordonnansie 33/1902, waarkragtens vrywilligerkorpse in Transvaal daadwerklik ingestel kon word, gepromulgeer. Op 31 Oktober 1902 is hierdie ordonnansie die eerste keer in die Staatskoerant gepubliseer. Op 4 November 1902 is die regulasies waarkragtens die korpse kon funksioneer, eweneens gepromulgeer. Laasgenoemde is die eerste keer op 7 Novevmber in die Staatskoerant gepubliseer.

In Oktober 1902 het Milner van die War Office verneem dat die Imperiale regering toegestem het om 'n skenking van gewere en bybehorende toerusting vir 10.000 infanterie-vrywilligers aan die Transvaalse regering uit te reik. Die skenking was aan dieselfde voorwaardes as dié vir dié 3.000 berede vrywilligers onderhewig Die 6.000 gewere en bybehorende toerusting wat Kitchener gedurende die AngloBoere-oorlog gratis aan die Rand Rifles uitgereik het, is as deel hiervan beskou. Milner het ook aansoek gedoen om 'n skenking van uniforms vir 10.000 infanterievrywilligers, maar hierdie versoek is van die hand gewys. 
Met die totstandkoming van die Transvaalse vrywilligermag in sig, is die Rand Rifles met ingang van 10 Oktober 1902 ontbind. Vanaf vroeg in Desember 1902 het werwing vir die eerste vrywilligerkorpse van die Transvaal-kolonie 'n aanvang geneem.

Goewermentskennisgewing no. 688 van 12 Desember 1902 moet as die amptelike geboortesertifikaat van die Transvaal-kolonie se verdedigingsmag beskou word. Die toepaslike gedeelte van die betrokke kennisgewing lui soos volg:

\section{GOVERNMENT NOTICE NO. 688 OF 1902.}

In accordance with section 2 of the Volunteer Corps Ordinance, 1902, His Excellency the Lieutenant-Governor has been pleased to approve of the formation of the following regiments of Volunteers:

a. Mounted Corps.

1. Imperial Light Horse (Right Wing).

2. Imperial Light Horse (Left Wing).

3. South African Light Horse.

4. Johannesburg Mounted Rifles.

5. Scottish Horse.

b. Infantry and Engineer Corps.

1. Central South African Railway Volunteers.

2. Transvaal Light Infantry.

3. Transvaal Scottish Volunteer Regiment.

Die mag wat sodoende tot stand gekom het, het in die omgang as die Transvaal Volunteers of die Transvaal Volunteer Corps bekendgestaan. 


\section{ORGANISASIE EN ONTWIKKELING VAN DIE "TRANSVAAL VOLUNTEERS" ONDER KROONKOLONIEBESTUUR}

Een van die probleme by die organisasie van die Transvaal Volunteers (T.V.) was die vraag of dit onder die Britse opperbevelhebber in Suid-Afrika en die War Office of onder die Transvaalse siviele regering en die Colonial Office sou ressorteer.

Terwyl hy in Suid-Afrika was, was Kitchener ten gunste van eersgenoemde beheerstelsel, terwyl Milner laasgenoemde stelsel verkies het.

Die finale besluit was dat die T.V. deur die siviele regering van Transvaal beheer sou word. Die opperbevel het in die luitenant-goewerneur van Transvaal gesetel. Hierdie amptenaar was statutêr gemagtig om vrywilligerkorpse op te rig, te ontbind en om vrywilligers vir sowel aktiewe en militêre diens op te roep, die aanstelling en ontslag van offisiere te behartig en regulasies vir die funksionering van die T.V. uit te reik.

Die Assistent-Adjudant-generaal was regstreeks aan die Luitenant-Goewerneur vir die militêre organisasie en administrasie van die T.V. verantwoordelik. Hierin is hy bygestaan deur ' $n$ permanente staf wat grotendeels bestaan het uit offisiere en onderoffisiere wat uit Britse militêre geledere aangestel is.

Die permanente staf van die T.V. het uit die Assistent-Adjudant-generaal en sy hoofkwartierstaf vir die hele T.V. bestaan. Aan die vrywilligerkorps is een adjudant en 'n aantal sersant-instrukteurs toegevoeg. Die aantal sersant-instrukteurs is deur die sterkte van die onderskeie korpse bepaal.

Die Assistent-Adjudant-generaal en die permanente staf is deur die siviele regering van Transvaal aangestel en besoldig. Ten einde noue samewerking tussen die Transvaalse vrywilligermag en die Britse gereelde troepe in Suid-Afrika te verseker, is hierdie offisier en sy hoofkwartier tot die personeel van die Britse opperbevelhebber in Suid-Afrika toegevoeg.

Omdat die Assistent-Adjudant-generaal deur die Transvaalse regering besoldig is, het die Britse opperbevelhebber in Suid-Afrika in Desember 1903 beslis dat dit nie beskou kon word dat hierdie offisier die pos van Assistent-Adjudant-generaal in die Britse leër beklee nie. Vanweë die feit dat die benaming van die pos hierdie indruk gewek het, het hy voorgestel dat dit na Chief Staff Officer Transvaal Volunteers of Commandant Transvaal Volunteers verander moet word. Vanaf 15 Januarie 1904 is die ampsbenaming van die bevelvoerende offisier van die Transvaal Volunteers dan ook na The Commandant of the Transvaal Volunteers verander.

Die posisie van die bevelvoerende offisier van die Transvaal Volunteers in die beheerstruktuur van die T.V. is gedurende 1906 in die vorm van regulasies vasgelê. $\mathrm{Hy}$ is aan sowel die Luitenant-Goewerneur van Transvaal as aan die Britse opperbevelhebber in Suid-Afrika vir die beheer en administrasie van die Mag verantwoordelik gestel.

Die bevelvoerende offisier van die onderskeie vrywilligerkorpse was regstreeks aan die kommandant van die Transvaal Volunteers vir die beheer en administrasie van hulle korpse verantwoordelik. 
Kragtens Goewermentskennisgewing no. 688 van 12 Desember 1902 is vyf beredeen drie infanterie- en geniekorpse ingestel. Die berede korpse was: Die Imperial Light Horse (Right Wing), die Imperial Light Horse (Left Wing), die South African Light Horse, die Johannesburg Mounted Rifles en die Scottish Rifles. Die volgende infanterie- en geniekorpse het tot stand gekom: Die Central South African Railway Volunteers, die Transvaal Light Infantry en die Transvaal Scottish Volunteer Regiment.

Daar is ongelukkig nie veel oor die werwingsgebied van hierdie korpse bekend nie. Wat wel met sekerheid gekonstateer kan word, is dat, met uitsondering van die Imperial Light Horse (Left Wing), waarvan die hoofkwartier op Potchefstroom was, alle ander berede korpse toegelaat is om in die Witwatersrandse gebied lede te werf. Die Central South African Railway Volunteers was tot spoorwegwerknemers van die Transvaal- en Oranjerivier-kolonie beperk. Die ander twee infanteriekorpse het slegs rekrute in die Witwatersrandse gebied gewerf.

Uitbreiding van die T.V. het spoedig na die instelling daarvan gevolg. Reeds in Maart 1903 is die noodsaaklikheid van 'n mediese eenheid besef. Bygevolg is die Transvaal Medical Staff Corps op 20 Maart 1903 ingestel. Dié korps het uit vier kompanies bestaan, met 'n goedgekeurde personeelsterkte van een luitenant-kolonel as bevelvoerder, twaalf kompanie-offisiere, vier kwartiermeesters, vier eersteklasstafsersante, agt tweedeklas-stafsersante, sestien sersante, twee-en-dertig korporaals, 315 weermanne en agt beulblasers. Die maksimum en minimum sterktes is op 400 en 200 man vir alle range vasgestel.

Hoewel die korpshoofkwartier in Johannesburg was, is die mediese korps toegelaat om in alle Transvaalse distrikte te werf.

Aan die Witwatersrand was daar duisende mynwerkers wat nie so maklik by berede korpse kon inskakel nie. As infanteriste kon hulle wel 'n waardevolle bydrae tot die beskerming van die myne lewer om op dié wyse die tradisie van die eertydse Rand Rifles voort te sit. Ter benutting van hierdie beskikbare mannekrag is 'n infanteriekorps, die Witwatersrand Rifles, op 1 Mei 1903 ingestel. Dié korps het uit agt kompanies bestaan, met sy hoofkwartier in Johannesburg. Die goedgekeurde sterkte was by benadering 1.200 man. Die kompanies van die Witwatersrand Rifles was soos volg oor die Witwatersrandse gebied versprei: New Modderfontein, New Kleinfontein, Boksburg, Germiston, East Central, Robinson Mine, Luipaardsvlei, Roodepoort en Randfontein.

Die sterkte van die korps het teen die einde van Junie 1904 op 469 man te staan gekom. Na berekening was $25 \%$ vroeëre lede van die Rand Rifles. Verder was die korps grotendeels uit lede van die vroeëre Railway Pioneer Corps saamgestel.

Enkele dae na die instelling van die Witwatersrand Rifles het die Transvaalse vrywilligerbeweging ook na Pretoria uitgebrei, toe die Northern Rifles (N.R.) op 15 Mei 1903 aldaar gestig is.

Die ontstaansgeskiedenis van die Northern Rifles kan teruggevoer word na April 1902. Genl.-maj. Barton, die toenmalige bevelvoerende offisier van die militêre distrik Pretoria, is gedurende hierdie maand deur Kitchener gemagtig om met die oprigting van 'n vrywilligerkorps in Pretoria te begin. Dié korps sou uit 'n berede-, 'n fietsryers- en 'n infanterieafdeling bestaan het.

Lede van die N.R. is vir 'n tydperk van ses maande gewerf. Teen die einde van September 1902 sou die korps dus ontbind moes word. Die naderende einde van die militêre regime in Transvaal het aanleiding daartoe gegee dat die bevelvoerder van die korps, maj. D. W. Bruce, reeds teen die einde van Mei 1902 met die siviele 
regering van Transvaal in verbinding getree het oor die toekoms van die korps in vredestyd. Maj. Bruce wou vasstel of die korps op 'n permanente grondslag by die toekomstige vrywilligermag van die Transvaal ingeskakel kon word. Die Transvaalse regering het egter nie dadelik op sy navraag gereageer nie.

Op 11 Augustus 1902 het die bevelvoerder van die Northern Rifles weer eens met die Transvaalse Koloniale Sekretaris in verbinding getree oor die permanente voortbestaan van sy korps. Hierdie keer het die Koloniale Sekretaris by die goewerneur aanbeveel dat die dienste van die Pretoriase vrywilligerkorps as permanente vrywilligerkorps, ooreenkomstig die bepalings van Ordonnansie no. 5 van 1902, aanvaar moes word.

Die komitee wat deur Milner aangestel is om die praktiese organisasie van die permanente vrywilligermag te bepaal en regulasies daarvoor op te stel, was toe net in sitting. Gevolglik is die bevelvoerende offisier van die Pretoriase vrywilligerkorps uitgenooi om lid van die komitee te word. Indien hy nie lid van die komitee word nie kon hy sy voorstelle deur die Militêre Sekretaris van die Hoë Kommissaris aan die Komitee voorlê.

Hoewel 'n verslag van genoemde komitee se werksaamhede ontbreek, wil dit uit latere korrespondensie voorkom asof die komitee op 'n stadium besluit het om drie regimente in Pretoria op te rig, t.w. 'n berede korps, moontlik as 'n gedeelte van die Kitcheners Fighting Scouts, 'n korps vir werknemers van die spoorweë en 'n infanterieregiment.

Dit wil verder voorkom asof hierdie eenhede ondertussen aktief begin werf het en dat die berede regiment sy gedeelte van die Imperiale geskenk van perde reeds voor November 1902 in ontvangs geneem het.

Vroeg in November 1902 het die Transvaalse owerheid egter besluit om nie 'n volwaardige berede regiment onder die benaming Kitcheners Fighting Scouts in Pretoria op te rig nie. Aan vrywilligers in Pretoria wat daarin belang gestel het om as berede vrywilligers tot die permanente vrywilligerorganisasie toe te tree, is 'n keuse gelaat om 'n eskadron van òf die South African Light Horse òf die Imperial Light Horse te vorm. Verder is besluit dat die Pretoriase vrywilliger-organisasie vir spoorwegamptenare by die Central South African Railway Volunteers ingeskakel sou word. Vir infanteriedoeleindes sou Pretorianers onder die benaming 2nd Transvaal Light Infantry by die Transvaal Light Infantry inskakel.

Vroeg in Desember 1902 het die Luitenant-Goewerneur van Transvaal beslis dat daar geen infanteriekorps in Pretoria opgerig sou word nie. Die Kitcheners Fighting Scouts en die Railway Pioneer Regiment is onderskeidelik volgens goewermentskennisgewing no. 523 van 1903 op 1 Februarie 1903 en 30 April 1903 amptelik ontbind.

'n Afsonderlike vrywilligerkorps is hierna op 15 Mei 1903 onder die benaming Northern Rifles vir Pretoria en die gelyknamige distrik ingestel. Die gemagtigde sterkte vir die N.R. was vier berede eskadrons, vier infanteriekompanies en een kompanie fietsryers. Die hoofkwartier van hierdie saamgestelde korps was Pretoria, met Pietersburg en Middelburg as buiteposte.

Die Luitenant-Goewerneur van Transvaal, sir Arthur Lawley, K.C.M.G., is as erekolonel van die korps benoem, terwyl kapt. Geoffrey Carr Glyn, D.S.O., as eerste bevelvoerder en kapt. Maurice L. Pears, van die Scottish Horse, as eerste adjudant aangestel is.

In sy verslag vir die jaar geëindig 30 Junie 1903 kon die kommandant van die Transvaal Volunteers reeds rapporteer dat hy besig was om met die Algemene Bestuurder van die Central South African Railways oor die oprigting van 'n transportkorps te onderhandel. Dié korps sou uit lede van die C.S.A.R. bestaan. 
Die Volunteer Transport Corps is met ingang van 1 Julie 1903 met die volgende gemagtigde personeelsterkte ingestel: Een kaptein, vier luitenante, een kompaniesersant-majoor, een kompanie-kwartiermeester-sersant, vyf sersante, nege korporaals, twaalf vakmanne en 400 kleurlingdrywers. Die korpshoofkwartier was in Johannesburg.

Volgens ooreenkoms met die Central South African Railways sou hierdie instansie te eniger tyd die personeel van die transportkompanie, 100 waens en 1000 muile aan die Transvaalse vrywilligermag voorsien wanneer laasgenoemde dit sou benodig. In geval van mobilisasie kon hierdie kompanie die kern van 'n groter transportkorps vorm.

Nieteenstaande die feit dat Ordonnansie no. 33 van 1902 nie vir die instelling van artilleriekorpse voorsiening gemaak het nie, het die Transvaalse Luitenant-Goewerneur tog op 17 Maart 1904 so 'n korps ingestel. Vir 'n geruime tyd na die instelling daarvan het die korps as die Lys Volunteer Corps, só genoem na sy stigter en eerste bevelvoerder, maj. Robert Oliver Godfrey Lys, bekend gestaan. Dié korpshoofkwartier was in Johannesburg, en die aanvanklike personeelsterkte daarvan was soos volg: 'n Majoor as bevelvoerder, een kaptein, vyf luitenante, een adjudant, een sersantinstrukteur, een ordonnans, een stoorman, een battery-sersant-majoor, een batterykwartiermeester-sersant, twee beuelblasers, agt sersante, agt korporaals, agt bombardiers, agt waarnemende bombardiers, twee-en-sestig kanonniers, vyf seiners en drie afstandmeters, verder een sersant-hoefsmid, een korporaal-hoefsmid, ses gewone hoefsmede, een sersant- of korporaal-wamaker, een sersant- of korporaalhaltermaker en dertig drywers (Suid-Afrikaanse Bantoes). Vir bewapening sou die korps een battery $12 \frac{1}{2}$-ponder snelvuurkanonne en een seksie van twee eenponder snelvuur-Vickers-Maxim-kanonne kry. Met ingang van 1 September 1904 is die benaming van die Lys Volunteer Corps na die van The Transvaal Horse Artillery verander.

Met ingang van 14 September 1904 is die Volunteer Company of Military Signallers, met 'n goedgekeurde sterkte van een kaptein, sestien korporaals en ses-en-sewentig weermanne ingestel. Deur die instelling van hierdie kompanie is verseker dat voldoende seiners in geval van mobilisasie beskikbaar sou wees. Meer seiners sou hierdeur opgelei kon word as onder die stelsel waarvolgens elke korps 'n paar seiners moes oplei.

Teen die einde van 1904 is verder slegs kleiner organistoriese veranderinge in die T.V. aangebring. So is die Krugerdorpse eskadron van die Imperial Light Horse (Left Wing) met ingang van 1 November 1904 na die Imperial Light Horse (Right Wing) oorgeplaas. Verder is die Medical Staff Corps gedurende Desember 1904 van vier tot vyf kompanies vergroot. Die totale goedgekeurde sterkte van hierdie korps was nou 500 vir alle range. Die goewerneur het terselfdertyd goedkeuring verleen vir die oprigting van 'n verpleegstersreserwe, bestaande uit een matrone en twaalf susters.

Aan die begin van 1905 is begin met die oorskakeling van die T.V. na 'n distriksorganisasie. Deur die toepassing van hierdie beleid sou oorvleuelende werwingsgebiede in die meeste gevalle uitgeskakel word. Dit het die volgende ingrypende organisatoriese veranderinge tot gevolg gehad: 'n Korps, genaamd The Eastern Rifles, bestaande uit ses berede eskadrons en drie infanteriekompanies, is op 1 Januarie 1905 ingestel. Die hoofkwartier van die korps was Standerton en die werwingsgebied Oos-Transvaal.

Die Heidelbergse eskadron van die South African Light Horse, die Standertonse eskadron van die Johannesburg Mounted Rifles, en die Barbertonse afdeling van die Northern Rifles is by die Eastern Rifles ingelyf. 
'n Korps, genaamd The Western Rifles, bestaande uit ses berede eskadrons en drie infanteriekompanies, is ook vanaf 1 Januarie 1905 ingestel met Potchefstroom as hoofkwartier en Wes-Transvaal as werwingsgebied.

Die Imperial Light Horse (Left Wing) en die Potchefstroomse afdeling van die Transvaal Scottish Volunteers is by die Western Rifles ingelyf. Omdat die Imperial Light Horse (Left Wing) by die Western Rifles ingelyf is, is die naam van die Imperial Light Horse (Right Wing) vanaf 1 Januarie 1905 na Imperial Light Horse verander.

Die omskrewe werwingsgebiede vir die Transvaal Volunteers wat vanaf 1 Januarie 1905 ingestel is, was: die Witwatersrand, met hoofkwartier in Johannesburg (dit het gestrek van Springs tot Randfontein en het die Krugersdorpse landdrosdistrik ingesluit); Noord-Transvaal, met hoofkwartier in Pretoria (dit het die distrikte en dorpe Pretoria, Middelburg, Lydenburg, Soutpansberg en Waterberg ingesluit); Oos-Transvaal, met hoofkwartier in Standerton (dié gebied het die distrikte en dorpe Heidelberg, Standerton, Wakkerstroom, Piet Retief, Ermelo, Carolina en Swaziland ingesluit); Wes-Transvaal, met hoofkwartier in Potchefstroom. Dié gebied het die dorpe en distrikte Potchefstroom, Wolmaransstad, Lichtenburg, Marico en Rustenburg ingesluit.

Alle korpse, behalwe die Northern, Eastern en Western Rifles, is toegelaat om in die distrik Witwatersrand werwing te verrig. Die volgende korpse, t.w. Central South African Railway Volunteers, die Transvaal Volunteer Medical Staff Corps, die Volunteer Transport Corps, die Veterinary Corps en die Supply Corps kon in alle distrikte werf. Die Northern Rifles, Eastern Rifles en Western Rifles was, wat werwingsgebiede betref, onderskeidelik tot die militêre distrikte Noord-, Oos-, en Wes-Transvaal beperk.

Hierna was daar, tot by die instelling van verantwoordelike bestuur (1906), geen radikale verandering nie maar wel kleiner veranderings soos die volgende: Op 1 Januarie 1905 is 'n telegrafistekompanie ingestel wat tot die Transvaal Light Infantry Volunteers toegevoeg is. Vanaf 1 Julie 1905 is die Transvaal Volunteer Medical Staff Corps uitgebrei deur die toevoeging van 'n berede afdeling met 'n sterkte van een offisier, twee korporaals en nege-en-twintig weermanne; 'n fietsryerseksie met 'n sterkte van een offisier, een stafsersant, een sersant, twee korporaals en agt-entwintig weermanne en twee gekwalifiseerde aptekers per kompanie. Hulle sou as sersante aangestel word en ten aansien van die goedgekeurde sterkte bótallig wees.

'n Bykomende kompanie van die Central South African Railway Volunteers, genaamd No. IX Company, met hoofkwartier te Standerton, is op 20 November 1905 ingestel. 'n Korps genaamd The Transvaal Cycle Corps, is op 1 Oktober 1905 met 'n goedgekeurde sterkte van een-en-dertig offisiere en 451 ander range ingestel. Gedurende Februarie 1906 is die goedgekeurde sterkte van die Western Rifles van ses eskadrons en drie kompanies na sewe eskadrons en een kompanie verander.

'n Waardevolle uitbreiding het ook gedurende Februarie 1906 plaasgevind, toe 'n posduifafdeling as ' $n$ integrerende deel van die Transvaal Light Infantry ingestel is.

Daar kan met reg beweer word dat die Transvaal Volunteers tot aan die einde van die kroonkoloniebestuur organisatories tot 'n goed gedifferensieerde mag ontwikkel het. Of dit wel tot 'n doeltreffende gevegsmag ontwikkel het, is 'n ander aspek wat in die volgende hoofstuk noukeuriger nagegaan word.

Voldoende kamp- of mobilisasietoerusting is 'n voorvereiste vir enige verdedigingsmag om 'n doeltreffende gevegsmag te kan ontwikkel. Hierdie toerusting is eerstens onontbeerlik vir oefenkampe waar militêre opleiding geskied. Verder is mobilisasie vir oorlog sinneloos daarsonder. 
Tot 1905 was die posisie van die Transvaal Volunteers as verdedigingsmag vir die Transvaal-kolonie hoogs onbevredigend. Daar is jaarliks sowat $£ 150.000$ aan die instandhouding van die orginisasie bestee. Weens gebrek aan kamp- of mobilisasietoerusting en ammunisie was die T.V. egter nie in staat om in tye van nood sonder hulp van buite te mobiliseer nie. Die uitgawes vir die verskaffing van mobilisasietoerusting vir die hele mag sou nie deur die Transvaalse regering bekostig kon word nie. Die kommandant van die Transvaal Volunteers het toe, in hierdie verband, die volgende voorstelle aan die regering voorgelê: Aangesien dit onwaarskynlik was dat die hele mag gelyktydig opgeroep sou word, moes slegs voorsiening gemaak word vir mobilisasietoerusting vir dié deel van die mag wat waarskynlik op een slag opgeroep kon word. Dit is op 3.000 gestel, nl. 1.800 berede manskappe, 600 infanteriemanskappe en 600 departementele troepe.

Vir die res van die T.V. kon, indien nodig, mobilisasietoerusting van die imperiale militêre owerheid in Suid-Afrika in bruikleen verkry word. Die Transvaalse regering moes verdere reserwe ammunisie vir die hele mag aankoop. Vir hierdie doel moes die totale sterkte van die T.V. op 8.000 gestel word.

Die berekende uitgawe vir die voorsiening van mobilisasietoerusting vir 3.000 man en reserwe-ammunisie vir die hele mag was: Ammunisie vir die hele mag: $£ 9.300$; mobilisasietoerusting vir drie mobiele kolonnes (artillerie uitgeslote): $£ 6.700$ en oprigting van magasyne vir die opberging van toerusting en ammunisie: $£ 2.000$. 'n Totaal dus van $£ 18.000$.

Uitvoerende Raadsbesluit no. 533 van 5 April 1905 was 'n mylpaal in die geskiedenis van die Transvaal Volunteers. Kragtens hierdie besluit is $£ 15.600$ vir die voorsiening van mobilisasietoerusting en ammunisie vir die mag gestem. Die bedrag sou soos volg bestee word: Ammunisie vir die hele mag: $£ 7.600$, toerusting vir drie mobiele kolonnes (artillerie uitgeslote): $£ 8.000$, dus in totaal $£ 15.600$.

Alhoewel die bedrag uit verwagte en doelbewuste besparings uit die vrywilligerbegrotingspos toegesê is, staan dit vas dat dit eers na die toepassing van hierdie besluit vir die Transvaalse regering moontlik was om die vrywilligers na willekeur vir diens op enige plek in Suid-Afrika te kon mobiliseer.

Die doeltreffendheid van 'n verdedigingsmag is grootliks afhanklik van sy bewapening. Die waarde van die Transvaal Volunteers as verdedigingsorganisasie kan dan ook nagegaan word aan die hand van sy bewapening.

Vrywilligers is van die begin af met .303 Lee Metford- en Lee Enfield-gewere uitgerus. Uit die aard van die aanvanklike samestelling van die mag was gewone gewere eintlik die belangrikste krygstuig. Die aantal masjiengewere het egter geleidelik toegeneem.

Aan die begin van die kroonkolonie-tydperk het die mag oor slegs vyf masjiengewere beskik. Teen die einde van die onderhawige periode is die aantal masjiengewere na een-en-twintig vermeerder. Elf hiervan is deur die Transvaalse regering aangekoop. Gedurende 1905 is nege masjiengewere as deel van die mobilisasietoerusting verkry. Vier masjiengewere is in bruikleen van die Imperiale regering ontvang, terwyl ses deur private maatskappye, hoofsaaklik mynmaatskappye, aan die mag geskenk is.

Ten tye van die organisasie van die Transvaal Volunteers het die Imperiale regering drie 12-ponder vlootkanonne in bruikleen aan die Central South African Railway

Volunteers beskikbaar gestel. Hierdie kanonne is op gepantserde treine gebruik. 
Met die instelling van die artilleriekorps, gedurende Maart 1904, was daar nog geen kanonne beskikbaar nie. Die Britse militêre owerheid in Suid-Afrika het egter twee ondienstige artillerie-kanonne vir opleidingsdoeleindes tot beskikking van die artillerie-vrywilligers gestel.

In sy verslag oor die jaar geëindig 30 Junie 1906 kon die kommandant van die mag rapporteer dat die Britse opperbevelhebber in Suid-Afrika ses 15-ponder agterlaaierkanonne in bruikleen aan die vrywilligers beskikbaar gestel het.

Teen die einde van Maart 1906 het die Transvaalse regering besluit om onmiddellik vier van die jongste modelle 13-ponder snelvuurkanonne vir die artilleriekorps te bestel. In Mei 1906 is verder besluit om op die begroting van 1906/1907 voorsiening te makk vir die aankoop van twee 1-ponder snelvuurkanonne (pom-poms), met affuite en voorwaens, ook vir gebruik deur die artilleriekorps.

Vanweë van die feit dat die War Office meegedeel het dat die 1-ponder snelvuurkanonne (pom-poms), in Indië op die proef gestel is en nie geslaagd bevind is nie, het die Transvaalse regering besluit om liewers twee 1-ponder outomatiese snelvuurVickers-Maxim-kanonne te bestel.

In Mei 1906 is verder besluit om 2.000 Martini-Henry-gewere en 500.000 bybehorende patrone teen $£ 2$ per geweer en $£ 4$ per 1.000 patrone, van die Kaapse regering te koop. 


\section{4 \\ DIE ZOELOE-OPSTAND VAN 1906}

Vroeg in 1906 het die Zoeloe-opstand in Natal uitgebreek. Uit 'n militêre oogpunt beskou, was dit 'n belangrike gebeurtenis: Eerstens omdat hieruit die eerste daadwerklike poging tot interkoloniale militêre samewerking tussen die Brits-Suid-Afrikaanse kolonies voortgekom het, verder omdat dit aan die Transvaal Volunteers 'n geleentheid tot mobilisasie gebied het.

Die waarde van die Transvaal Volunteers as doeltreffende gevegsmag kon nou prakties bepaal word.

Teen die einde van 1906 was daar wydverspreide onrus wat grootliks te wyte was aan ontevredenheid onder die Zoeloes oor die naturellebeleid van die Natalse regering.

Die regstreekse aanleiding tot openlike opstand was die feit dat die Natalse parlement, vanweë 'n nypende geldtekort, gedurende Augustus 1905 'n hoofbelasting van $£ 1$ per kop ingestel het. Dit was op alle manlike inwoners, met uitsluiting van ingeboekte Indiërs en getroude Bantoes, van toepassing. Dié heffing met die sensus van 1904, het die stambantoe agterdogtig en aggressief gestem.

In Augustus 1905 het die Natalse Minister van Naturellesake aan landdroste opgedra om stamhoofde en hoofmanne byeen te roep om die bepalings van die wet aan hulle te verduidelik. Byeenkomste is vir September en Oktober 1905 belê. Tydens dié byeenkomste het die Zoeloes se opstandigheid oor die nuwe belasting al duidelik na vore gekom.

Die wet het van 1 Januarie 1906 af in werking getree en die belasting moes op 20 Januarie 1906 of so spoedig moontlik daarna geïn word. 'n Bantoe kon egter nie skuldig bevind word aan oortreding van die wet voor na 31 Mei 1906 nie.

Die erns van die Zoeloe-ontevredenheid is besef toe die onderdane van hoofman Mveli te Henley, sowat sewentien $\mathrm{km}$. van Pietermaritzburg, gewapende teenstand gebied het toe die landdros van Umgeni op 7 Februarie 1906 die belasting aldaar wou invorder. 'n Dag later is 'n klein polisiemag na Henley gestuur om dié wat nie wou betaal nie, te arresteer. Twee lede van hierdie mag is om die lewe gebring, terwyl die res moes vlug.

By die Natalse regering was daar teen hierdie tyd geen twyfel meer oor die erns van die toestand nie, en teen 9 Februarie 1906 is die Natalse milisie gemobiliseer om die opstand te onderdruk. Krygswet is op 10 Februarie in die hele kolonie afgekondig.

Op 10 Februarie 1906 het een kolonne, onder kol. sir Duncan McKenzie, C.B., K.C.M.G., J.P., V.D., van die Natal Carbineers, na Mveli se kraal vertrek en met die opstandelinge afgereken. Opstandigheid oor die betaling van die hoofbelasting het egter geruime tyd lank onder die verskillende stamme van die distrik Ixopo en ander stamme langs die suidkus geheers. Vanaf 19 Februarie het kol. D. McKenzie se kolonne in hierdie gebiede magsdemonstrasies gelewer. Deur die blote teenwoordigheid van troepe en die ferme optrede van kol. McKenzie is die orde spoedig herstel. Op 30 Maart 1906 is sy kolonne gedemobiliseer. 
Ook in die distrik Mapumulo het die onderdane van verskeie stamme die gesag van die landdros verontagsaam toe hy die nuwe belasting wou invorder.

Op 24 Februarie is 'n kolonne onder kol. G. Leuchars gemobiliseer. Hierdie kolonne moes die landdros van Mapumulo tydens die vervolging van opstandelinge in sy distrik bystaan. Ook kol. Leuchars se ferme optrede het die opstandigheid alhier spoedig laat verdwyn. Reeds op 16 Maart 1906 is sy kolonne gedemobiliseer.

Die eerste fase van die opstand was dus teen die einde van Maart 1906 verby.

Vroeg in April 1906 het die tweede, ernstiger fase van die opstand begin, toe Bambata, 'n minder belangrike hoofman van die distrik Greytown, sy landdros teengestaan het en met sy volgelinge oor die Tugela tot in die Nkandhlawoud getrek het.

In Transvaal is besef dat, indien die Zoeloe-opstand nie in die kiem gesmoor word nie, dit tot 'n algemene opstand onder die Bantoe van Suid-Afrika sou kon lei. Reeds op 20 April 1906 het die kommandant van die Transvaal Volunteers 'n order uitgevaardig waarin adjudante van die verskillende korpse versoek is om so spoedig moontlik lyste van name van vrywilligers wat bereid is om in Natal te veg, aan hom te stuur.

Op 23 April 1906 het die Transvaalse regering dié vorm van hulpverlening aan Natal amptelik bespreek. Ingevolge die besluit wat daar geneem is, het die Transvaalse luitenant-goewerneur dieselfde dag die volgende telegram aan die Natalse goewerneur gestuur:

Please inform your minister's that with the High Commissioner's warmest approval, Transvaal Government offers to send to assistance of Government of Natal, whenever required, 500 Transvaal Volunteers fully armed and equipped, and offers to maintain them while in the field.

Die Natalse regering het hierdie vorm van militêre hulpverlening onmiddellik met dank aanvaar.

Op 25 April 1906 het die Transvaalse regering besluit om 'n berede regiment, die First Transvaal Mounted Rifles, met 'n getalsterkte van 500 man, op te rig. In 'n Buitengewone Staatskoerant van 26 April 1906 is die instelling van die korps afgekondig en is dit terselfdertyd vir aktiewe diens in Natal opgeroep. Die reaksie van Transvaalse kant was só oorweldigend dat in dieselfde uitgawe van die Staatskoerant 'n verdere kennisgewing verskyn het, waarin aangekondig is dat aansoeke om aansluiting by die korps nie meer oorweeg kan word nie, aangesien daar op dié stadium reeds meer as voldoende aansoeke ontvang is.

Groot sorg is aan die keuring van lede van die eenheid bestee. Daar is besluit om lede uit die verskillende bestaande berede vrywilligerkorpse in Transvaal aan te stel, sodat hulle almal aan die veldtog kon deelneem.

Die First Transvaal Mounted Rifles is soos volg saamgestel: Die A-eskadron uit lede van die Imperial Light Horse, die B-eskadron uit lede van die South African Light Horse, die C-eskadron uit lede van die Johannesburg Mounted Rifles en die Scottish Horse, terwyl die D-eskadron uit lede van die Northern, Eastern en Western Mounted Rifles bestaan het. 
Die mate van die slaggereedheid wat die Transvaal Volunteers aan die einde van die Kroonkoloniebestuurstydperk bereik het, kan afgelei word uit die spoed waarmee die saamgestelde berede eenheid gemobiliseer is.

Mobilisasie van die korps is op 26 April 1906 afgekondig, en op 27 April 1906 het die eerste kontingent van 250 man ten volle toegerus na Natal vertrek. Op 30 April 1906 was die saamgestelde eenheid se mobilisasie volledig afgehandel en het die laaste klein groepie na Natal vertrek.

Die Transvaal Volunteers se bydrae tot die gevegsmagte in Natal was nie tot die mobilisasie van die First Transvaal Mounted Rifles beperk nie. Die Natalse regering het op 10 Mei 1906 besluit om 'n ongereelde infanterieregiment met 'n sterkte van 800 man op te rig om die reserwe-milisie, wat op daardie tydstip te velde diens gedoen het, af te los. Hierna het bogemelde regering die Hoë Kommissaris versoek om toe te laat dat die helfte van dié regiment in Johannesburg gewerf word. Lord Selborne het hiertoe tozgestem, en daar is besluit dat, indien moontlik, aan elke infanterie-eenheid van die Transvaal Volunteers die geleentheid gegun moes word om een kompanie infanteriste op die been te bring.

Op 11 Mei 1906 is in Transvaal amptelik om infanterie-vrywilligers gevra. Uit die volgende bestaande eenhede is vier kompanies met 'n getalsterkte van 100 man elk saamgestel: Die Central African Railway Volunteers; die Transvaal Light Infantry en die Transvaal Cycle Corps gesamentlik; die Transvaal Scottish Volunteers en die Witwatersrand Rifles. 'n Maxim-masjiengeweer-afdeling is ook deur die Central South African Railway Volunteers verskaf, terwyl uit hierdie korps en die Volunteer Corps of Military Signallers 'n seiners-afdeling gevorm is. Uit die Transvaal Volunteer Medical Staff Corps is 'n draagbaarafdeling gevorm. Saam met die toegevoegde dienseenhede was die halwe infanterieregiment se getalsterkte 445 man.

Op 16 Mei 1906 het hierdie infanteriste, ten volle toegerus, na Natal vertrek. Die ooreenkoms tussen die twee regerings was dat die Natalse regering hulle wapens, klere en toerusting teen kosprys van die Transvaalse regering sou oorneem.

Die totale aantal Transvaalse vrywilligers wat aan die Zoeloe-opstand deelgeneem het, soos hieronder gesien kan word, was 980.

Die halwe regiment infanteriste het drie maande lank te velde diens gedoen. Hulle het aan die een groot veldslag van Momevallei (10.6.1906) deelgeneem. Hierna het hulle egter slegs in kleiner operasies opgetree.

In teëstelling hiermee het die First Transvaal Mounted Rifles, onder 1t.-kol. W. F. Barker, 'n leidende aandeel in die mees beslissendste veldslae gehad wat tydens die opstand gelewer is.

Waar die aandeel van die Transvaalse Volunteers in die operasies tydens die opstand hier geskets word, sal hoofsaaklik die rol van die First Transvaal Mounted Rifles aandag geniet. Die rol van die Natal Rangers sal, waar toepaslik, ook aangedui word. 'n Probleem is dat uit die geraadpleegte bronne nie kan vasgestel word nie of d:e Transvaalse of Natalse gedeelte van die Natal Rangers aan 'n besondere operasie deelgeneem het. 
A

B

Naam van Transvaalse eenhede wat deelgeneeem het
$\mathrm{C}$

D

\begin{tabular}{|c|c|c|c|c|}
\hline $\begin{array}{l}\text { Volg- } \\
\text { no. }\end{array}$ & $\begin{array}{c}\text { Naam van Transvaalse eenhede } \\
\text { wat deelgeneeem het }\end{array}$ & $\begin{array}{c}\text { Goedgekeurde } \\
\text { sterkte } \\
1.7 .1907\end{array}$ & $\begin{array}{c}\text { Werklike } \\
\text { sterkte } \\
1.7 .1907\end{array}$ & $\begin{array}{l}\text { Lede wat aktief } \\
\text { aan bekamping } \\
\text { van Zoeloe- } \\
\text { opstand deelge- }\end{array}$ \\
\hline
\end{tabular}

$\begin{aligned} \text { 1. } & \text { Transvaal Horse Artillery } \\ \text { 2. } & \text { Imperial Light Horse } \\ \text { 3. } & \text { South African Light Horse } \\ \text { 4. } & \text { Johannesburg Mounted Rifles } \\ \text { 5. } & \text { Scottish Horse } \\ \text { 6. } & \text { Northern Mounted Rifles } \\ \text { 7. } & \text { Western Mounted Rifles } \\ \text { 8. } & \text { Eastern Mounted Rifles } \\ \text { 9. } & \text { Central South African Railway Volunteers } \\ \text { 10. } & \text { Transvaal Light Infantry } \\ \text { 11. } & \text { Transvaal Scottish } \\ \text { 12. } & \text { Witwatersrand Rifles } \\ \text { 13. } & \text { Transvaal Cycle Corps } \\ \text { 14. } & \text { Ist Volunteer Transport Company } \\ \text { 15. } & \text { Volunteer Company of Military Signallers } \\ \text { 16. } & \text { Transvaal Volunteer Medical Staff Corps }\end{aligned}$

156
528
528
528
528
1039
1039
1039
1073
812
943
1336
446
108
108
511

138

263

318

356

392

668

243

658

800

487

628

630

328

92

31

398
3

107

109

70

80

57

15

33

126

70

106

129

26

17

10

22

Teen die einde van April 1906 was die fokuspunt van die opstand die Nkandhlawoude in Zoeloeland.*

Om die opstand by Nkandhla uit te wis, het die Natalse regering op 28 April 1906 'n sterk mag, die Zululand Field Force, saamgestel, wat onder bevel van kol. D. McKenzie, C.B., K.C.M.G., J.P., V.D., Natal Carbineers, geplaas is en soos volg saamgestel was: Die First Transvaal Mounted Rifles: 500 man; die Royston's Horse: 550 man; die Natal Field Artillery: 95 man (twee afdelings van 35, waarvan elk oor twee 15-ponder kanonne beskik het en een afdeling van 25 wat oor twee pom-poms beskik het), die Durban Light Infantry: 320 man (3 kompanies, waaronder 25 berede infanteriste), die Zululand Mounted Rifles: 150 man, die Natal Naval Corps: 106 man, die Natal Police: 200 man, die Zulu Police: 90 man, en verder ook toegevoegde mediese-, veeaartsenykundige-, seiner- en dienseenhede.

Die grootste gedeelte van die Zululand Field Force, waaronder ook die First Transvaal Mounted Rifles, het eers op Dundee saamgetrek. Op 30 April 1906 het kol. McKenzie na Dundee vertrek, en op 1 Mei 1906 het hy die bevel oor die mag aanvaar. Op 3 Mei 1906 het sy kolonne van Dundee vertrek, en op 8 Mei het dit by die Nkandhla-landdroskantoor aangekom.

* Nkandhla is die versamelnaam vir 'n groot aantal feitlik aaneengeskakelde woude in die bergagtige streek van elf myl lank en vyf myl breed in die Nkandhla-landdrosdistrik. Die berghange, valleie en bergklowe het hier besonder steil heinings en is boonop dig begroei oor ' $n$ baie onegalige grondoppervlak. Die woude self is haas ondeurdringbaar. Dat die opstandelinge hulle dus in groot getalle in hierdie natuurlike vesting gemonster het, is begryplik. 
Die gevegsterrein by Nkandhla was heeltemal vreemd en moes eers verken word. Die terreingesteldheid en veral die beskikbaarheid van voldoende woudskuiling vir die rebelle het kol. McKenzie laat besef dat hulle nie maklik tot oorgawe gedwing sou kon word nie. Voedselvoorrade in die omgewing van die groot woude soos Nkandhla, Qudeni, Kombe, Eusingahantu en Macala sou eers vernietig moes word, anders sou die opstandelinge bedags in die woude kon skuil en snags kos insamel.

Dit was van die begin af kol. McKenzie se oogmerk om so spoedig moontlik met die rebellemagte in botsing te kom en hulle in beslissende veldslae te verslaan. Ondertussen het hy hom daarop toegelê om verkenningswerk te doen, voedselvoorrade van die rebelle te vernietig en hulle krale af te brand.

Die eerste drie weke van die veldtog, tot die einde van Mei, het teleurstellend verloop. Kol. McKenzie het probeer om 'n beslissende veldslag te lewer, maar ondanks die feit dat die rebellemag in die woude steeds aangegroei het, het die geleentheid hom daartoe nie voorgedoen nie.

Die rebelle het klaarblyklik 'n defensiewe taktiek gevolg. Hulle het in klein groepe tussen die digbegroeide, haas ondeurdringbare woude heen en weer beweeg en openlike botsings met groot kolonnes vermy. Hulle enigste vorm van aanval was om telkens te probeer om kleiner troepe-afdelings te oorval.

Op 15 Mei het slegs lt.-kol. Barker se kolonne een keer met 'n impie van sowat 500 man sterk in aanraking gekom. Dit was toe hy by Dhlowana, ses myl suid van Ntingwe en omtrent drie myl van Macala af, besig was om krale af te brand, dat hy in 'n skermutseling met die impie betrokke geraak het. In hierdie skermutseling is vier rebelle gedood. Volgens Stuart het lt.-kol. Barker hier 'n besliste geleentheid om die rebelle hulle eerste swaar verliese toe te dien, laat verbygaan. Op $16 \mathrm{Mei}$ het lt.-kol. Barker 'n klein afdeling uitgestuur om die rebelle te probeer uitlok, dog dit was vergeefs.

Die Natalse regering het teen die einde van Mei 1906 besef dat die gevegsmagte in Natal en die in Zoeloeland onder een bevel geplaas moes word. Dit sou beter koördinasie tot gevolg hê.

Op 30 Mei 1906 is kol. McKenzie as opperbevelhebber van alle magte te velde aangestel. Hy was vasberade om, onder sy persoonlike leiding, die opstand by Nkandhla te onderdruk. Omdat kol. Leuchars tot op dié stadium die operasies in Natal met welslae gehanteer het, het kol. McKenzie hom versoek om daarmee voort te gaan tot tyd en wyl die Nkandhla-opstand onder beheer is. Hierna sou hy self die bevel oor alle troepe oorneem.

Teen die einde van Mei het kol. McKenzie besluit om die rebelle uit hulle skuilplekke te verdrywe. Vanaf 1 Julie het hy begin om die Nkandhla-woude met die manskappe tot sy beskikking so sistematies moontlik te deurkruis.

Op 4 Junie 1906 is sy magte wesenlik versterk toe die Natal Rangers, onder It.-kol. Dick, by sy Nomancikamp aangekom het. Tot 8 Junie het die Natal Rangers saam met die res van die Nkandhla-mag, waaronder die First Transvaal Mounted Rifles, aan 'n reeks dryftogte deelgeneem wat nie veel opgelewer het nie.

Terwyl die troepe op 9 Junie gerus het na 'n uitputtende dryftog van die vorige dag, het 'n groot drama stil-stil 'n aanvang geneem. Dit was die voorspel tot die belangrike veldslag van Momevallei, waarna die opstand in Zoeloeland feitlik verby was.

'n Paar dae voor 9 Junie het kol. McKenzie aan sy plaaslike inligtingspersoneel, bestaande uit lt. Helges en sersante Calverley en Titlestead, opdrag gegee om vas te stel waar die Zoeloehoof Sigananda hom skuilhou. Laasgenoemde was hoof van 'n groot stam in die Nkandhla-distrik wat in opstand was. Een van Sigananda se stam- 
lede wat op 8 Julie oorgegee het, was aan sers. Calverley goed bekend. Bygevolg het die inligtingspersoneel besluit om hom as spioen aan te wend. Gedurende die namiddag van 9 Junie is hy na die Mome-woud geneem. Hier is aan hom opgedra om na 'n Zoeloe, genaamd Mandisindaba, wat ook aan sers. Caverley goed bekend was, te gaan soek. Kort voor lank het die spioen met Mandisindaba en laasgenoemde se hele gesin en beeste opgedaag. Mandisindaba het aan sers. Calverley meegedeel dat hy moeg vir die opstand was en hy het om beskerming vir sy gesin en beeste gevra. Dit het sers. Calverley onderneem, maar met dié voorbehoud dat Mandisindaba onmiddellik na die Mome-woud moes gaan en presies sou vasstel waar Sigananda hom skuilhou. Aan Mandisindaba is te verstane gegee dat as hy in hierdie sending sou slaag, dit oorweeg sal word om sy deelname aan die opstand te kondoneer. Hierna is hy dadelik die woud in, waar dit hom geluk het om 'n rebel raak te loop wat toevallig ook na Sigananda op soek was. Laasgenoemde moes 'n boodskap aan Sigananda oordra dat twee leiers van die opstand, Mehlokazulu en Bambata, dieselfde aand met sowat twintig kompanies van die Qudeni-woud na die Mome-woud sou beweeg om by Sigananda se magte aan te sluit.

Terwyl Mandisindaba en sy nuwe metgesel hulle soektog gesamentlik voorgesit het, het Mandisindaba 'n Zoeloetjie met kos in die rigting van een van die bergklowe sien beweeg. Hier het een van Sigananda se vrouens die kos geneem en die bergkloof binnegegaan. Dit was duidelik dat Sigananda hom êrens in die onmiddellike omgewing bevind het.

Onder die voorwendsel dat dit al begin donker word, het Mandisindaba voorgestel dat hulle in verskillende rigtings na Sigananda moes soek. Dié een wat hom eerste sou kry, sou dan vir die ander een skreeu. Toe Mandisindaba uit die gesig van sy vroeëre metgesel was, het hy hom na sers. Calverley en sers. Titlestead gehaas om sy waardevolle inligting mee te deel. Teen halftien die aand is die inligting aan kol. McKenzie in die Nomancikamp oorgedra. Wel wetende dat die Zoeloes te bygelowig is om 'n woud in die nag binne te gaan, het kol. McKenzie van die veronderstelling uitgegaan dat die impie by die ingang van die woud sou oornag en dit eers teen dagbreek die volgende oggend sou binnegaan. Dit moes teen elke prys verhoed word. Kol. McKenzie het aangeneem dat die rebelle deur die Insuzivallei sou beweeg, aangesien dit die maklikste pad was. Die gewenste stap sou dus wees om die impie by die suidelike ingang tot die Nkandhla-woud voor te lê. Omdat kol. McKenzie se kamp ten noorde van die Nkandhla-woud geleë was, moes dié taak aan 'n kolonne suid van die woud opgedra word. Dié taak is bygevolg aan ltkol. Barker se kolonne, wat op daardie tydstip in die omgewing van Cetshwayo se graf ten suide van die Nkandhla-woud gekampeer het, opgedra. Barker se Halambukamp was sowat sewe of agt myl van die mond van die Momevallei, die ingang tot die Nkandhla-woud, geleë. Die geskrewe operasie-order wat kol. McKenzie om halfelf die aand aan lt.-kol. Barker gestuur het, is so belangrik dat dit woordeliks weergegee word.

Zululand Field Force, Camp, Nomanci Ridge, 9th June, 1906.

\section{From O.C. Troops to Colonel Barker.}

On receipt of this despatch you will please move at once with all available men (leaving sufficient for the defence of your camp) to the mouth of the Mome Valley. I have information that an impi is coming from Qudeni to enter Mome Valley between this and to-morrow morning. Please try to waylay this impi and prevent them 
from entering the Mome and at daylight block the mouth of the Mome at once. It is anticipated that they will not enter the Mome till daylight. I have reliable information as to almost the exact spot Sigananda is in, and I am moving from here to surround him. He is supposed to be just below the Mome stronghold a little lower down where we burnt his kraal. I will cut off this portion at daylight and drive down towards you so please do all you can to prevent his escape and cooperate with me generally.

At daylight please send the Zululand Police and Native levies up to Sigananda's kraal which you burnt the day we attacked the stronghold where they will join forces. You must take your gun and maxims in case you meet the impi which is reported to be of strength.

Look out for my signals.

Addressed. Colonel Barker. Cetshwayo's Grave.

Very urgent. Sent 10.30 p.m.

Om tienuur is hierdie order met drie boodskappers na lt.-kol. Barker se kamp gestuur. Kol. McKenzie het dit só belangrik geag dat hy hom persoonlik daarvan vergewis het dat al drie boodskappers op hoogte van die inhoud was. In geval van enige gebeurlikheid moes een van hulle in elk geval probeer om die inhoud oor te dra al sou dit dan ook mondelings geskied. Teen eenuur was die order veilig by lt.-kol. Barker afgelewer. Laasgenoemde se kolonne het die kamp reeds teen tweeuur verlaat. Dit het bestaan uit: Drie eskadrons van die First Transvaal Mounted Rifles (B-, C- en D-eskadrons); 90 lede van die Natal Police; een seksie van die Natal Field Artillery met twee 15-ponder kanonne; een maxim en een ,colt"-kanon; 100 lede van die Zululand Native Police en omtrent 600 man Zoeloehulptroepe.

Naby Cetshwayo se graf het inspekteur C. E. Fairlie met die Zululand Native Police en Zoeloehulptroepe die hoofkolonne verlaat om stelling te gaan inneem in 'n posisie bokant 'n groot draai in die Momerivier. Dit was sowat 200 tree onderkant die peervormige Dobo-woud. Die oogmerk was om die Momevallei vanaf die noordekant te blokkeer om te verhoed dat die rebellemag die Mome-woud kon binnegaan. Indien daar egter 'n uur na sonop, dus op die 10de, niks gebeur het nie, moes inspekteur Fairlie na Sigananda se afgebrande kraal gaan om met kol. McKenzie saam te werk.

Teen omstreeks drie-uur het die voorhoede van lt.-kol. Barker se kolonne, die Ceskadron First Transvaal Mounted Rifles, die kampeerplek van die rebelle in 'n halfmaanvormige vallei noord van die Insuzivallei en wes van die Momerivier naby die samevloeiing van die Insuzi- en Momerivier opgemerk. Hierdie kampeerplek was net suid van die ingang tot die Momevallei geleë. Volgens raming was daar omtrent 600 tot 800 rebelle.

Lt.-kol. Barker het onmiddellik sy troepe só opgestel dat die rebellekamp omsingel is. C-eskadron First Transvaal Mounted Rifles en vyftig lede van die Natal Police met 'n ,colt'-kanon van die First Transvaal Mounted Rifles het 'n bergrif wes van die halfmaan beman, . B- en D-eskadrons het met 'n maximkanon teen 'n bergrif oos van die kamp stelling ingeneem. Beide groepe moes noordwaarts uitsprei en probeer om met inspekteur Fairlie se manskappe in verbinding te kom. Die twee 15-ponder kanonne van die Natal Field Artillery is op 'n koppie teenoor die suidelike ingang van die halfmaan geplaas. Hierdie koppie was reg wes van die kamp geleë. Die kanonne was sowat 1.200 tree van die kamp af. 'n Berede reserwe van die Natal Police is in 'n posisie naby die kanonne geplaas met hulle perde in gereedheid om te verhoed dat die vyand in die Insuzivallei terugval en ontsnap. 
Vooraf is afgespreek dat die aanval teen dagbreek sou begin. Die teken hiervoor sou op bevel van lt.-kol. Barker self deur een van die 15-ponders gegee word.

Nadat die kampvure in die halfmaan uitgebrand was, was die rebellekamp as gevolg van 'n digte mis heeltemal onsigbaar. Toe die mis teen ongeveer 6.45 begin opklaar, was die rebelle al besig om voorbereidings vir die voortsetting van hulle mars te tref.

Hulle het eerste van die teenwoordigheid van die C-eskadron First Transvaal Mounted Rifles bewus geword. Die steil berghang wat hierdie eskadron moes beset, het hulle gedwing om so na as 150 tree van die rebellekamp posisie in te neem. Die rebelle het dadelik hulle tradisionele horingformasie gevorm en aangeval. Ceskadron moes dus sonder om op die aanvalsein te wag, begin skiet. Hierna het 'n hewige spervuur van alle kante gevolg. In die rebellekamp het 'n algehele wanorde geheers. Hulle het verward heen en weer geskarrel, toerusting, jasse en blikke op die grond gegooi en wanhopig skuiling probeer soek. Dié wat stroomop in die Momerivier die Nkandhla-woud probeer bereik het, is deur inspekteur Fairlie sowel as kol. McKenzie se troepe voorgekeer. Slegs enkeles was gelukkig genoeg om veilig die woud te bereik. $\mathrm{Na}$ ongeveer twintig minute is die spervuur gestaak en het die omsingelende troepe met 'n dryftog oor 'n breë terrein in die rigting van die peervormige Dobo-woud begin. Baie rebelle is in hulle skuilplekke opgespoor en gedood. Teen tienuur was die dryftog verby. Volgens lt.-kol. Barker se skatting het sy mag sowat 300 rebelle gedood.

Die res van die dag se operasies het bestaan uit 'n sistematiese dryftog deur die Dobo-woud. Volgens plan het kol. McKenzie vroeg in die oggend een deel van sy kolonne verder noord teen die oostelike en westelike hange van die Momevallei opgestel om rebelle, wat moontlik stroom-op in die Momerivier sou probeer ontvlug, voor te keer. Met 'n ander deel van sy kolonne sou hy probeer om Sigananda en sy volgelinge te verras.

Toe lt.-kol Barker se mag die geveg begin het, het kol. McKenzie dadelik met die grootste deel van sy kolonne die Momerivier vanuit die noorde geblokkeer en stroomaf met die rivier beweeg. Hierdeur het hy die vlugtende rebelle verplig om in die Dobe-woud skuiling te soek. Om te verhoed dat hulle hieruit ontsnap, is 'n ander deel van sy kolonne noord van die woud geplaas. In die deurkruising van die woud het die Natal Rangers 'n belangrike rol gespeel. Na raming is sowat 100 rebelle in die dryftog gedood. Omdat die bedding van die bergkloof in die woud nie deursoek kon word nie, het 'n aantal rebelle, wat hier verskuil was, ontsnap. 'n Paar van die belangrike rebelleleiers het in hierdie veldslag gesneuwel, onder wie o.a. Mehlokazulu en Bambata. Weens die verloop van die operasies is 'n poging om Sigananda te vang, laat vaar.

Die Mome-veldslag het die opstand in Zoeloeland prakties beëindig. Hierna het net afrondingswerk oorgebly. Dit het hoofsaaklik daaruit bestaan om rebelle in die geleentheid te stel om hulle oor te gee en dié wat onwillig was om oor te gee, te arresteer.

Teen 19 Julie het 'n nuwe opstand in die distrik Mapumulo in Natal uitgebreek. Dit het vinnig versprei. Op 25 Junie het kol. McKenzie uit Zoeloeland vertrek om aandag hieraan te gee. 'n Aantal troepe is in Zoeloeland agtergelaat om die opruimingswerk af te handel. Onder hulle was drie kompanies Natal Rangers; in totaal sowat 300 man sterk.

Die oppervlakte van die gebied waarin die nuwe opstande uitgebreek het, was ongeveer agt-en-dertig $\mathrm{km}$. suid na noord en vier-en-sestig $\mathrm{km}$. van oos na wes. Dit 
was in die vorm van 'n langwerpige vierhoek, waarvan Balcombe die noordwestelike-, Bondsdrift die noordoostelike-, Noodsberg die suidwestelike- en Stanger die suidcostelike hoek gevorm het. Die opstand het verder ook suid van Stanger na die kus se kant toe gesmeul.

In hierdie gebiede was die rebellemagte in twee groot impis verdeel, nl. in die Tugelavallei noord van Mapumulo en een in die Umvotivallei, tussen Noodsberg en Stanger. Tussen die twee valleie het 'n wapad na Stanger geloop, wat feitlik die verdelingslyn was. Die oppervlakte se gesteldheid in die Tugelavallei is redelik ru en onegalig, terwyl die suidelike gebied hoofsaaklik uit doringbosgebied bestaan. Hier kon berede troepe gemaklik en vinnig beweeg. Uit 'n militêre oogpunt beskou was die nuwe gevegsterrein baie meer begaanbaar as dié van Zoeloeland. Verder was sowel die noordelike as die suidelike gebiede van goeie spoorverbindings voorsien.

Kol. McKenzie se uitgangspunt was om die verspreiding van die opstand te verhoed deur die rebellemagte te omsingel. Hiervoor het hy 2.500 troepe by Thrings Post, in die noorde van die gebied, saamgetrek. Lt.-kol. Barker se mag van 500 man is na Esidumbini in die suidweste gestuur, terwyl lt.-kol. G. Mansel, C.M.G., met 'n kolonne aan die Zoeloelandse kant van die Tugela moes opereer om te verhoed dat die opstand weer na Zoeloeland versprei. Hierdie troepe-opstelling was reeds op 2 Julie voltooi.

Op 2 Julie 1906 was lt.-kol. Barker se kolonne, bestaande uit vier eskadrons Transvaal Mounted Rifles (400 manskappe) twee maxim- en een ,colt"-kanon (25 manskappe), twee 15-ponderkanonne van die Natal Field Artillery (25 manskappe) en die New Hanover Reserves (70 manskappe), op pad na Esidumbini. Terwyl die mag deur 'n wattelplantasie, sowat anderhalfmyl van die Groot Noodsberg af, beweeg het, is die voorhoede, t.w. B-eskadron First Transvaal Mounted Rifles, deur 'n impie van 350 man sterk aangeval. Die aanval is maklik afgeslaan, en die voorhoede en twee afdelings van A-eskadron het die vyand agtervolg. Sowat sestig rebelle is gedood. Teen ongeveer halftien het die kolonne die Insuzidrif bereik. Lt.-kol. Barker het hier 'n geskikte drinkplek vir die diere opgemerk en besluit om halt te hou. Hierop het die kolonne begin versprei op 'n gelyk stuk grond onmiddellik oorkant en regs van die drif. Om 'n verrassingsaanval van die vyand uit te skakel is 'n brandwag uitgestuur om te gaan stelling inneem op 'n langerige grasbedekte bergrif wat feitlik parallel met die rivier geloop het. Net regs van 'n smallerige nek waar die pad deur die bergrif geloop het, was 'n polisiestasie. Verder was daar drie of vier Bantoekrale bo-op die rif aan die linkerkant van die pad. Die brandwag het sowat dertig tree regs van die polisiestasie gaan stelling inneem; 'n afdeling van vier man is gestuur na 'n punt binne vyftien tree van een van die krale, waaromheen 'n dik struikagtige heining gegroei het.

Die vier man het skaars by die omheinde Bantoekraal aangekom, of 'n impie van sowat 500 man sterk het weerskante om die heining gebars en hulle aangeval. Hulle het onmiddellik op hul perde gespring en so vinnig moontlik na die hoofwag naby die polisiestasie teruggejaag terwyl die impie hulle agtervolg het. Die troepe van die hoofwag by die polisiestasie, sowel as die troepe by die drif, het dadelik op die aanstormende impie begin vuur. Net hierna het nog 'n impie van dieselfde sterkte as die eerste van skuinsregs agter die hoofwag uit 'n bos verskyn en ook begin aanval. Die twee impies het nou probeer om 'n omsingelingsbeweging uit te voer. Voordat dit voltooi is, het lt.-kol. Barker versterkings gestuur en is die aanval na 'n hewige geveg afgeslaan. Met soveel vasberadenheid het die vyand gestorm dat hulle nie eens hulle werpspiese gebruik het nie, maar slegs op korter steekspiese staatgemaak het. 
A- en B-eskadrons, sowel as twee afdelings van D-eskadron, het die vyand, wat in 'n noordelike rigting in die Isuzivallei gevlug het, agtervolg. Die twee 15-ponder kanonne is in posisie gebring by die kraal waar die eerste impie versteek was, terwyl die maxim en die „colt”-kanon naby die polisiestasie geplaas is. Tydens die eerste fase van die agtervolging is die kanonne doeltreffend gebruik. Hulle moes hulle vuur staak toe die agtervolgende troepe te na aan die vyand begin kom het. Die A-eskadron het in die agtervolging op 'n derde impie van sowat 500 man sterk, afgekom. Vyftig Zoeloes van hierdie impie het probeer aanval, maar die aanval is onmiddellik gestuit, waarop ook hierdie impie op die vlug geslaan het.

Teen elfuur is die agtervolgende troepe gelas om terug te keer, aangesien groepe rebelle aan beide kante van die polisiestasie opgemerk is. Teen halftwee was die troepe op die bergrif bymekaar, en teen kwart voor drie kon die mars na Esidumbini voortgesit word.

Die ongevalle van lt.-kol. Barker se kolonne was een gedood en twee lig gewond, terwyl die rebelle-ongevalle op 600 geskat is.

Nadat die troepe-opstelling in die Natalse onlusgebied afgehandel was, het die operasies in die gebied uit 'n paar groot konvergende bewegings bestaan. Die groots moontlike aantal troepe is in die bewegings betrek.

Die eerste van hierdie bewegings is op 3 Julie van stapel gestuur. Op 1 Julie is inligting ontvang dat 'n groot rebellemag by hoofman Messini se kraal besig was om te monster. Die kraal was net suid van die samevloeiing van die Umvoti- en Hlimbirivier geleë.

Die plan was om die rebelle teen dagbreek van 3 Julie ingesluit te hê, met 'n sirkel waarvan die middellyn nie meer as agt $\mathrm{km}$. sou wees nie. Die bymekaarkomplek sou Messini se kraal wees. Gedurende die nag van 2 Junie is die troepe-opstelling só gedoen dat vier kolonnes met dagbreek op 3 Julie vanuit die vier windrigtings en in samewerking met mekaar na die bymekaarkomplek sou beweeg.

'n Kolonne onder kol. Woolls-Sampson sou vanaf Maqumulo, een onder kol. Mackay vanaf 'n hoogte tussen Mapumulo en Thrings Post, een onder kol. Leuchars vanaf Glendale en die van 1t.-kol. Barker vanaf Isidumbeni inbeweeg. Die Natal Rangers het as deel van Mackay se kolonne aan die operasie deelgeneem.

Lt.-kol. Barker se kolonne het sy kamp teen dagbreek op die 3de verlaat. Volgens plan moes hy met die Mapumulopad na die Umvotidrif, sowat dertien $\mathrm{km}$. van sy kamp af, beweeg. Hier moes hy 'n aansluiting met kol. Woolls-Sampson se kolonne vorm. Sowat agt $\mathrm{km}$. van sy kamp af is sy kolonne deur 'n groot impie aangeval. $\mathrm{Na}$ 'n hewige geveg, waarin 100 rebelle gedood is, kon die mars voortgesit word. Vanweë hierdie vertraging het hy sy bestemming eers teen die middag bereik en kon hy gevolglik nie die beplande aansluiting verwesenlik nie. Nadat hy met kol. McKenzie beraadslaag het, het hy na sy kamp by Isidumbeni teruggekeer, waar hy sonder voorval teen halfagt die aand aangekom het.

As gevolg van 1t.-kol. Barker se vertraging was die beweging nie so geslaagd as wat verwag is nie; tog is sowat 350 rebelle gedood.

Kol. Mackay se kolonne, waarby die Natal Rangers ingesluit was, het wel met klein groepe rebelle in aanraking gekom en heelparty gedood. Die regte aantal kan nie vasgestel word nie. Kol. Mackay se kolonne het uit die linker- en regtervleuel van die Natal Carbineers, die B-battery en 'n pom-pomafdeling van die Natal Rangers en 'n berede infanterie van die Yorkshire and Lancashire-kontingent bestaan. Uit die aard van die saak is dit nie moontlik om hierdie gedeelte van die Natal Rangers wat aan die beweging deelgeneem het, se aandeel te bepaal nie. 
Nadat lt.-kol. Barker op 3 Julie na sy kamp by Isidumbeni teruggekeer het, het sy kolonne nie weer aan gesamentlike bewegings deelgeneem nie. Tussen 4 en 16 Julie was die kolonne steeds aktief in die omgewing van die kamp. Tussen 4 en 14 Julie het hulle sewentien rebelle gedood, 233 gevange geneem en oor die 1.000 stuks vee gebuit.

Op 16 Julie kon die First Transvaal Mounted Rifles die gevegsterrein verlaat. Na 'n paar dae verlof in Durban het hulle op 25 Julie van Durban na Johannesburg vertrek. Hier is die eenheid op 1 Augustus ontbind.

Op 7 Julie het kol. McKenzie berig ontvang dat Matshiveli, 'n hoof wie se lokasie in die rigting van Bond's Drift geleë was, by die rebelle aangesluit het. Volgens inligting het hy 'n groot groep rebelle in die diep bergklowe by Izinzimba, 'n sytak van die Tugela, by hom gehad. Omdat Matshiveli gedreig het om suikerplantasies in die omgewing van sy lokasie te vernietig, was vinnige militêre optrede nodig.

Kol. MacKenzie het vervolgens 'n gesamentlike omsluitingsbeweging van drie kolonnes onder kol. Mackay, kol. Woolls-Sampson en kol. Leuchars beplan. Hierdie operasie, wat op 8 Julie plaasgevind het, was uiters geslaagd en 547 rebelle is gedood. Slegs 'n baie klein gedeelte van die Natal Rangers het as deel van kol. Woolls-Sampson se kolonne daaraan deelgeneem. Dit is nie moontlik om hulle aandeel in dié verrigting te bepaal nie.

$\mathrm{Na}$ die operasie van 8 Julie was die opstand in Natal so te sê onderdruk. In die volgende groot omsingelingsbeweging, wat op 10 Julie uitgevoer is, is feitlik geen rebelle gevind nie. Dit was duidelik dat die Natalse rebelle na die beslissende veldslae van Insuzi, Umvoti en Inzinzimba heeltemal verstrooi geraak het en dat daar nie meer sprake van beplande gesamentlike optrede van hulle kant was nie.

Die Transvaalse gedeelte van die Natal Rangers was egter nog tot vroeg in Augustus behulpsaam in verband met roetine-opruimingswerk en garnisoendienste. Op 9 Augustus 1906 het 1t.-kol: J. Dick met die hoofkwartier van die Natal Rangers in Durban aangekom om vir die demobilisasie van die eenheid te reël. Op 17 Augustus 1906 kon die Transvaalse infanteriste reeds uit Durban na Johannesburg vertrek, waar hulle gedemobiliseer sou word.

Anders as die First Transvaal Mounted Rifles is die Transvaalse infanteriste nie in die geleentheid gestel om hulle in veldslae te onderskei nie. Oor hulle gedrag te velde en die waarde van die hulp wat hulle in Natal verleen het, het die bevelvoerder van die Natal Rangers die volgende in 'n skrywe aan die kommandant van die Transvaal Volunteers opgemerk:

You may welcome the half battalion back in full assurance that they have been willing hard workers both in active operations and on garrison duty; That they have never lagged behind even when calls were made on them as if they were mounted men; that they have played the game throughout, and that they have come out of the campaign with clean hands. I venture to congratulate you, Sir, on the highest satisfaction you cannot help but feel on the half battalion's record in Natal.

Volgens Stuart is vyf lede van die First Transvaal Mounted Rifles gedurende die krygsoperasies van 1906 dood.* $^{*}$

\footnotetext{
* Dit kan nie bepaal word of die twee lede wat van die Natal Rangers oorlede is, lede van die Transvaalse Vrywilligermag was nie.
} 
Gedurende 1908 het die Transvaalse regering by die Britse kroon aansoek gedoen om die toekenning van die gevegsonderskeiding Natal 1906 aan alle Transvaalse eenhede wat aan die operasie tydens die Zoeloe-opstand deelgeneem het. Hierdie aangeleentheid is na die Britse Army Council verwys. Hierdie raad het die volgende beslissing gegee: Wanneer eenhede nie buite hulle landgrense aan gevegte deelneem nie, is hulle alleen op gevegsonderskeidings geregtig as hulle hoofkwartiere en vyftig persent van die lede van die eenheid aan die operasie deelgeneem het.

Die Army Council was van mening dat, met betrekking tot die Transvaalse troepe, Natal nie as synde buitekant hulle landsgrense beskou kon word nie. Alleen die hoofkwartiere van die saamgestelde berede eenheid, die First Transvaal Mounted Rifles en dié van die Natal Rangers, waarvan Transvaalse infanteriste 'n halwe bataljon gevorm het, het aan die krygsverrigtings deelgeneem. Geeneen van die individuele Transvaalse vrywilliger-eenhede het dus, in terme van hierdie uitspraak, vir die onderhawige gevegsonderskeiding gekwalifiseer nie. 
5

\section{DIE STREWE NA INTERKOLONIALE MILITERE SAMEWERKING (1906-1909)}

Die verdere ontwikkeling van die Transvaal Volunteers sal ongetwyfeld beter begryp word indien dit teen die agtergrond van die strewe na interkoloniale militêre samewerking tussen die jare 1906 en 1909 bestudeer word.

Die gedagte aan militêre samewerking tussen die Suid-Afrikaanse kolonies was teen 1906 geensins nuut nie. Reeds in 1904 het Milner nouer militêre samewerking tussen dié kolonies in die vooruitsig gestel. Hy het gehoop om in die toekoms, wanneer 'n federasie van die vier kolonies moontlik sou wees, die verskillende koloniale polisiemagte, soos die Cape Police, die South African Constabulary en die Cape Mounted Rifles, tot een polisiemag saam te snoer. Die verskillende vrywilligermagte moes op soortgelyke wyse in een verdedigingsmag omskep word. Sy opvatting was dat reeds op 'n vroeë stadium in hierdie rigting gedink en beplan moes word.

Milner se beskouings was tipies neo-imperialisties, naamlik dat die moederland die reg moet besit om 'n gedeelte van so 'n vrywilligermag vir imperiale doeleindes buite die kolonies te gebruik. Dit was egter eers na die 1906 se Zoeloerebellie in Natal dat daar in Suid-Afrika besef is dat daadwerklike optrede ten opsigte van militêre samewerking noodsaaklik geword het.

Vroeg in Oktober 1906 het die Kaapse regering die Hoë Kommissaris, graaf Selborne, versoek om 'n konferensie ter bespreking van die ko-ordinasie van die verskillende verdedigingsmagte in Brits-Suid-Afrika te belê. Die ander koloniale regerings het hulle met hierdie versoek vereenselwig, en die konferensie het, onder voorsitterskap van die Hoë Kommissaris, op 21 Januarie 1907 in Johannesburg begin.

Die kolonies is deur die volgende persone verteenwoordig: Die Kaapkolonie deur kol. C. P. Grewe, C.B. (Koloniale Sekretaris) en kol. H. T. Lukin, C.M.G., D.S.O. (Kommandant-generaal); Natal deur dr. O'Grady Gubbins (Koloniale Sekretaris) en maj. J. H. Blew; Transvaal deur P. C. Duncan, C.M.G. (Koloniale Sekretaris) en kol. sir Aubrey Woolls-Sampson, K.C.B.; die Oranjerivierkolonie deur lord Basil Blackwood (Adjunk-Koloniale Sekretaris) en genl. Olivier; Suid-Rhodesië deur sir William Milton (Administrateur). As raadgewers van die Hoë Kommissaris het 1t.-kol. R. S. Curtis, D.S.O., opgetree (Inspekteur-Generaal South African Constabulary), lt.kol. R. Chester-Moster (Kommandant-generaal van Suid-Rhodesië en kol. C. J. Briggs (Kommandant van die Transvaal Volunteers).

Die konferensie het allereers besluit dat 'n ooreenkoms vir die gesamentlike verdediging van die Suid-Afrikaanse kolonies onverwyld tot stand moet kom. Hierdeur sou die uiteindelike federasie van die koloniale verdedigingsmagte moontlik word. Die besluite van die konferensie sou die basis van 'n konsep-ooreenkoms vorm. Na die konferensie sou dié ooreenkoms aan die vier koloniale parlemente in Suid-Afrika en aan die regering van Suid-Rhodesië vir goedkeuring voorgelê word.

Op dié konferensie is. o.m. eenstemmigheid oor die volgende belangrike sake bereik:

(i) In geval een kolonie in oorlog of onluste betrokke raak, sal hy die reg hê om hulp van ander kolonies aan te vra. 
(ii) Indien 'n kolonie, waarop 'n beroep gedoen word vir die verskaffing van troepe, dié troepe vir die verdediging sou benodig, kon die uitvoerende gesag van so 'n kolonie besluit om nie hulp te verleen nie.

(iii) Enige verskil van mening tussen twee of meer kolonies oor die toepassing of interpretasie van die bepalings van die beoogde ooreenkoms sou na die Hoë Kommissaris verwys word. Laasgenoemde sou dan, op sy beurt, menings van die ander party(e) inwin en 'n finale beslissing vel.

(iv) Dié kolonie wat troepe van ander kolonies aanvra, sou die volledige koste daaraan verbonde, vanaf die dag van mobilisasie moes dra.

(v) Kolonies wat tot die ooreenkoms toetree, moes te eniger tyd die volgende troepe vir hulpverlening op gereedheidsgrondslag hê: Die Kaapkolonie: 1.500 man; die Transvaal-kolonie: 1.000 man; die Oranjerivier-kolonie: 500 man; Natal: 500 man, en Suid-Rhodesië: 200 man. Daar moes dus altyd 'n mag van 3.100 man sterk in Brits-Suid-Afrika beskikbaar wees.

(vi) Diensvoorwaardes vir die troepe wat kolonies op gereedheidsgrondslag moes hou, moes só wees dat hulle op enige plek in Suid-Afrika vir diens beskikbaar moes wees.

(viii) Elke kolonie moes troepe vir interkoloniale diens uit sy bestaande verdedigingsmag werf. In die Oranjerivier-kolonie het egter nog nie 'n verdedigingsmag bestaan nie. In dié geval moes die hoeveelheid troepe wat voorsien moes word, wetlik verplig word om diens te verrig wanneer hulle daarvoor opgeroep word.

(viii) Kolonies moes trag om hulle interkoloniale diens-kontingente uit die groots moontlike aantal berede troepe te laat bestaan.

(ix) Die dienstydperk van troepe van koloniale kontingente wat interkoloniale aktiewe diens verrig, is voorlopig op 'n maksimum van ses maande vasgestel.

(x) Koloniale regerings moes sorg dra dat hulle interkoloniale dienskontingente te alle tye oor voldoende perde, wapens en toerusting beskik. Die nodige ondersteuningsdienste, soos artillerie-, transport-, mediese- en voorsieningskorpse, moes deur elke koloniale dienskontingent onmiddellik toegevoeg kon word.

(xi) Geen kolonie sou die reg hê om troepe van ander kolonies aan te vra alvorens hy driekwart van sy eie vrywilliger- of burgermagte vir aktiewe diens opgeroep het nie.

(xiii) Daar is aanvaar dat elke kolonie oor 'n toereikende verdedigingsmag sou beskik om plaaslike onluste van kleiner omvang die hoof te kan bied.

(xiii) Tot tyd en wyl in die Oranjerivier-kolonie 'n verdedigingsmag opgerig sou wees, kon hierdie kolonie eers hulp inroep wanneer 'n aantal van sy manskappe gelykstaande aan driekwart van die aktiewe burgermag van Natal, d.w.s. omtrent 2.500 man, opgeroep is.

(xiv) Enige koloniale kontingent wat deur 'n beparalde kolonie tot beskikking van 'n ander kolonie gestel word, sou onder bevel staan van die goewerneur van dié kolonie waarin aktiewe diens verrig word. Laasgenoemde kon op sy beurt 'n senior offisier aanstel om bevel uit te oefen.

(xv) Die konferensie het ook aanbeveel dat interkoloniale dienskontingente van elke kolonie gedurende militêre opertasies sover moontlik bymekaar gehou moes word. 
(xvi) Interkoloniale dienskontingente wat vir aktiewe diens na ander kolonies vertrek, moes met 100 skote per kanon, 500 patrone per geweer en 20.000 patrone per masjiengeweer toegerus wees. Hierdie ammunisievoorrade moes deur elke kolonie vir onmiddellike uitreiking in voorraad gehou word.

(xvii) 'n Verdere aanbeveling was dat die indiensnemingsvoorwaardes van permanent besoldigde magte in kolonies só moet wees dat enige kolonie, indien verkies, dié troepe of 'n gedeelte daarvan vir aktiewe diens op enige plek in die Britse ryk kon aanwend.

(xviii) 'n Kolonie wat tot die ooreenkoms toetree, kon hom na 'n kennisgewing van een jaar daarvan onttrek. Gedurende daardie jaar sou die bepalings van die ooreenkoms egter vir so 'n kolonie van krag bly.

(xix) 'n Besondere aanbeveling was dat konferensies van senior offisiere jaarliks gehou moes word. Hierop moes aangeleenthede soos diensvoorwaardes, salarisskale, dissipline en die toerusting van die verskillende koloniale magte, met die oog op internasionale eenvormigheid, bespreek word.

Teen die einde van Junie 1907 het die verskillende koloniale regerings op die verslag van die Johannesburgse konferensie gereageer. Die Kaapkolonie en Natal was gereed om dit, met minder belangrike wysigings, aan hulle parlemente vir goedkeuring voor te lê; om daarna dadelik met die toepassing van die besluite te begin.

Teen hierdie tyd het die Wetgewende Raad van die Suid-Rhodesiese Administrasie reeds besluit om die aanbevelings, afhangende van die reaksie van die ander belanghebbende kolonies, in die praktyk toe te pas.

Die Transvaalse ministerie het die verslag weliswaar gunstig ontvang, maar was egter nie geneë om met die praktiese toepassing van die besluite te begin alvorens verantwoordelike bestuur in die Oranjerivier-kolonie ingestel sou wees nie.

Omdat die Oranjerivier-kolonie op die vooraand van die instelling van verantwoordelike bestuur gestaan het, het dié kroonkolonie-regering gevoel dat hy nie sy opvolger met enige besluite in hierdie verband mag belas nie. Hoofsaaklik vanweë die feit dat die Oranjerivier-kolonie nog geen selfregering gehad het nie, is gedurende 1907 niks verder aan die toepassing van die aanbevelings gedoen nie.

Een van die gewone vyfjaarlikse koloniale konferensies is in April 1907 in Londen gehou. Vir die strewe na militêre samewerking tussen die Suid-Afrikaanse kolonies was die volgende militêre besprekingspunte op hierdie konferensie van besondere betekenis: Die strategiese posisie van die Britse ryk uit 'n militêre oogpunt beskou, die moontlikheid van 'n eenvormige oorlogsorganisasie dwarsdeur die ryk, eenvormige militêre toerusting en voorrade vir alle koloniale magte en die wenslikheid dat koloniale regerings alle krygsvoorrade, veral wapens en ammunisie, deur die War Office moet bestel.

Hierdie besprekingspunte het uit memorandums voortgespruit wat deur Britse militêre deskundiges voorberei is. Die inhoud van die memorandums kon soos volg saamgevat word:

Ten opsigte van die strategiese posisie van die Britse ryk is veral drie aspekte in die eerste memorandum beklemtoon, nl. dat elke selfregerende kolonie binne die ryk sover moontlik vir sy eie binnelandse verdediging verantwoordelik moet wees, dat in geval van gemeenskaplike gevaar onderlinge hulpverlening tussen dele van die ryk volgens 'n bepaalde skema as noodsaaklik beskou word en dat die Britse oppermag ter see die hoeksteen van die ryksverdediging moet vorm. In ooreenstemming hiermee het Brittanje sy eie krygsmagte ooreenkomstig die volgende breë plan georganiseer: Eerstens is daar voorsiening vir tuisfrontverdediging, ook genoem 
tweede linie-verdediging, gemaak. Verder is voorsiening gemaak vir eerste linie-verdediging, d.i. 'n mag wat vinnig en doeltreffend in enige afgeleë oorsese deel van die Britse ryk kon optree. Doeltreffende eerste linie-verdediging het op die Britse oppermag ter see gerus.

Die implikasie van hierdie memorandum was dat elke selfregerende Britse kolonie vir sy eie tuis- en tweede linie-verdediging moes sorg. Verder is verwag dat hierdie kolonies hulle verdedigingsmagte só moes organiseer dat 'n gedeelte daarvan as eerste linie-verdediging vir imperiale doeleindes beskikbaar moes wees.

In die tweede memorandum is die belangrikheid van eenvormige oorlogsorganisasie in die Britse ryk beklemtoon. Dit is byvoorbeeld wenslik dat eenvormige benamings vir ooreenstemmende oorlogtydse formasies gebruik word. Die uitgangspunt was dat die waarde van die militêre hulp wat kolonies in die toekoms gedurende oorlogstyd aan die moederland sou bied, hierdeur verhoog sou word. Gelykvormig georganiseerde koloniale kontingente sou maklik by die groot Britse leërorganisasie inpas. Betreffende eenvormigheid van militêre toerusting en voorrade vir koloniale magte is nadruk gelê op die noodsaaklikheid dat kleingewere, wat aan die koloniale magte voorsien word, dieselfde kaliber ammunisie moet gebruik as dié wat aan die Britse leër verstrek word. Hierdeur sou die probleem van verskil in ammunisie-kaliber tydens gesamentlike operasies uitgeskakel word.

In die memorandum oor die bestelling van krygsvoorrade en veral van wapens en ammunisie deur die War Office het dit ook hoofsaaklik oor eenvormigheid, en gevolglik besparing, gegaan.

Militêre eenvormigheid dwarsdeur die Britse ryk was dié spil waarom alles gedraai het tydens die behandeling van die militêre besprekingspunte op die koloniale konferensie van 1907.

Om die invloed van die Londense konferensie op die latere militêre ontwikkeling in Transvaal in die besonder en op die Britse kolonies in Suid-Afrika in die algemeen te bepaal, is dit wenslik om by een van genl. Louis Botha se toesprake aan te knoop wat hy tydens die bespreking van militêre aangeleenthede op dié konferensie gehou het.

Genl. L. Botha het, as amptelike verteenwoordiger van Transvaal, die volgende gedagte uitgespreek:

....We, in the Transvaal, are today in a difficult position. We are sitting there entirely without any means of defence, and if for instance, the British Government were to remove the troops from there, our position would be hazardous . . . . my idea is that, if as yet we cannot bring about a general federation of South Africa we should at any rate attempt to federate on this question of defence. If we succeed in doing this, 1 think it will be a very effective way of aiding the Empire....

Eerste linie-verdediging was vir genl. Botha 'n verwyderde doelwit sover dit die Britse kolonies in Suid-Afrika betref het. Hy het hierdie kolonies se bydrae tot die ryksverdediging in dié lig beskou dat hulle vir hul eie tuisverdediging moes sorg. Dit kon alleen geskied mits hulle op militêre vlak sou federeer. Federasies van die verskillende koloniale verdedigingstelsels kon weer slegs met goeie gevolg deurgevoer word indien onderlinge militêre eenvormigheid tot stand kon kom.

Die betekenis van die Londense koloniale konferensie van 1907 moet veral daarin gesien word dat daar 'n praktiese patroon vir militêre eenvormigheid dwarsdeur die 
In die Britse kolonies in Suid-Afrika het wyd uiteenlopende militêre organisasies naas mekaar bestaan. Gebrek aan eenvormigheid was die grootste faktor wat 'n federasie van hierdie verdedigingsorganisasies in die wiele gery het. Hierdie behoefte aan eenvormigheid het aanleiding tot die belangrike militêre konferensie van Oktober 1908, Durban, gegee. Op hierdie konferensie is vrugbaar op die patroon vir militêre eenvormigheid in die Britse ryk voortgeborduur.

Van Januarie tot Mei 1908 is die interkoloniale konferensie oor spoorweg- en doeanevraagstukke in Pretoria gehou. Op hierdie konferensie is die verslag van die interkoloniale militêre konferensie van Januarie 1907, Johannesburg, te berde gebring en is die volgende mosie aangeneem:

Resolved, that this Conference, whilst sympathising with the objects sought to be achieved, is of opinion that, until some common political control for South Africa is devised, the question of common defence raised in the report of the Defence Conference of January, 1907, should stand over.

Tot na nouer staatkundige vereniging sou daar dus nie op koloniale vlak verdere aandag aan interkoloniale militêre samewerking geskenk word nie. Tog is hierdie belangrike aangeleentheid nie op die agtergrond geskuiwe nie. In 1908 het die Britse militêre opperbevelhebber in Suid-Afrika, genl. lord Methuen, met die verskillende koloniale regerings in verbinding getree oor die moontlikheid van 'n militêre konferensie van die militêre leiers van die belanghebbende kolonies insake die Suid-Afrikaanse koloniale verdedigingsmagte. Hy het dit duidelik gestel dat die besluite van die voorgenome konferensie geen kolonie sal bind nie, maar dat dit slegs as rigtinggewend aan die koloniale regerings voorgelê sal word. Die koloniale regerings het almal met hierdie gedagte saamgestem, waaruit die interkoloniale konferensie op 19 Oktober 1908 in Durban voorgekom het.

Tydens hierdie konferensie het brig-genl. G. G. Aston, C.B. (lid van die Imperiale Generale Staf in Suid-Afrika), as voorsitter opgetree, terwyl die Britse kolonies in Suider-Afrika die volgende afgevaardigdes gestuur het: Kol. H. T. Lukin, C.M.G., D.S.O. (Kommandant-generaal van die Kaapse koloniale magte); kol. sir Duncan McKenzie, K.C.M.G., C.B. (Kommandant van die Natalse Milisie); kol. P. S. Beves (Inspekteur van die Transvaal Volunteers); genl. J. B. M. Hertzog (ProkureurGeneraal van die Oranjerivier-kolonie) en sir William Milton, K.C.M.G. (Administrateur van Suid-Rhodesië).

Die onmiddellike doel van die konferensie was om, sover moontlik, eenvormigheid in die organisasie, dril, opleiding, toerusting, dissipline, indiensnemingstermyne en diensvoorwaardes van die verskillende koloniale magte te probeer bewerkstellig. Dié uiteindelike doelstelling blyk duidelik uit 'n aanhaling uit die verslag oor die verrigtings van die konferensie:

Work done now, which tends to the assimilation of the South African Forces, will save a great deal of time if closer union should be brought about, and will facilitate mutual support, whatever the future government of South Africa may be.

Die aard van die konferensie se werksaamhede was bloot adviserend. Besluite kon nie op koloniale regerings afgedwing word nie. Verder het dié beginsels, wat tydens die Londense koloniale konferensie van 1907 neergelê is, as basis vir besprekings en aanbevelings gedien. 
Die belangrikste aanbevelings wat deur die konferensie gedoen is, was die volgende: Eerstens is baie waarde aan organisasie geheg. 'n Model-leërorganisasie is vir die verskillende koloniale verdedigingsmagte aanbeveel. Hiervolgens moes elke kolonie Gor 'n klein staande mag beskik om in die behoefte aan bevelvoering, opleiding, staf, artillerie en ander tegniese dienste te voorsien. Aan hierdie koloniale staande magte moes in elke kolonie 'n vrywilliger- of burgermag toegevoeg word. Dit moes in eenhede ingedeel word, en die lede daarvan moes voldoende militêre opleiding ontvang vir die uitvoering van hulle pligte. Die instelling van reserwemagte onder erkende leiers is ook aanbeveel. Hulle sou gebruik kon word om die gereëlde, georganiseerde eenhede op oorlogsterkte te bring of om as afsonderlike eenhede vir aktiewe diens aangewend te word. Lede moes verplig word om kursusse te volg en onderneem om militêre diens te verrig.

Die konferensie was verder van mening dat die oprigting van skietverenigings aangemoedig moes word.

'n Volgende belangrike saak was die opstel van verdedigingskemas. Noukeurige aandag is geskenk aan moontlike voorafberekenbare noodtoestande waarmee die verskillende koloniale magte in die toekoms te doen kon kry. Om die doeltreffendste benutting van koloniale magte tydens sodanige noodtoestande te verseker, is aanbeveel dat verdedigingskemas so spoedig moontlik deur die verskillende kolonies opgestel moes word. Omdat sekere voorafberekenbare noodtoestande noodwendig meer as een kolonie sou raak, moes skemas vir optrede in hierdie gevalle by wyse van interkoloniale militêre beraadslaging opgestel word.

In enige noodtoestand was samewerking tussen koloniale en Imperiale troepe in Suid-Afrika altyd moontlik. Derhalwe is aanbeveel dat alle verdedigingskemas wat vir koloniale magte opgestel word, aan die Britse militêre opperbevelhebber in SuidAfrika beskikbaar gestel moes word.

Eenvormige organisatoriese indelings en benamings moes in die verskillende koloniale magte bewerkstellig word. Daar is aanbeveel dat berede troepe in regimente en eskadrons, artilleriste in batterye en infanteriste in bataljons ingedeel moes word. Daar is ook eenvormige oorlogsterktes vir genoemde formasies aanbeveel. Behalwe berede eskadrons moes alle ander formasies in koloniale magte by benadering dieselfde sterkte as ooreenstemmende formasies in die Britse leër hê. Die daarstelling van groter formasies, soos brigades, is nie nodig geag nie.

In die strewe na eenvormigheid het die konferensie veel klem op opleiding gelê. 'n Belangrike aanbeveling was dat 'n militêre kollege, soortgelyk aan die van Kingston (Kanada) of West Point (V.S.A.), vir die opleiding van toekomstige offisiere in Suid-Afrika opgerig moes word.

Vir die aanstelling en bevordering van offisiere in al die milisie- of vrywilligermagte is aanbeveel dat eenvormige kwalifikasies in die verskillende koloniale magte van toepassing gemaak moes word. 'n Komitee, bestaande uit verteenwoordigers van elke kolonie en 'n generale stafoffisier verbonde aan die staf van die Britse leërhoofkwartier in Suid-Afrika, moes aangestel word om voorstelle vir eenvormigheid in hierdie verband te formuleer.

Tewens is aanbeveel dat die toevoeging van koloniale offisiere by eenhede van die Britse Staande Mag aangemoedig moes word. In gevalle waar koloniale offisiere vir gespesialiseerde dienste benodig sou word, moes hulle spesialiseringskursusse in dié afdeling van die imperiale militêre diens deurloop.

Vir die bereiking van militêre doeltreffendheid deur ander range in die verskillende koloniale magte moes opleidingskampe verpligtend gemaak word; ook moes die vereistes vir die bereiking van militêre doeltreffendheid deur ander range in die verskillende kolonies eenvormig wees. 
Om die uiteenlopendheid van skietkunsoefeninge in die onderskeie koloniale magte uit te skakel, is voorgestel dat die kommandant van die skietskool by Bloemfontein versoek moes word om standaard-skietkunsoefeninge op te stel. Dit moes dan aan die onderskeie koloniale regerings vir oorweging voorgelê word. In die strewe na eenvormigheid was eenvormige opleidingsvoorskrifte onontbeerlik.

Die konferensie het besef dat daar, vir berede korpse in die onderskeie Suid-Afrikaanse kolonies, geen geskikte opleidingsvoorskrifte in die Britse leër bestaan nie. Derhalwe is voorgestel dat die handboek wat deur die Cape Mounted Rifles vir opleiding gebruik is, in gewysigde vorm vir alle berede korpse in die ander kolonies voorgeskryf moes word. Vir alle ander vertakkings in die koloniale magte het die konferensie sterk aanbeveel dat opleidingsvoorskrifte, wat in die Britse leër gebruik word, ook deur hulle aangewend moes word. Taktiese opleiding moes byvoorbeeld gebaseer wees op Britse opleidingsvoorskrifte soos vervat in Combined Training. Vir opleiding in organisasie en aanverwante aangeleenthede moes die Field Service Pocket Book-reeks gebruik word. Afgesien van die opleidingsvoorskrifte vir berede korpse moes alle dril- en opleidingsvoorskrifte dus van die $W a r$ Office ontvang word.

Die konferensie het verder gevoel dat opleidingsgeriewe vir eenhede van die verskillende koloniale magte verbeter sou word indien hulle hul opleidingskampe en maneuvers in samewerking met die Britse Imperiale troepe in Suid-Afrika sou reël.

Groot waarde is aan aanmoediging van die kadetbeweging geheg. Die afgevaardigdes was eenparig van oordeel dat dié beweging in staatsondersteunde skole verpligtend gemaak behoort te word. Waar kadetkorpse vrywillig in ander skole opgerig word, moes aan hulle dieselfde fasiliteite as aan dié in staatsondersteunde skole gebied word. Hierdie fasiliteite moes ook na senior kadette, dus na seuns tussen veertien en agtien jaar wat reeds skool verlaat het, uitgebrei word. Om eenvormigheid in kadetopleiding te verseker, is anbeveel dat tot die ouderdom van veertien jaar alleen liggaamlike opleiding aan kadette verskaf moes word. Onderrig in die skietkuns moes in die reël eers op hierdie ouderdom begin. Seuns bo agtien jaar moes nie toegelaat word om by kadetkorpse aan te sluit nie. Jongmanne van hierdie ouderdom kon tewens by georganiseerde milisie- en vrywilligereenhede aansluit.

Senior kadetkorpse moes ò met skoolkadetkorpse of by milisie- of vrywilligerkorpse geaffilieer word. Die konferensie het gemeen dat, indien hierdie voorstel nie aanvaarbaar sou wees nie, dit beter sou wees om nie senior kadetkorpse te organiseer nie.

Op die Johannesburgse konferensie van Januarie 1907 is standaarduniforms en persoonlike uitrusting vir interkoloniale dienskontingente van koloniale magte voorgeskrywe wanneer hulle op aktiewe diens sou gaan. Die kolonies het hulle dienskontingente daarna volgens hierdie voorskrifte van kleding en persoonlike uitrusting voorsien. Die Durbanse konferensie het bygevolg slegs enkele praktiese wysigings hierop voorgestel.

Dat die Durbanse konferensie die koloniale regerings se aandag op die internasionale bepalings vir militêre kleredrag gevestig het, is wetenswaardig. Hiervolgens moes die magte van koloniale regerings, wanneer hulle in botsing met die magte van beskaafde nasies sou kom, onderskeidende uniforms dra. In geval van oorlog teen Bantoes is voorgestel dat manskappe van sommige eenhede waarvoor uniforms nie beskikbaar was nie, 'n spesiaal ontwerpte hoed en onderskeidingsteken, soos 'n wapen op een arm, moes dra.

Ook is aandag aan die beskikbare verdedigingsmagte vir aktiewe diens, veral aan die bestaande polisiemagte, gewy. Daar is aanbeveel dat sommige polisiemagte of 
gedeeltes daarvan tydens militêre operasies onder leërbevelvoerders gebring moes word. Indien die koloniale regerings hiertoe sou oorgaan, moes vooraf aandag aan rangverskille tussen die militêre en polisiemagte in die verskillende kolonies geskenk word.

Die algemene aanbeveling was dat polisie-offisiere as juniors van hul gelykwaardige range in die Staande Mag beskou moet word. Vergeleke by milisie- of vrywilligermagte sou rangsenioriteit van polisie-offisiere volgens datum van verkryging van kommissie bereken word.

Militêre- en polisierange is volgens onderstaande vergelykende basis in ooreenstemming met mekaar gebring:

\section{Polisierange}

Kommissaris

Distriksinspekteur

(Assistent-Kommissaris)

Inspekteur

Tweede Inspekteur

\section{Militêre range}

Luitenant-kolonel.

Majoor.

Kaptein.

Luitenant.

Offisiere wat op reserwe geplaas is, moes voor mobilisasie op hoogte gehou word van die hoedanigheid waarin hulle tydens mobilisasie diens sal verrig. Indien geskikte reserwe-offisiere ontbreek, is aanbeveel dat lyste van geskikte siviele persone vir dié doel bygehou word. Ook hulle moes voor mobilisasie op hoogte gehou word van wat gedurende mobilisasie van hulle verwag word.

Daar is verder gevoel dat verdedigingskonferensies, soos die Johannesburgse konferensie van Januarie 1907, 'n jaarlikse instelling moes word. Die plek en datum daarvan sou jaarliks deur die brigadier-generaal, Generale Staf, bepaal word.

Ook is aanbevelings in verband met ondersteuningsdienste gedoen. Dit was meestal van tegniese aard en het gehandel oor die daarstelling van eenvormige genie-, telegrafie-, sein-, mediese en veeartsenykundige eenhede in die verskillende koloniale magte.

Die gees waarin die Durbanse konferensie voorgaande aanbevelings gedoen het, blyk uit die volgende aanhaling uit die verslag:

Finally, the result of their deliberations has been to make the Committee realise that much can be done at the present time to assimilate the conditions of organization, training, and discipline, in the various South African forces. Though admitting that there must be some elasticity in the combined system adopted, the Committee is struck with the importance of the several Defence Departments commencing at once to work together, and of their meeting each other in every possible way. Unless this policy is adopted, the Committee anticipates very serious delay in assimilation, whatever form of Central government may be established for South Africa, and however soon closer union may be brought about. 
Die betekenis van die Durbanse konferensie kan moeilik oorskat word. Bykans elke verandering wat na dié stadium daarvan in die Transvaal Volunteers voorgekom het, kan na die aanbevelings van die konferensie teruggevoer word.

$\mathrm{Na}$ hierdie konferensie was die ontwikkeling van die verskillende verdedigingsmagte in Brits-Suid-Afrika grootliks deur die aanbevelings van die konferensie, d.w.s. eenvormigheid op verskillende vlakke, beïnvloed. Tereg kan beweer word dat die totstandkoming van die latere Unieverdedigingsmag aanmerklik deur die werksaamhede van hierdie konferensie vergemaklik is.

In Mei 190! is die samesprekings oor verdediging deur genl. lord Methuen, brig.genl. G. G. Aston, kol. sir Duncan McKenzie en kol. P. S. Beves in Pretoria voortgesit. Hierdie samesprekings was hoofsaaklik op die militêre behoeftes van SuidAfrika na unifikasie en enkele organisatoriese aspekte rakende die daarstelling van 'n Unieverdedigingsmag gerig. Dié konferensieverrigtinge het dus nie die ontwikkelingsgang van die koloniale verdedigingsmagte tot Uniewording en daarna tot die aanname van die Unieverdedigingswet, wet no. 13 van 1912, beïnvloed nie. Bygevolg is 'n weergawe van die aanbevelings van dié konferensie, gesien die onderwerp onder beskouing, nie ter sake nie.

Vroeg in 1909 is die moontlike gevare, verbonde aan die opkomende Duitse seemag, dwarsdeur die Britse ryk sterk aangevoel. Op grond hiervan is, later in daardie jaar, 'n konferensie in Londen gehou. Dit was nie 'n Imperiale konferensie in die ware sin van die woord nie, maar die besprekings is tot verdedigingsaangeleenthede, in die besonder tot die formulering van 'n ryksverdedigingsbeleid, beperk. Daar is o.nı. ooreengekom dat al die dele van die Britse ryk bereid moes wees om bydraes tot die algemene ryksverdediging te lewer.

Die koloniale verteenwoordigers van Brits-Suid-Afrika op hierdie konferensie was: Genl. J. C. Smuts (Transvaalse Koloniale Sekretaris), John X. Merriman (Kaapse Eerste Minister), kol. E. M. Greene (Natalse Minister van Spoorweë en Hawens), A. Fischer (Vrystaatse Eerste Minister) en genl. J. B. M. Hertzog (Vrystaatse Prokureur-Generaal). Hulle het gevoel dat die Suid-Afrikaanse kolonies op die vooraand van staatkundige vereniging was. Derhalwe was hulle nie bereid om op dié tydstip verantwoordelikheid te aanvaar of om 'n daadwerklike aandeel in die verrigtinge van die konferensie te neem nie. Net soos in die geval van die Pretoriase konferensie van 1909 kon die besprekings wat uit hierdie konferensie voortgespruit het, eers na die totstandkoming van die Unieverdedigingsmag die militêre ontwikkelingsgang in Suid-Afrika beïnvloed.

By wyse van afsluiting van hierdie hoofstuk kan daarop gewys word dat die strewe na interkoloniale militêre samewerking in Suid-Afrika nie as 'n geïsoleerde verskynsel gesien moet word nie. Dit hang ten nouste saam met die drang na staatkundige eenheid gedurende dieselfde tydperk. Militêre eenheid was trouens een van die belangrikste faktore wat unifikasie in Suid-Afrika verwesenlik het.

In die Selborne-memorandum is verklaar dat die gesamentlike slaankrag van die onderskeie Suid-Afrikaanse kolonies se gevegsmagte toereikend was om enige binnelandse opstand die hoof te bied. Dit was egter te betwyfel of kleiner kolonies, soos Natal en die Oranjerivier-kolonie (hierdie kolonie het oor geen georganiseerde verdedigingsmag beskik nie), ernstige onluste in hulle gebiede sonder militêre hulp van buite sou kon onderdruk.

In geval van algemene Bantoe-onluste sou onderlinge militêre samewerking noodsaaklik wees, en dit sou op 'n geallieerde grondslag moes berus. Die grootse gebreke van geallieerde magte is gewoonlik 'n gebrek aan doeltreffende ko-ördinasie 
en die feit dat sodanige magte nie altyd vinnig genoeg op verskillende plekke gelyktydig saamgetrek kon word nie. In alle algemene noodtoestande waar blitssnelle optrede noodsaaklik is, het Suid-Afrika een gevegsmag onder een staatkundige gesag nodig gehad. Dit sou tot gevolg hê dat troepe sonder tydverlies op enige plek of op verskeie plekke gelyktydig, saamgetrek sou kon word. Verder sou alle militêre operasies vanaf een hoofkwartier en deur een opperbevel geko-ördineer kon word. So 'n mag sou bes moontlik kleiner wees as die gesamentlike gevegsmagte van die onderskeie kolonies. Benewens doeltreffender operasionele optrede sou dit ook goedkoper wees. 
6

\section{ORGANISASIE EN ONTWIKKELING (1907-1912)}

Met die instelling van verantwoordelike bestuur in Transvaal in Desember 1906, het die opperbevel van die Transvaal Volunteers van die vroeëre Luitenant-Goewerneur na die Koloniale Sekretaris oorgegaan.

Tot 1 Julie 1908 was die bevelvoerende offisier van die Transvaal Volunteers aan sowel die Transvaalse Koloniale Sekretaris as die Britse opperbevelhebber in SuidAfrika verantwoordelik vir die militêre beheer en administrasie daarvan. Na hierdie datum is die bevelhebber slegs aan die Koloniale Sekretaris verantwoordelik gestel.

Ook is die benaming van die bevelvoerende offisier vanaf 1 Julie 1908 van Commandant of the Transvaal Volunteers na Inspector of the Transvaal Volunteers verander. Die rede hiervoor was om hom van die roetine-administrasie los te maak, sodat hy meer aandag aan beleidsaangeleenthede, toesig en inspeksie kon wy.

Vir die behartiging van die roetine-administrasie is op die hoofkwartier voorsiening vir die pos van Staff Officer i/c Administration gemaak.

Op aanbeveling van die destydse Kommandant van die Transvaal Volunteers, kol. C. J. Briggs, het een van die verreikendste reorganisasies vanaf 1 Julie 1907 in werking getree. Die verandering wat hierdeur teweeggebring is, kan slegs ten volle verstaan word as die organisatoriese reëlings wat hieraan voorafgegaan het, toegelig word. Gedurende Junie 1907 het die volgende korpse hulle werwing uitsluitend aan die Witwatersrand gedoen: Die Transvaal Horse Artillery, die Imperial Light Horse, die South African Light Horse, die Johannesburg Mounted Rifles, die Scottish Horse, die Transvaal Light Infantry, die Transvaal Scottish, die Witwatersrand Rifles, die Transvaal Cycle Corps, die Volunteer Company of Military Signallers en die 1st Volunteers Transport Corps.

Verder het die Central South African Railway Volunteers en die Transvaal Volunteer Medical Staff Corps hulle werwing gedeeltelik aan die Witwatersrand gedoen, terwyl die Northern Rifles, die Western Rifles en die Eastern Rifles hulle lede in bepaalde, afgebakende, distrikte buite die Witwatersrandse gebied gewerf het.

Die totale goedgekeurde sterkte van die Transvaal Volunteers was gedurende Junie 190711.457 terwyl die werklike sterkte 6.619 man was. Die beswaar teen hierdie opset was dat daar by die totstandkoming van die Transvaal Volunteers, vanweë sentimentele oorwegings, te veel korpse ingestel is. Bygevolg was daar noodwendig oorvleuelings ten opsigte van funksies en werwingsgebiede, wat hoë administrasiekoste en swak dissipline in die hand gewerk het. Dit was veral die geval by die vyf berede korpse wat aan die Witwatersrand saamgetrek was. In Germiston byvoorbeeld het die inwonertal gedurende 1907 hoogstens die instandhouding van twee berede eskadrons geregverdig. Elkeen van die vyf berede korpse het egter geirag om op Germiston 'n eskadron in stand te hou. Gevolglik kon geeneen van hierdie eskadrons, op watter tydstip ookal, op volle sterkte kom nie. In die praktyk het dit dikwels gebeur dat, wanneer dissiplinêre stappe teen 'n lid van een korps ingestel word, hy sonder meer sy bedanking by sy korps ingedien het en maklik by 'n eskadron van een van die ander korpse in dieselfde dorp aangesluit het.

Die totale goedgekeurde sterkte van die Transvaal Volunteers van 11.457 man was, uit 'n ekonomiese standpunt beskou, nie te regverdig nie. 'n Mag van 5.000 man 
is vir die binnelandse beveiliging van Transvaal voldoende geag. Om dit reg te stel het die kommandant dit noodsaaklik geag om die berede korpse aan die Witwatersrand van vyf na twee te verminder en aan elkeen van dié korpse 'n bepaalde werwingsgebied toe te wys. Die groot probleem was op watter wyse dit gedoen moes word sonder om afguns of dislojaliteit by lede van die ander korpse wat ontbind sou moes word, te laat ontstaan. Die enigste oplossing was om al die bestaande berede korpse aan die Witwatersrand te ontbind en in die plek daarvan slegs twee nuwes in te stel. Die voorgestelde benamings van hierdie korpse was: The East Rand Mounted Rifles en The West Rand Mounted Rifles. Die kommandant van van die Transvaal Volunteers het gehoop dat, wanneer die twee voorgestelde nuwe korpse opgerig sou word, daar aansoeke ontvang sou word om van die ou korpsbenamings weer in te voer. Op dié wyse kon, ten spyte van radikale verandering, 'n deel van die militêre tradisie behoue bly.

Ook die sterktes van die onberede korpse sou verminder moes word. Hier was die probleem weer eens watter korps of korpse ontbind moes word. Die keuse het hier nie op 'n junior korps geval nie maar op die Transvaal Light Infantry omdat hierdie korps sy werwing slegs in die Johannesburgse stadsgebied gedoen het. Johannesburg was die aangewese plek om die infanterie te verminder, want in tye van gevaar sou die Witwatersrand Rifles, met afdelings wat oor die hele Witwatersrandgebied versprei was, heeltemal in staat wees om die myne te beskerm.

Met betrekking tot die ander onberede korpse het die kommandant die volgende aanbeveel: Die Transvaal Scottish, met hoofkwartier in Johannesburg en afdelings in Roodepoort, Krugersdorp en Germiston, moes in sterkte verminder word. Waar, soos hierbo aangetoon, die Scottish Horse ontbind sou word, is dit nie as wenslik beskou om die enigste ander Skotse regiment in Transvaal ook te ontbind nie.

Die sterkte van die Transvaal Cycle Corps sou eweneens verminder word. Die bruikbaarheid van dié korps in geval van mobilisasie het ontbinding daarvan nie wenslik gemaak nie. Ook die Transvaal Volunteer Medical Staff Corps se sterkte moes verminder word.

Ontbinding van die First Volunteer Transport Corps is aanbeveel op grond van die feit dat vervoer in 'n land soos Suid-Afrika tydens mobilisasie in enige vorm maklik bekombaar sou wees.

Hierdie aanbevelings is verwesenlik in die organisatoriese veranderings wat van 1 Julie 1907 af teweeggebring is.

Die volgende korpse of dele van korpse is ontbind: Die Imperial Light Horse, die South African Light Horse, die Johannesburg Mounted Rifles, die Scottish Horse, die Transvaal Light Infantry, die 1st Volunteer Transport Corps en die fietsryersen infanteriekompanies van die Northern, Eastern en Western Rifles.

Daarteenoor is die East Rand Mounted Rifles, die West Rand Mounted Rifles en die Telegraph Section as nuwe korpse ingestel.

Die sterkte van die aktiewe vrywilligers is op 5.000 vasgestel en moes soos volg versprei wees: Die Transvaal Horse Artillery: 160 man, die Northern Mounted Rifles: 450 man, die Western Mounted Rifles: 300 man, die Eastern Mounted Rifles: 600 man, die East Rand Mounted Rifles: 500 man, die West Rand Mounted Rifles: 500 man, die Central South African Railway Corps: 600 man, die Transvaal Scottish: 500 man, die Witwatersrand Rifles: 600 man, die Transvaal Cycle Corps: 320 man, die Transvaal Signalling Company en die Transvaal Field Telegraph Section: gesamentlik 100 man, en die Transvaal Medical Corps: 300 man. 'n Verdere sewentig manskappe kon na goeddunke geplaas word. 
Van 1 Julie 1907 af het die volgende naamsveranderinge in werking getree: Die Central South African Railway Volunteer Corps word die Central South African Railway Corps, die Volunteer Company of Military Signallers word die Transvaal Signalling Company, en die Transvaal Volunteer Medical Staff Corps word die Transvaal Medical Corps. Gedurende September 1907 is die naam van die West Rand Mounted Rifles na dié van Imperial Light Horse verander. Dit het terugwerkend van 1 Julie 1907 af van krag geword. Hierdeur is die senioriteit van die korps weer van 12 Desember 1902 af bereken. Gedurende November van dieselfde jaar is die benamings van die East Rand Mounted Rifles en die Imperial Light Horse onderskeidelik na Imperial Light Horse (Left Wing) en Imperial Light Horse (Right Wing) verander. Ook hierdie veranderings het terugwerkend van 1 Julie 1907 af van krag geword. Beide korpse se senioriteit is dus na 12 Desember 1902 teruggedateer. Die enigste verdere verandering gedurende 1907 het ook in November plaasgevind, toe die goedgekeurde sterkte van die Transvaal Scottish en die Witwatersrand Rifles onderskeidelik van 500 man na 400 man en 600 man na 700 man verander is. Hierdie veranderings was van 1 Julie 1907 af terugwerkend van krag.

Vroeg in 1908 is die sterkte van die volgende berede vrywilligerkorpse verander: Dié van die Imperial Light Horse (Left Wing) en die Imperial Light Horse (Right Wing) is in albei gevalle na 450 man verminder, terwyl die van die Western Mounted Rifles na 400 man vermeerder is.

$\mathrm{Na}$ hierdie reorganisasie van 1 Julie 1907 het 'n volgende groot verandering van 1 Julie 1908 af in werking getree. Hierdeur het slegs drie berede korpse bly voortbestaan, en die goedgekeurde getalsterkte van die Transvaal Volunteers is van 5.000 na 3.575 verminder. Hierdie reorganisasie was eweneens op besparing en konsolidasie gerig. Die veranderings wat hierdeur van krag geword het, was die volgende: Die linker- en regtervleuel van die Imperial Light Horse is tot een korps saamgevoeg onder die naam Imperial Light Horse, die naam van die Eastern Mounted Rifles is na die van Southern Mounted Rifles verander, die Western Mounted Rifles is ontbind en lede daarvan is in die Northern en Southern Mounted Rifles opgeneem, die bevelvoerende offisiere van korpse is toegelaat om die goedgekeurde getalsterkte met $10 \%$ te oorskry ten einde vir normale getalsverminderinge voorsiening te maak. Afhangende van hulle inskakeling by ander korpse of oorplasing na die reserwe of bedanking sou botallige offisiere voorlopig by hulle korpse aanbly. Botallige onderoffisiere en manskappe is eervol ontslaan.

Gedurende Augustus 1908 is die naam van die Central South African Railway Corps na die van Central South African Railway Engineer Corps verander. Terselfdertyd is die Transvaal Signalling Company en die Transvaal Field Telegraph Section tot een kompanie, onder die naam Transvaal Signalling and Field Telegraph Company, saamgevoeg.

Die Durbanse militêre konferensie van Oktober 1908, waartydens op interkoloniale vlak samesprekings gevoer is en aanbevelings gedoen is oor gelykvormigheid in die verskillende koloniale verdedigingsmagte, het 'n besliste uitwerking op die organisatoriese samestelling van die Transvaal Volunteers gehad en die reorganisasies wat met ingang van 1 Julie 1909 van krag geword het, was bedoel om die organisasie van die Transvaal Volunteers in ooreenstemming met die aanbevelings van hierdie konferensie te bring.

Die Transvaal Volunteers het vanaf vermelde datum die volgende veranderinge ondergaan: Die Transvaal Signalling and Field Telegraph Corps, waarvan die Transvaal Signalling and Field Telegraph-kompanie 'n deel sou vorm, die Transvaal Intelligence Corps, die Transvaal Supply Corps en die Transvaal Veterinary Corps is 
as nuwe korpse ingestel. Voorsiening is gemaak vir reserwes vir elkeen van die bestaande en nuutingestelde korpse sowel as vir 'n algemene reserwe, terwyl die naam van die Transvaal Cycle Corps na die van Transvaal Cycle and Motor Corps verander is.

'n Verdere uitvloeisel van die Durbanse konferensie was dat die hoofde van die verskillende koloniale militêre magte daadwerklik oorgegaan het tot die voorbereiding van verdedigingskemas wat in geval van moontlike toekomstige voorafberekenbare noodsituasies gebruik kon word. Die Britse militêre opperbevelhebber in Suid-Afrika het die Inspekteur van die Transvaal Volunteers versoek om die volgende twee skemas op te stel: Een vir binnelandse beveiliging, in die besonder in geval van algemene Bantoe-onluste, en een vir 'n inval van buite, in die besonder in geval van oorlog teen Duitsland, wat die posisie ten opsigte van Duits-Suidwes-Afrika behels het.*

Tot met die ontbinding van die Transvaal Volunteers is hierdie skemas nie in werking gestel nie. Tog is die skemas insiggewend, omdat aan die hand hiervan 'n beeld verkry kan word van die wyse waarop beoog is om die T.V. in 'n noodtoestand operasioneel aan te wend. Dit geld ook ten opsigte van die mate waarin die Transvaal Volunteers afhanklik was van samewerking met die imperiale troepe in Transvaal.

In sy inleiding tot die eerste skema, getiteld Simultaneous Trouble with the Natives in all the self governing colonies, merk die Inspekteur, kol. Beves, o.m. op dat dit onmoontlik is om vooruit te bepaal waar die grootste gevaar in geval van algemene onluste sal voorkom. Sy uitgangspunt was dat daar geen vasomlynde planne voorgelê kon word nie maar dat die skema slegs as 'n voorbeeld beskou moes word. Dit moes dus na gelang van wisselende omstandighede vryelik gewysig kon word.

Kol. Beves het die volgende gevaarsentrums in Transvaal voorsien: Die Witwatersrand, Wes-Transvaal en die streke noord en oos van Pietersburg.

Daar is van die veronderstelling uitgegaan dat die regering in geval van 'n noodtoestand alle bestaande eenhede onmiddellik sou toelaat om met werwing te begin om so spoedig moontlik op oorlogsterkte te kom. Verder is veronderstel dat sodanige werwing kon voortgaan totdat ' $\mathrm{n}$ tweede infanteriebataljon en 'n tweede berede regiment of korps gevorm kon word. Die mikpunt moes wees om uiteindelik 10.000 man in die veld te stoot.

Aan die Witwatersrand het die inspekteur gedurende die eerste paar dae van veronderstelde Bantoe-onluste ernstige probleme verwag, maar daarna sou die Bantoes volgens sy mening òf uit die gebied wegtrek òf onder beheer wees.

Ten tye van die opstelling van die skema het daar reeds 'n skema bestaan waarvolgens ammunisie onmiddellik aan alle afdelings van die Witwatersrand Rifles voorsien kon word. Hierdie regiment, met sy 100 fietsryers, moes aan die Witwatersrand bly tot tyd en wyl die polisie voldoende militêre versterkings ontvang het om die toestand daar te beheer. Ondertussen moes die Witwatersrand Rifles voortgaan om sy goedgekeurde getalsterkte van 500 na 800 man aan te vul. Na berekening sou dit binne drie dae kon geskied. Gedurende hierdie tydperk sou die polisie voldoende spesiale konstabels kon werf om beheer oor die Witwatersrandgebied oor te neem. Die Witwatersrand Rifles sou dan vry wees om elders diens te verrig. 
Om opstand in ander dele van Transvaal die hoof te bied, sou die vrywilligers in twee mobiele kolonnes georganiseer word. As moontlike konsentrasiepunte vir hierdie kolonnes is Krugersdorp en Pietersburg genoem. Daar kan egter eers finaal oor konsentrasiepunte beslis word wanneer bepaal kon word waar die onluste op hulle gevaarlikste is.

Die samestelling en sterkte van die twee mobiele kolonnes en die berekende tyd waarin moontlik te Krugersdorp of Pietersburg saamgetrek kon word, is soos volg bereken:

Nr. 1 - Mobiele kolonnes.

Saamtrekpunt: Krugersdorp of omgewing.

\begin{tabular}{cccccccc}
\hline & \multicolumn{9}{c}{ SAAMGETREK TE } & OP- \\
VOLG- & KORPS & \multicolumn{4}{c}{ KRUGERSDORP } & \\
NR. & 1 & 2 & 4 & 7 & 14 & MERKINGS. \\
& & dag & dae & dae & dae & dae & \\
\hline
\end{tabular}

1. Die Transvaal Horse

Artillery.

(Een battery van vier 13-ponder kanonne).

2. Die Imperial Light Horse.

$\begin{array}{rrrrr}40 & 50 & 60 & 70 & 90 \\ 250 & 350 & 450 & 550 & 700\end{array}$

*Die Imperial Light Horse moes in twee regimente verdeel word sodra 'n sterkte van 550 bereik is.

3. Die 1st Southern

Mounted Rifles.

4. Die Transvaal

Scottish.

5. Die Transvaal Cycle Corps.

$\begin{array}{llll}250 & 350 & 450 & 650 \\ 150 & 300 & 450 & 650^{*}\end{array}$

*Dalk as infanterie aan te wend.

6. Die Sig. and Field

Telegraph Company.

7. Die Central South

African Railway Engineer Corps.

(Genie).

50

$\begin{array}{lll}75 & 75 & 100\end{array}$

8. 'n Afdeling van die Cavalry Field Ambulance.

$\begin{array}{lllll}40 & 50 & 64 & 64 & 64\end{array}$

9. Die mobiele afdeling van die Veterinary Department. 
Nr. 2 - Mobiele kolonnes.

\begin{tabular}{lccccccc}
\hline & \multicolumn{7}{c}{ SAAMGETREK TE } \\
VOLG- & KORPS & & PIETERSBURG & OP- \\
NR. & 1 & 2 & 4 & 7 & 14 & MERKINGS. \\
& & dag & dae & dae & dae & dae & \\
\hline
\end{tabular}

Saamtrekpunt: Pietersburg of omgewing.

1. Die Transvaal Horse

Artillery.

(Een battery van vier

15-ponder kanonne).

2. Die Northern

$\begin{array}{lllll}40 & 50 & 60 & 70 & 90\end{array}$

$\begin{array}{llllll}\text { Mounted Rifles. } & 250 & 350 & 450 & 550^{*} & 700^{*}\end{array}$

*Die Northern

Rifles moes in twee regimente verdeel word as 'n sterkte van 550 bereik is.

3. Die Southern

Mounted Rifles.

$100 \quad 200 \quad 400$

4. Die Central South

African Railway En-

gineer Corps.

$\begin{array}{llll}50 & 75 & 75 & 100\end{array}$

(Genie).

5. Die Central South

African Railway Engineer Corps.

(Infanterie).

6. Die Witwatersrand

$200 \quad 300 \quad 400 \quad 500 \quad 700$

Rifles.

7. Die Sig. and Field

Telegraph Company.

8. 'n Afdeling Cavalry

Field Ambulance.

9. 'n Mobiele afdeling

Veterinary Depart-

ment.

$\begin{array}{rrrrr} & & 800 & 800 & 800 \\ 15 & 20 & 25 & 25 & 25 \\ 40 & 50 & 64 & 64 & 64 \\ & 6 & 6 & 6 & 6\end{array}$

Die Transvaal Cycle Corps en die Central South African Railway Engineer Corps (Genie) is by sowel nr. 1 as nr. 2-mobiele kolonnes ingedeel. Hierdie korpse sou òf tydelik òf vir so lank as wat die onluste voortduur, ter beskerming van spoorverbindings aangewend word. Die Transvaal Cycle Corps sou die westelike en suidelike en die Central South African Railway Engineer Corps die noordelike en oostelike spoorwegnetwerk beskerm. Een van hierdie korpse of albei kon by 'n derde of vierde mobiele kolonne gevoeg word indien daar só georganiseer sou word.

Alhoewel een berede regiment van die Southern Mounted Rifles tot elkeen van die kolonnes toegevoeg is, is beoog dat albei hierdie regimente by enige ander mobiele kolonne wat gevorm kon word, toegevoeg kon word. Die Southern Mounted Rifles kon ook ter bewaking van die Swazilandse grens aangewend word. Daar is egter 
van die veronderstelling uitgegaan dat Imperiale troepe die protektorate sou bewaak. Die Imperial Light Horse en Northern Mounted Rifles sou toegelaat moes word om só manskappe te werf dat elkeen twee regimente kon vorm.

Die pantsertreine, beman deur lede van die Central South African Railway Engineer Corps en ander troepe wat vir die doel aangewys sou word, sou vir die beskerming van die spoorweë aangewend word. Elkeen van hierdie treine sou met 'n 12-ponder snelvuurkanon en twee maxims bewapen wees.

Een afdeling van die 15-ponder artilleriebattery sou by die basis gehou word om tydens die onluste opleiding aan artillerie-rekrute te verskaf. Die afdeling kon egter ook later vir diens te velde aangewend word.

In geval van mobilisasie sou daar waarskynlik nie voldoende ammunisie vir 13ponder en 15-ponder kanonne beskikbaar wees nie. Die Imperiale Krygsbehoeftedepot sou versoek moes word om die nodige ammunisie beskikbaar te stel.

In die tweede skema moes rekening gehou word met aggressie vanuit Duits SuidwesAfrika. Hier is van die veronderstelling uitgegaan dat die Transvaalse grense nie deur die vyand bedreig sou word nie. Die Transvaalse eenheid sou dus saam met eenhede van die Kaapkolonie, Natal en Rhodesië as 'n aanvalsmag gebruik word. Kimberley is as bymekaarkomplek vir so 'n aanvalsmag gekies. Hiervandaan kon die Transvaal Volunteers na die kus gestuur word of, met Kimberley as basis, op die grens van die Kaapkolonie en Betsjoeanaland optree. Daar is aanvaar dat die Transvaalse regering sowel die reserwe- as die aktiewe vrywilligers sal opkommandeer en dat verdere werwing toegelaat sou word. Só sou 5.500 soldate operasioneel betrek word, terwyl 'n verdere 2.000 troepe in Transvaal kon agterbly. Op hierdie wyse sou die kolonie nie heeltemal sonder georganiseerde eenhede wees nie.

Die inspekteur hei cius blooi 'n konsentrasieplan vir die T.V. ontwerp en van die veronderstelling uitgegaan dat die offisier, wat in bevel van 'n interkoloniale mag geplaas sou word, die Transvaalse troepe na goeddunke kon aanwend.

Die samestelling en sierkte van die Transvaal Volunteers en die beraamde tyd waarin hulle in Kimberley sou kon konsentreer, is soos volg bereken:

VOLG

NR.

\begin{tabular}{cccc}
\multicolumn{4}{c}{ SAAMGETREK TE } \\
KIMBERLEY \\
4 & 7 & 14 & 21 \\
dae & dae & dae & dae
\end{tabular}

1. Die Transvaal Horse Artillery. Twee batterye met vier kanonne elk.

2. Die Imperial Light Horse.

3. Die Northern Mounted Rifles.

400

450

4. Die Southern Mounted Rifles.

200

300

400

500

5. Die Central South African Railway Engineer Corps. (Genie).

150

300

400

500

6.

Die Central South African Railway Engineer Corps. (Infanterie).

Die Sig. \& Field Telegraph Company.

$\begin{array}{llll}30 & 40 & 50 & 60\end{array}$




\begin{tabular}{clrrrrr}
\hline \hline & & \multicolumn{5}{c}{ SAAMGETREK TE } \\
VOLG & & 4 & 7 & 14 & 21 \\
NR. & & dae & dae & dae & dae \\
& & & & & \\
& & 80 & 160 & 192 & 192 \\
11. & Die Cavalry Field Ambulance (drie afde- & & & 18 & 18 \\
12. & lings). & Die Veterinary Department. (Drie mobiele & 9 & 18 & 18 \\
& afdelings). & & & & \\
\hline & Totale : & 2.369 & 3.243 & 4.360 & 5.395 \\
\hline \hline
\end{tabular}

Die gepantserde treine, beman deur die Central South African Railway Engineer Corps en elkeen met een 12-ponder snelvuurkanon en twee maxims toegerus, sou in gereedheid gehou word in geval hulle benodig word. Een afdeling van die 15ponder artilleriebattery sou by die basis vir diens in gereedheid gehou word. Tot tyd en wyl die afdeling vir diens benodig word, sou artillerie-rekrute daardeur opgelei word.

Soos in die vorige skema sou die Imperiale Krygsbehoeftedepot versoek word om aanvullende ammunisie te voorsien.

Van die instelling van verantwoordelike bestuur, in Desember 1906, is veral vordering gemaak met die aankoop van kanonne vir die artilleriekorps.

Teen die einde van November 1907 het die Transvaalse regering ses 15-ponder agterlaaierkanonne teen $£ 876$ van die Imperiale regering gekoop.

Met die ontbinding van die Transvaal Volunteers (1912) het die mag oor die volgende kanonne beskik: Vier 13-ponder snelvuurkanonne, ses 15-ponder agterlaaierkanonne, drie 12-ponder vlootkanonne (in bruikleen van die Imperiale regering ontvang vir gebruik by gepantserde treine) en twee 1-ponder outomatiese snelvuurVickers-maximkanonne. 


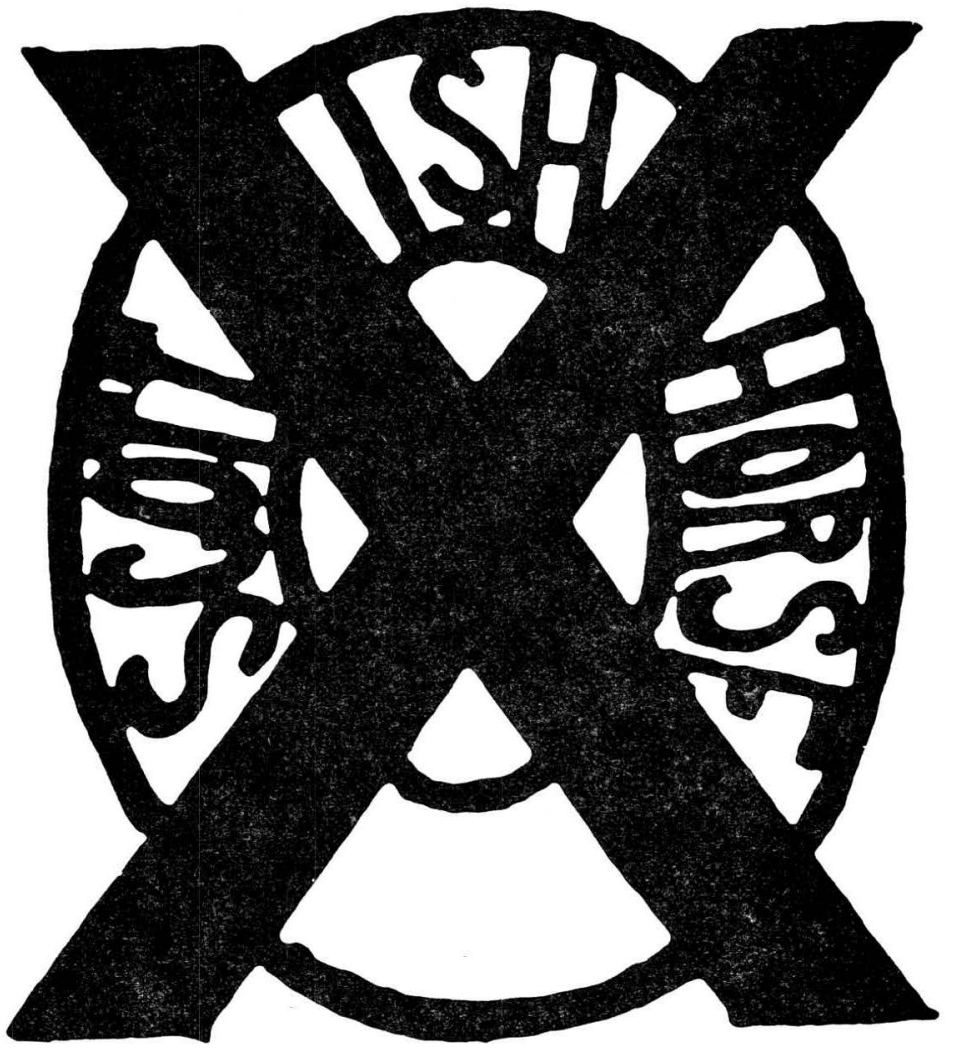

Petkenteken van die "Scottish Horse" wat in 1900 in gebruik geneem en tot die ontbinding van die eenheid, in 1907, gehandhaaf is. Latcre ontwerpe bevat die jaartal 1900 in die ovale gedeelte onderkant die kruis.

Foto : Versameling mnr. S. Foote, Pretoria M.H.A.D.

Cap badge of the "Scottish Horse", taken into use during 1900 and used until the disbandment of the unit in 1907. Later examples incorporated the year 1900 in the oval portion under the cross.

Photograph : Collection Mr. S. Foote, Pretoria M.H.A.S. 


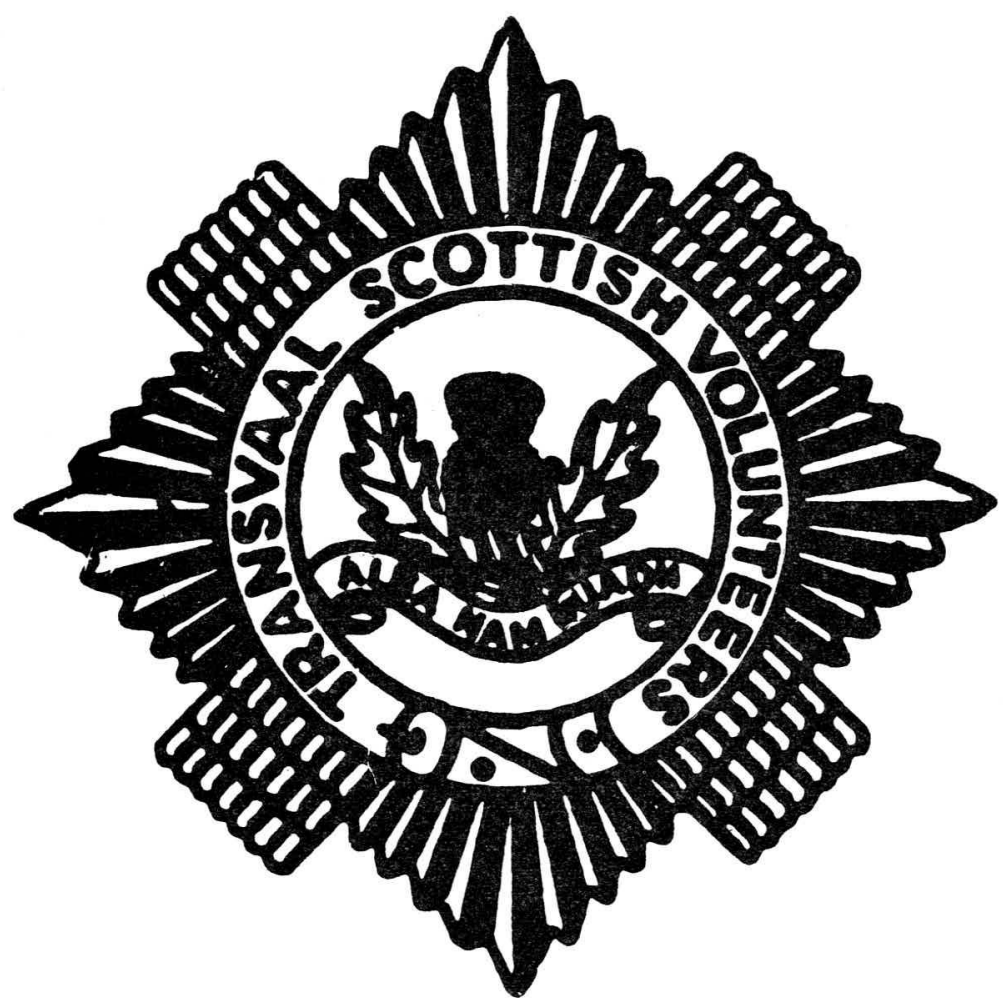

Die afgebeelde petkenteken van die "Transvaal Scottish Volunteers" is in 1902 deur 'n komitee ontwerp. Die middelste gedeelte, wat terselfdertyd diens gedoen het as 'n kraagkenteken vir offisiere, is gelyk aan die van 'n aantal "Highland"regimente. Dit is enigsins moeilik om die leuse in al sy betekenisse noukeurig te vertaal. By benadering beteken „Alba Nam Buadn” ewenwel „Goed gedoen, Skotland" en ,Skotland, tuiste van die deugde."

Foto: Versameling mnr. S. Foote, Pretoria M.H.A.D.

The cap badge of the "Transvaal Scottish Volunteers" depicted, was designed by a committee in 1902. The central portion, which at the same time served as a collar badge for officers, is similar to that of a number of Highland regiments. It is in any event difficult to translate accurately the motto which has a few meanings. However, "Alba Nam Buadn" could be translated as "Well done Scotland" and "Scotland, home of virtue."

Photograph : Collection Mr. S. Foote, Pretoria M.H.A.S. 


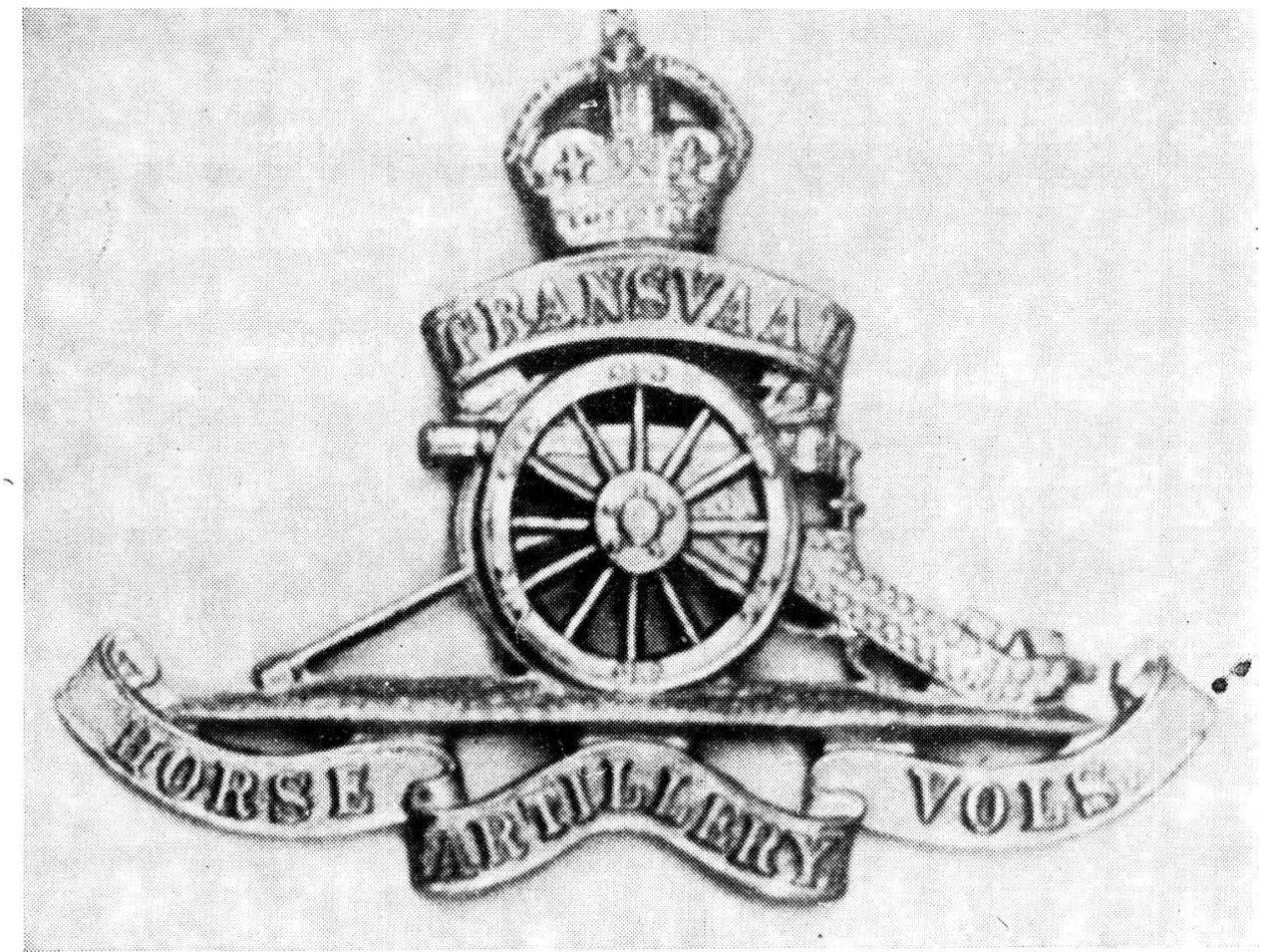

Kenteken van die Transvaal Horse Artillery Volunteers.

Foto : S.A. Weermagsargief M.H.A.D.

Badge of the Transvaal Horse Artillery Volunteers.

Photograph : S.A. Defence Force Archives M.H.A.S. 


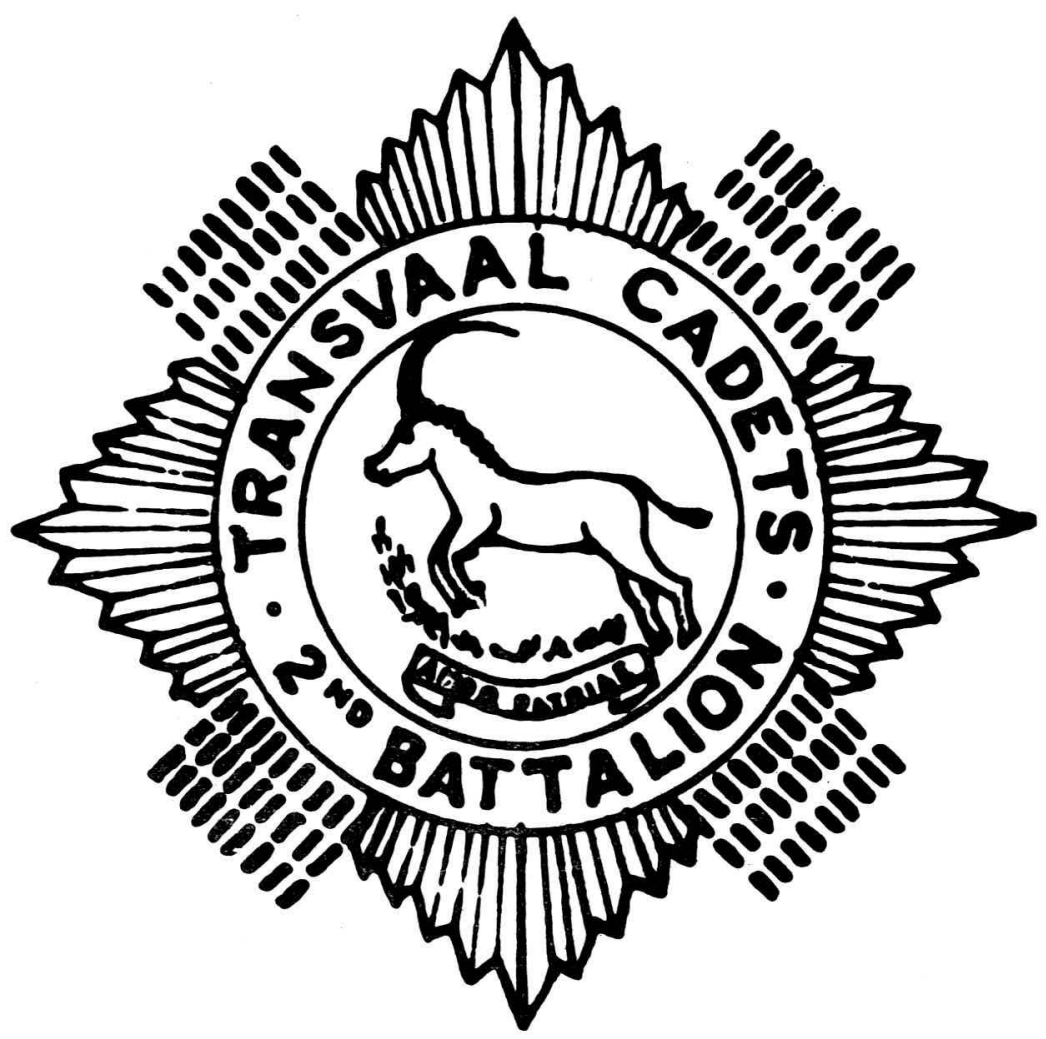

Petkenteken van die ,Transvaal Cadets"' (2e Bataljon) met 'n bewegende springbok en die leuse „Amor Patriae”, d.i. vaderlandsliefde.

Foto : Versameling mnr. S. Foote, Pretoria M.H.A.D.

Cap badge of the "Transvaal Cadets" (2nd Battalion) with a moving springbok and the motto "Amor Patriae", i.e. love of the Fatherland.

Photograph : Collection Mr. S. Foote, Pretoria M.H.A.S. 


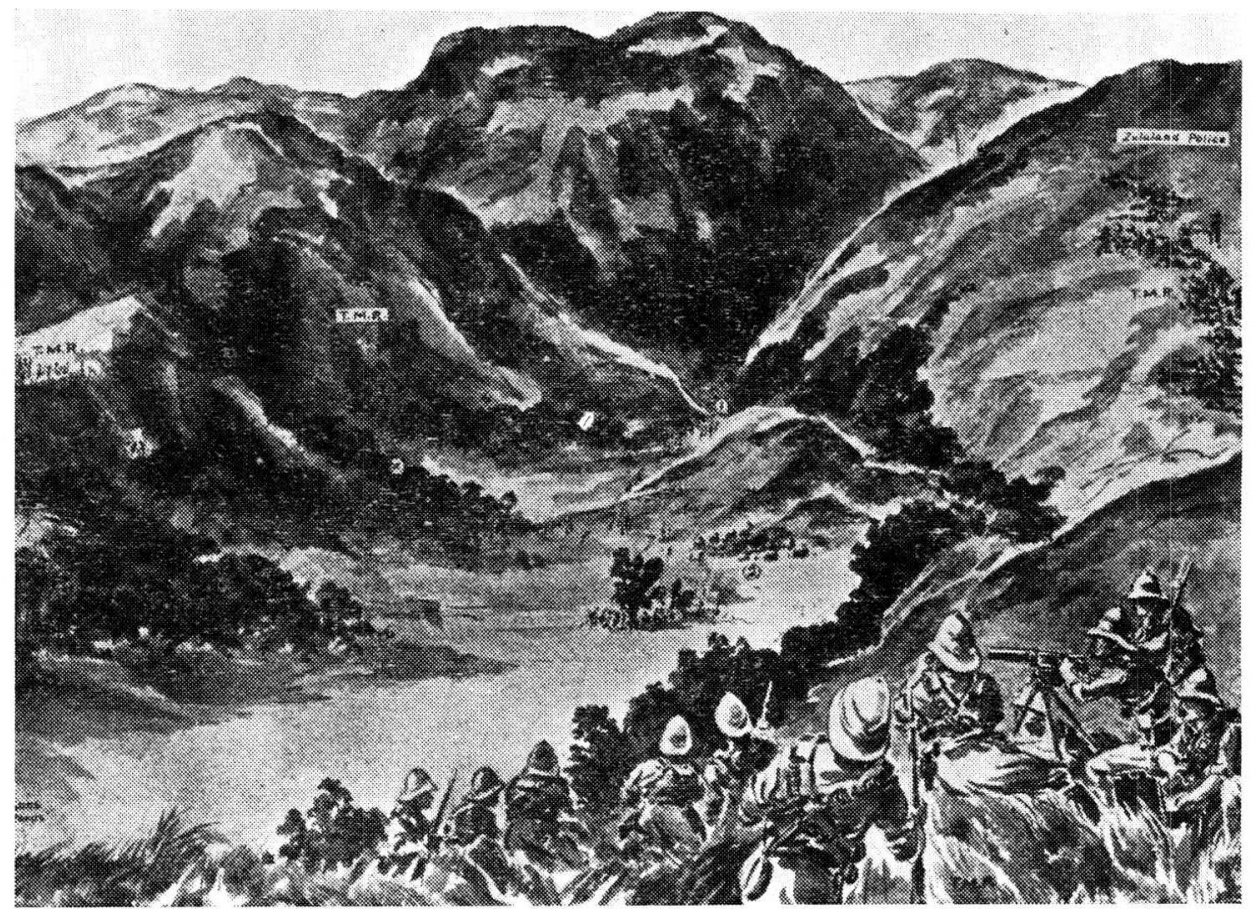

Die geveg van Momekloof (Zoeloerebellie, 1906).

1. Die nek wat toegang tot die hoër gedeelte van die kloof verleen.

2. Die posisie van die rebellekamp.

3. Die punt waar kapt. Mc Farlane gesneuwel het.

Opmerking: Die Natalse polisie was aan die linkerkant van die kloof, nader aan die veldkanonne, as die T.M.R.

Foto : Mnr. P. K. A. Digby, Pretoria

The Battle of Mome Gorge (Zulu Rebellion, 1906).

1. The nek which gives access to the upper part of the gorge.

2. Position of the rebel camp.

3. Spot where Capt. Mc Farlane was killed.

Note: The Natal Police were on the left of the gorge, nearer to the field guns than the T.M.R. 


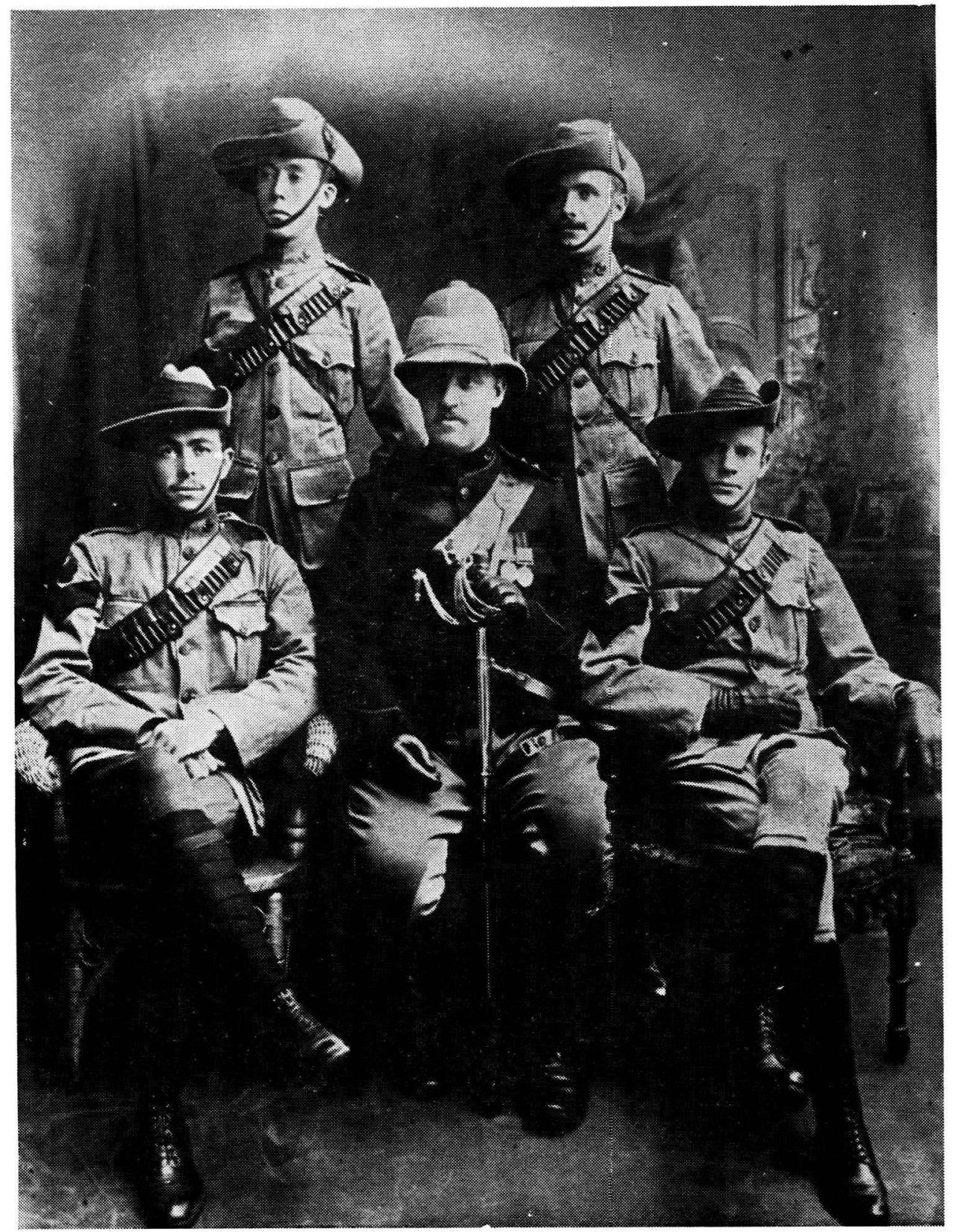

Groepfoto met lede van die „Northern Mounted Rifles,” Transvaal, wat omstreeks 1908 deur 'n onbekende afnemer geneem is.

Voor, van links na regs: Vaandelsersant J. G. Jeffery, luitenant Edwards-Carter, sersant T. E. Godfrey.

Agter, van links na regs : Sersant G. L. Bryant, sersant R. M. Crux.

Foto : S.A. Weermagsargief M.H.A.D.

Group photograph of members of the "Northern Mounted Rifles," Transvaal, taken by an unknown photographer about 1908 .

Front, left to right: Colour Sergeant J. G. Jeffery, Lieutenant Edwards-Carter, Sergeant T. E. Godfrey.

Rear, left to right : Sergeant G. L. Bryant, Sergeant R. M. Crux. 


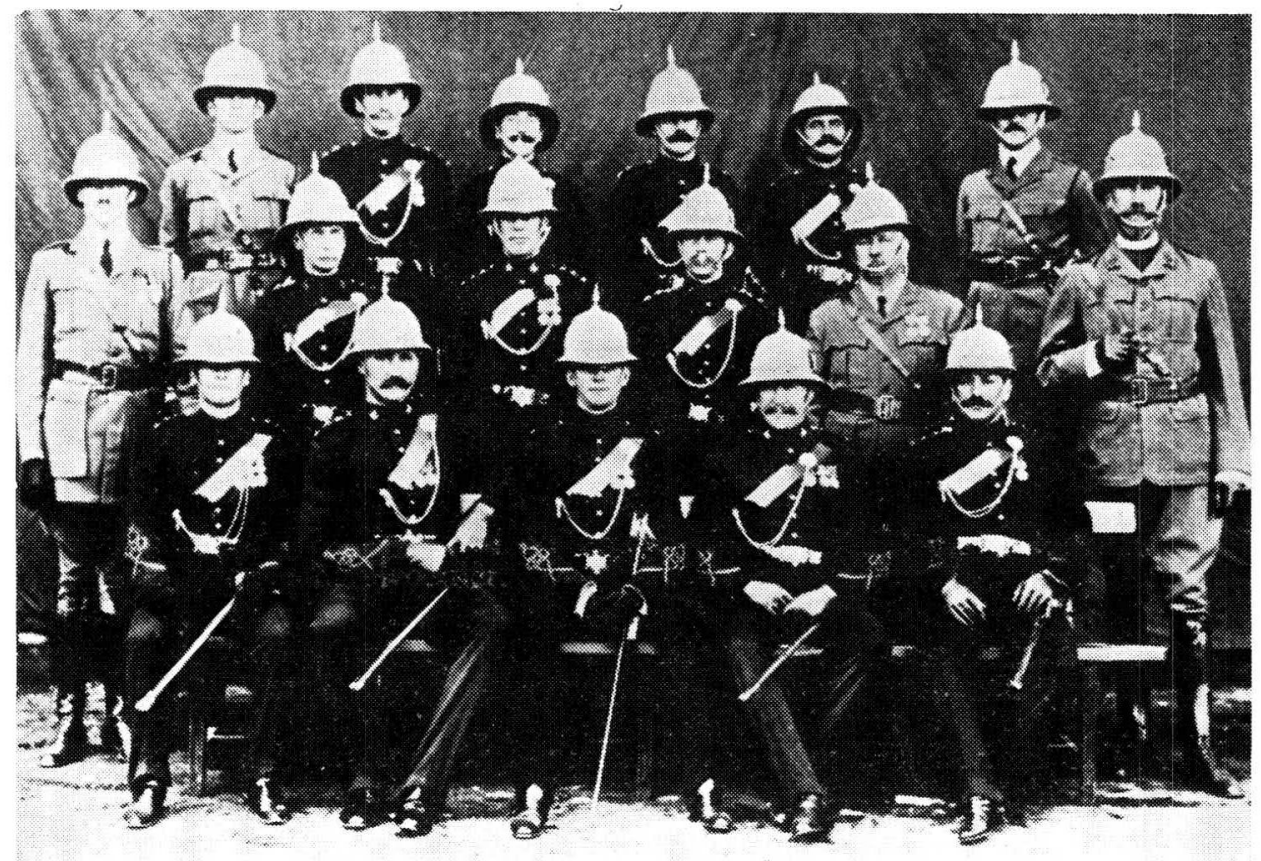

Lede van die „Regiment Witwatersrand Rifles.” Die foto is omstreeks 1911 geneem. Foto : S.A. Weermagsargief M.H.A.D.

Members of the "Regiment Witwatersrand Rifles." The photograph was taken about 1911.

Photograph : S.A. Defence Force Archives M.H.A.S. 


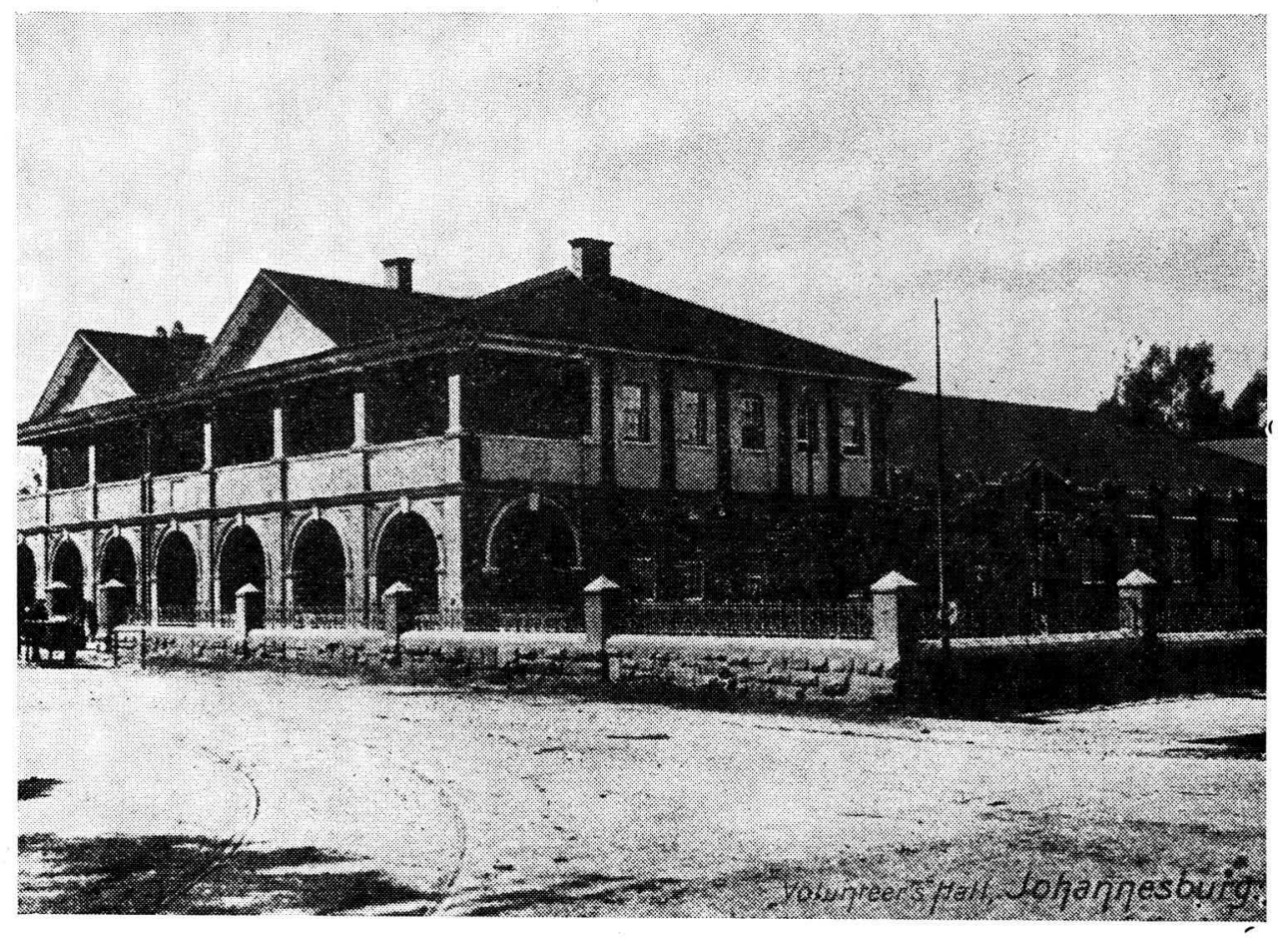

Die vroeëre hoofkwartier van die „Transvaal Volunteers,” Johannesburg. Vandag word die sogenaamde Drilsaal gebruik as die administratiewe hoofkwartier van die Kommandement Witwatersrand.

Foto: Maj. J. J. Kritzinger, Pretoria. M.H.A.D.

The former Headquarters of the "Transvaal Volunteers," Johannesburg. Today known as the Drill Hall, it serves as the administrative headquarters of the Witwatersrand Command.

Photograph : Maj. J. J. Kritzinger, Pretoria. M.H.A.S. 


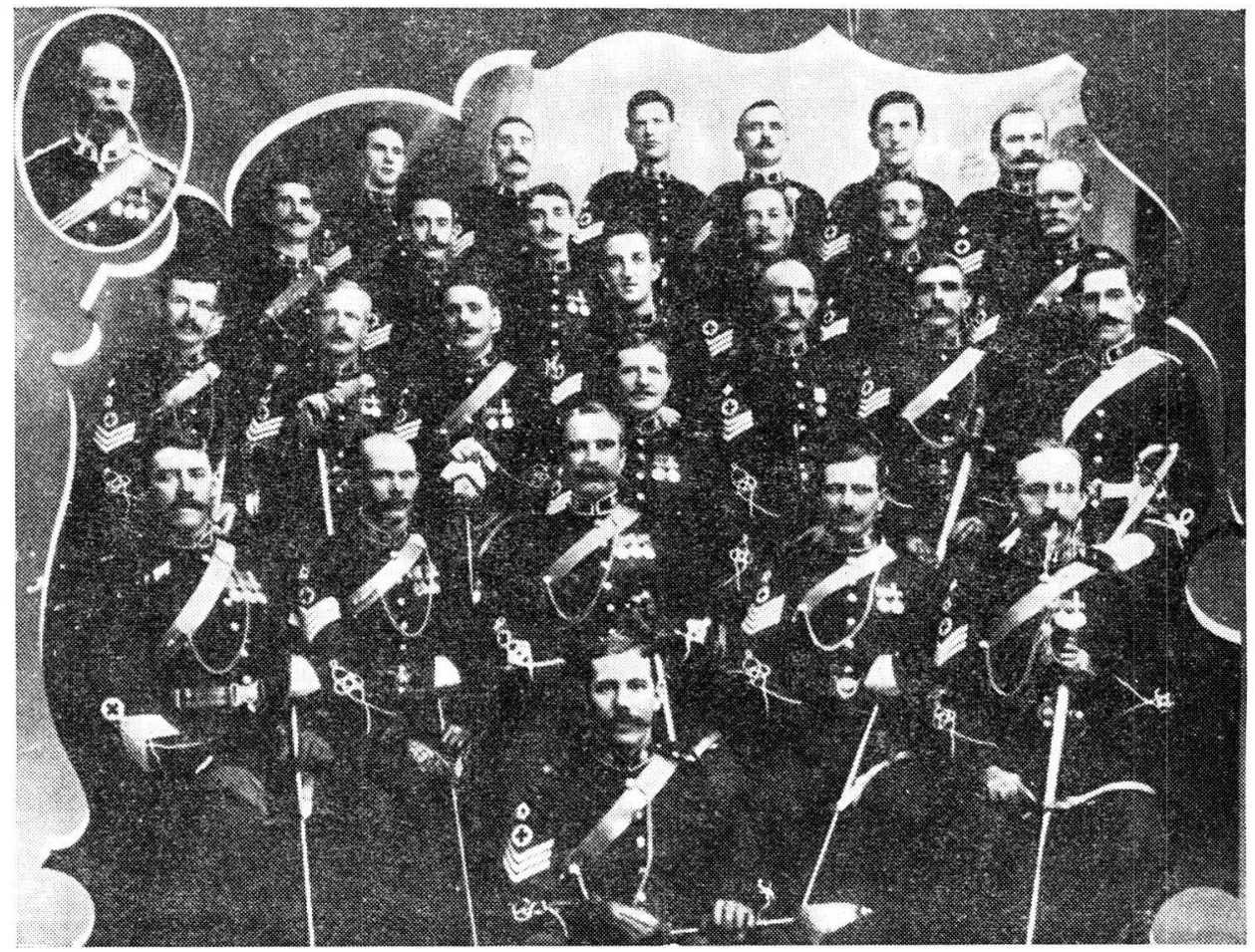

Groepfoto van die „Transvaal Volunteer Medical Staff” onder luitenant-kolonel D. H. Johnston as bevelvoerder.

Voorste ry: Stafsersant W. J. T. Cole.

Tweede ry, van links na regs : le klas stafsersant W. H. Dexter, sersant-instrukteur R. Cox, regiment sersant-majoor W. Higgins, sersant-instrukteur J. M. Maxwell, stafsersant W. J. Gordon.

Derde ry, van links na regs : Stafsersant J. Colebank, stafsersant C. E. Arlidge, stafsersant A. G. Mason, sersant E. F. W. Course, sersant T. Higginson, stafsersant J. Hopkinson, sersant-majoor Sumner (Cape Medical Corps, toegevoeg).

Vierde ry, van links na regs : Stafsersant J. J. Williams, sersant T. E. Davies, sersant I. Herson, sersant J. Allen, sersant J. Whiting, sersant E. Jacobs, stafsersant A. A. Robinson.

Vyfde ry, van links na regs : Sersant J. Levy, sersant T. Bryant, sersant J. M. Eaton, stafsersant W. F. Davies, sersant H. Gardiner, sersant E. A. Hale.

Inlas : Luitenant-kolonel D. H. Johnston.

Foto : Gannon en Kie, Johannesburg M.H.A.D.

Group photograph of the "Transvaal Volunteer Medical Staff" under Lieutenantcolonel D. H. Johnston as Commanding Officer :

Front row : Staff Sergeant W. J. T. Cole.

Second row, from left to right : 1st class Staff Sergeant W. H. Dexter, Sergeant Instructor R. Cox, Regimental Sergeant Major W. Higgins, Sergeant Instructor J. M. Maxwell, Staff Sergeant W. J. Gordon.

Third row, from left to right: Staff Sergeant J. Colebank, Staff Sergeant Arlidge, Staff Sergeant A. G. Mason, Sergeant E. F. W. Course, Sergeant T. Higginson, Staff Sergeant J. Hopkinson, Sergeant Major Sumner (Cape Medical Corps, attached).

Fourth row, from left to right : Staff Sergeant J. Williams, Sergeant T. E. Davies, Sergeant I. Herson, Sergeant J. Allen, Sergeant J. Whiting, Sergeant E. Jacobs, Staff Sergeant A. A. Robinson.

Fifth row, from left to right : Sergeant J. Levy, Sergeant T. Bryant, Sergeant J. M. Eaton, Staff Sergeant W. F. Davies, Sergeant H. Gardiner, Sergeant E. A. Hale. Insert: Lieutenant-Colonel D. H. Johnston. 


\section{7}

\section{KADETORGANISASIE}

Die kadetorganisasie in die Transvaal-kolonie was van sy ontstaan af onder regstreekse militêre beheer van die kommandant van die Transvaal Volunteers.

Weens gebrek aan bronne kon die aanvanklike organisasie nie in besonderhede nagespoor word nie. Wat wel afgelei kon word, is dat tot Augustus 1904 die volgende korpse en kompanies gestig is: Die Boys Brigade-kadetkorps, wat klaarblyklik gedurende Julie 1903 ingestel en gedurende September van dieselfde jaar deur die Transvaalse regering oorgeneem is (dit het die hele Witwatersrand as werwingsgebied gehad en het bestaan uit seuns wat reeds die skool verlaat het); die Jewish Lad Brigude-kudetkorps (gestig 22.2.1904) saamgestel uit Joodse skoolseuns in Johannesburg en aan die Witwatersrand, die kadetkorps van die Jeppestown High School (gestig 1.7.1903), drie kompanies van die Marist Brothers-kadette (gestig 14.4.1904), die kadetkorps van die Johannesburg College (gestig 1.7.1904), die kadetkorps van die Turffontein Government School (gestig 1.7.1904), die kadetkorps van die Mayfair Government School (gestig 1. 8. 1904), die kadetkorps van die Troyeville Government School (gestig 1.8.1904), die kadetkorps van die Roodepoort Government School (gestig 1.8.1904), en die kadetkorps van die Springs Government School (gestig 1.8.1904).

Aanvanklik is kadetkorpse om ekonomiese redes aan aktiewe vrywilligerkorpse verbind, maar omdat hierdie reëling nie geslaag het nie, is na 'n distriksorganisasie oorgeskakel.

Met ingang van 3 Augustus 1904 is die kadette amptelik volgens die bataljonstelsel georganiseer. Hiervolgens is daar vier kadetbataljons ingestel.

Die eerste bataljon is gevorm en het bestaan uit die verskillende gemagtigde kompanies van die Boys Brigade Cadet Corps as kern. Lede daarvan was na-skoolse seuns aan die Witwatersrand.

Die tweede bataljon is saamgestel uit gemagtigde kompanies aan skole en kolleges in 'n gedeelte van Johannesburg en die Oos-Rand. Die bestaande kompanies van Marist Brothers School en Jeppestown High School was die aanvanklike kern van hierdie korps.

'n Derde bataljon is gevorm met as kern die bestaande kompanies van die Jewish Lads Brigade. Hierdie bataljon het 'n gedeelte van Johannesburg en die Wes-Rand as werwingsgebied gehad.

Die vierde bataljon het bestaan uit die kadetkompanies wat na 3 Augustus 1904 in die distrik Pretoria ingestel is.

'n Duidelike beeld van die bataljonorganisasie word uit onderstaande verspreidingsopgawes van 25 Oktober 1905 verkry: 
1ste BAT ALJON

WITW ATERSRAND

\begin{tabular}{clr}
\hline $\begin{array}{c}\text { KOMPANIE- } \\
\text { NR. }\end{array}$ & \multicolumn{1}{c}{ WERWINGSGEBIED } & $\begin{array}{r}\text { AANTAL } \\
\text { KADETTE }\end{array}$ \\
\hline 1. "A" & Johannesburg (stad) & 92 \\
2. "B" & Jeppestown & 149 \\
3. "C" & Braamfontein & 56 \\
4. "D" & Krugersdorp & 64 \\
5. "E" & Fordsburg & 41 \\
6. "F" & Ophirton en Turffontein & 46 \\
7. "G" & Boksburg en Springs & 56 \\
8. "H" & Germiston & 84 \\
& Totaal & 588 \\
\hline \hline
\end{tabular}

2de BAT ALJON

JOHANNESBURG

\begin{tabular}{clc}
\hline $\begin{array}{c}\text { KOMPANIE- } \\
\text { NR. }\end{array}$ & \multicolumn{1}{c}{ WERWINGSGEBIED } & AANTAL \\
KADETTE \\
\cline { 2 - 3 } A. & Die Marist Brothers School & 90 \\
B. & Die Marist Brothers School & 90 \\
C. & Die Marist Brothers School & 90 \\
D. & Die Jeppestown High School & 80 \\
E. & Die Johannesburg College & 80 \\
F. & Die Mayfair Government School & 120 \\
G 1. & Die Turffontein Government School & 76 \\
G 2. & Die Booysens Government School & 60 \\
H. & Die Troyeville Government School & 70 \\
I. & Die City and Suburban Government School & 64 \\
- & Die Jewish Government School & 55 \\
& & \\
& Totaal & 875 \\
\hline \hline
\end{tabular}

$O O S-R A N D$

\begin{tabular}{ccc}
\hline $\begin{array}{c}\text { KOMPANIE- } \\
\text { NR. }\end{array}$ & WERWINGSGEBIED & AANTAL \\
KADETTE \\
- & Die Germiston Government School & 26 \\
- & Die Boksburg Government School & 24 \\
& Totaal & 50 \\
\hline \hline
\end{tabular}


3de BATALJON

\begin{tabular}{clc}
$\begin{array}{c}\text { KOMPANIE- } \\
\text { NR. }\end{array}$ & \multicolumn{1}{c}{ WERWINGSGEBIED } & $\begin{array}{r}\text { AANTAL } \\
\text { KADETTE }\end{array}$ \\
\hline- & Maraisburg & 42 \\
- & Florida & 46 \\
- & Roodepoort & 49 \\
- & Randfontein & 30 \\
- & Modderfontein & 42 \\
- & Die Union Ground School, Johannesburg & 64 \\
- & Die Jeppestown School & 67 \\
- & Die Von Brandis School & 23 \\
- & Die Braamfontein School & 29 \\
& Totaal & 392 \\
\hline
\end{tabular}

4de BATALJON

PRETORIA

\begin{tabular}{clc}
\hline $\begin{array}{c}\text { KOMPANIE- } \\
\text { NR. }\end{array}$ & \multicolumn{1}{c}{ WERWINGSGEBIED } & $\begin{array}{c}\text { AANTAL } \\
\text { KADETTE }\end{array}$ \\
\hline "A" & Die Diocesan College School & 60 \\
"B" & Die Gymnasium School en die Burgher Right School & 97 \\
"C" & $\begin{array}{l}\text { Die East Rand School, Gezina School en die Miriam } \\
\text { Marks School }\end{array}$ & 79 \\
& Totaal & $\mathbf{2 3 6 *}$ \\
\hline
\end{tabular}

Die sterkte van 'n bataljon was dieselfde as in die vrywilligerregulasies vir ' $n$ infanteriekorps voorgeskryf was, dus 'n maksimum en minimum sterkte van 808 seuns en 476 seuns. 'n Bataljon het volgens hierdie voorskrifte uit vier kompanies bestaan.

'n Stafoffisier, in 1905 die adjudant van die Transvaal Scottish Volunteers, was aan die kommandant van die T.V. vir die administrasie van die kadetorganisasie verantwoordelik. Hy is deur vier adjudante, een vir elke bataljon, bygestaan. Die adjudante is deur sersant-instrukteurs bygestaan.

Vroeg in Oktober 1905 het die kommandant van die Transvaal Volunteers die volgende voorstelle vir die reorganisasie van die kadette aan die Transvaalse Koloniale Sekretaris voorgelê:

Die bataljonstelsel moes afgeskaf word en deur 'n kompaniestelsel vervang word. Kompanies moes 'n afsonderlike nommer kry.

Die hele organisasie moes onder die naam van Transvaal Cadets bekend staan.

* Hierdie verspreidingsopgawes toon nie al die kadetkompanies wat reeds teen 25 Oktober 1905 ingestel was nie. Die rede hiervoor is dat teen die einde van Junie 1905 in die praktyk reeds begin is om die kadette volgens kompanies in distrikte te organiseer. 
Organisatories moes Transvaal in vier afdelings ingedeel word, t.w.: Johannesburg, 'n oostelike-, 'n noordelike- en 'n westelike afdeling. Die kadetkompanies in die noordelike, oostelike en westelike afdelings moes vir instruksiedoeleindes onderskeidelik aan die Northern, Eastern en Western Rifles toegevoeg word en moes onder toesig van die bevelvoerende offisiere van hierdie korpse geplaas word. Aan die kompanies van die Johannesburgse afdeling moes spesiale instrukteurs van die permanente staf vir opleidingsdoeleindes beskikbaar gestel word. Alle kadette moes dieselfde uniform, nl. 'n donkerbruin broek, hemp en trui, met 'n slap breërandhoed, dra. Die dienste van vier bataljon-adjudante moes beëindig word, en in hulle plek moes die hoofkwartier-staf een stafoffisier vir kadette aangestel word. Hierdie offisier moes regstreeks aan die kommandant van die Transval Volunteers vir die administrasie van die kadetorganisasie verantwoordelik wees. Groter skole kon hulle eie kompanie of kompanies hê, terwyl vir na-skoolse seuns afsonderlike kompanies ingestel moes word.

Hierdie skema het die volgende voordele ingehou: die organisasie sou eenvormiger wees, eenvormige uniforms vir alle kadette sou tot gevolg hê dat senior- sowel as junior kadetkompanies op enige plek in Transvaal ingestel kon word sodra die getalle dit regverdig, die oorplasing van kadette van een kompanie na 'n ander sou geen onkoste meebring nie, en naywer tussen die kadette van die verskillende bataljons sou uitgeskakel word.

In Oktober 1905 het die Transvaalse Koloniale Sekretaris die voorgestelde skema goedgekeur. Op 1 November 1905 is lt.-kol. R. P. Macdonald, D.S.O., in die hoedanigheid van Staff Officer Cadets aangestel om die skema in werking te stel.

Teen die helfte van 1906 was die reorganisasie afgehandel en was die Transvaalse kadette in vier-en-vyftig afsonderlike kompanies georganiseer.

Teen die einde van die Kroonkolonie-tydperk het die kadetorganisasies soos volg daar uitgesien:

\begin{aligned} \hline \hline $\begin{array}{r}\text { KOMP. } \\ \text { NR. }\end{array} &$ NAAM VAN KOMPANIE* & $\begin{array}{r}\text { DATUM VAN } \\ \text { INSTELLING }\end{array} & \begin{array}{c}\text { HOOF- } \\ \text { KWARTIER }\end{array} \\$\hline 1. & Jeppestown & 1.7 .1903 & Jeppestown \\ 2. & Germiston & 1.7 .1903 & Germiston \\ 3. & Clifton & 1.7 .1903 & Johannesburg \\ 4. & Krugersdorp & 1.7 .1903 & Krugersdorp \\ 5. & Boksburg & 1.7 .1903 & Boksburg \\ 6. & St. Mary's & 1.7 .1903 & Johannesburg \\ 7. & Cleveland & 1.7 .1903 & Johannesburg \\ 8. & Pretoria, O.S & 1.5 .1906 & Pretoria \\ 11. & Marist Bros & 14.4 .1904 & Johannesburg \\ 12. & Marist Bros & 14.4 .1904 & Johannesburg \\ 13. & Marist Bros & 14.4 .1904 & Johannesburg \\ 14. & Jeppestown High School & 1.7 .1903 & Jeppestown \\ 15. & Johannesburg College & 1.7 .1904 & Johannesburg \\ 16. & Mayfair Government School & 1.8 .1904 & Fordsburg \\ 17. & Mayfair Government School & 1.8 .1904 & Fordsburg \\ 18. & Turffontein Government School & 1.7 .1904 & Turffontein \\ 19. & Booysens Government School & 21.1 .1905 & Booysens \\ 20. & Troyville Government School & 1.8 .1904 & Troyville \\ 21. & City and Suburban & 1.9 .1904 & Johannesburg \\ 22. & Germiston & 15.8 .1904 & Germiston \end{aligned}




\begin{tabular}{|c|c|c|c|}
\hline $\begin{array}{l}\text { KOMP. } \\
\text { NR. }\end{array}$ & NAAM VAN KOMPANIE* & $\begin{array}{l}\text { DATUM VAN } \\
\text { INSTELLING }\end{array}$ & $\begin{array}{c}\text { HOOF- } \\
\text { KWARTIER }\end{array}$ \\
\hline 23. & Boksburg & 15. 8.1904 & Boksburg \\
\hline 24. & Jewish Government School & 15. 8.1904 & Johannesburg \\
\hline 25. & Jeppestown Government School & 25. 6.1905 & Jeppestown \\
\hline 26. & Maraisburg & 1. 9.1904 & Maraisburg \\
\hline 27. & Florida & 1. 9.1904 & Florida \\
\hline 28. & Roodepoort Government School & 1. 8.1904 & Roodepoort \\
\hline 29. & Randfontein & 1. 9.1904 & Randfontein \\
\hline 30. & Modderfontein & 23.11.1904 & Modderfontein \\
\hline 31. & Union Ground & 1. 2.1905 & Johannesburg \\
\hline 32. & Von Brandis Square & 1. 2.1905 & Johannesburg \\
\hline 33. & Spes Bona & 1. 9.1905 & Braamfontein \\
\hline 34. & Zuurfontein & 1. 2.1905 & Zuurfontein \\
\hline 35. & Avenue Government School & 1. 9.1904 & Braamfontein \\
\hline 36. & Diocesan College & 23.11.1904 & Pretoria \\
\hline 37. & Gymnasium College & 22.11 .1904 & Pretoria \\
\hline 38. & East Rand School & 22. 4.1906 & Pretoria \\
\hline 39. & Gezina School & 22.11.1904 & Pretoria \\
\hline 40. & Miriam Marks School & 4. 4.1905 & Pretoria \\
\hline 41. & Cullinan Government School & 28. 8.1906 & Cullinan \\
\hline 42. & Pietersburg Free School & 30.11 .1905 & Pietersburg \\
\hline 43. & Pietersburg Secondary School & 30.11 .1905 & Pietersburg \\
\hline 44. & Potgietersrust Government School & 1. 1.1906 & Potgietersrust \\
\hline 45. & Milner Upper School & 1. 2.1906 & Klerksdorp \\
\hline 46. & Burgher Right Erven & 1.11 .1905 & Pretoria \\
\hline 47. & Heidelberg & 1. 7.1905 & Heidelberg \\
\hline 48. & Barberton & 21. 8.1905 & Barberton \\
\hline 49. & Standerton & 29. 8.1905 & Standerton \\
\hline 50. & Volksrust & 15. 8.1905 & Volksrust \\
\hline 51. & Wakkerstroom & 16.11.1905 & Wakkerstroom \\
\hline 52. & Potchefstroom & 1. 8.1905 & Potchefstroom \\
\hline 53. & Springs Government School & 1. 8.1904 & Springs \\
\hline 55. & Mayville School & 1.12 .1905 & Pretoria \\
\hline 56. & Rustenburg Government School & 1. 3.1906 & Rustenburg \\
\hline 57. & Middelburg & 1. 3.1906 & Middelburg \\
\hline
\end{tabular}

Hierdie vorm van organisasie was nie heeltemal bevredigend ten opsigte van die senior kadette nie en reeds in September 1907 is hulle weer in 'n afsonderlike bataljon georganiseer. Die beweegredes hiervoor was die volgende: Onder die kompanieorganisasie was dit moeilik om geskikte na-skoolse seuns van veertien jaar en ouer te werf. Hierdie seuns was nie gediend met die idee om dieselfde uniform en gewere te gebruik as dié wat aan skoolseuns uitgereik is nie. Tewens sou die samesnoering van die seniorkompanies tot 'n bataljon eintlik geen bykomende koste vir die regering tot gevolg hê nie, en die bataljon sou nog deur die Staff Officer Cadets beheer word. Verder sou die samesnoering van na-skoolse seuns in die bataljon uit die aard van die saak nie weer die naywer wat tussen die vroeëre kadetbataljons bestaan het, laat herlewe nie.

Die voorgestelde naam vir die nuwe bataljon was First Cadet Battalion Witwatersrand Rifles, en die funksies van hierdie bataljon sou veral wees om rekrute vir die Witwatersrand Rifles te voorsien.

* Hiervan was ses kompanies senior oftewel na-skoolse kadette. 
Met ingang van 18 September 1907 is die First Cadet Battalion Witwatersrand Rifles uit nrs. 1, 2, 3 ,5, 6 en 10 kadetkompanies en met 'n goedgekeurde sterkte van 600 kadette, alle range inbegrepe, ingestel.

In die loop van 1908 is die ouderdomsgrens van lede van hierdie bataljon van agtien na een-en-twintig jaar verhoog.

In Maart 1908 was uit 'n totale sterkte van 400 lede 150 lede van die bataljon ouer as sewentien, terwyl 100 ouer as agtien jaar was. Volgens bestaande regulasies het laasgenoemde groep reeds die leeftydsgrens bereik en moes hulle as kadette ontslaan word. Hierdie groep was feitlik sonder uitsondering goed opgelei en daarby bereid om 'n eed van getrouheid af te lê waarkragtens hulle vir aktiewe diens beskikbaar sou wees. Indien hulle op agtienjarige ouderdom as kadette ontslaan moes word, sou hulle nie bereid wees om dadelik by 'n vrywilligerkorps aan te sluit nie. Hierdeur sou hulle opleiding dus op 'n ongewenste tydstip onderbreek word.

Indien die ouderdomsbeperking vir senior kadette nie van agtien na een-en-twintig jaar opgeskuif sou word nie, sou hierdie korps eintlik nie aan sy doel beantwoord nie. Die korps was juis ingestel om voorsiening te maak vir die militêre opleiding van seuns vandat hulle die skool verlaat het totdat hulle gereed sou wees vir toetrede tot ' $n$ aktiewe korps. Bewus van die feit dat seuns tussen agtien en een-entwintig jaar kwalik as kadette beskou kan word, het die bevelvoerder van die bataljon voorgestel dat die bataljon nie as 'n senior kadetkorps nie, maar eerder as 'n junior vrywilligerkorps moet funksioneer. Hy het verder voorgestel dat almal met ouderdomme van sewentien tot een-en-twintig jaar 'n eed van getrouheid moes aflê, waarkragtens hulle vir aktiewe diens beskikbaar sou wees.

Die verhoging van die ouderdomsgrens sou tot gevolg hê dat seuns wat hulle kadetopleiding saam voltooi het, toegelaat sou word om ook verdere militêre opleiding saam te ontvang. Hierdeur sou 'n gees van kameraadskap tussen die jong manne bevorder word. Skoolkadette sou dus na skoolverlating na die seniorkorps oorgeplaas word, waar hulle van vier tot vyf jaar verdere en meer gevorderde opleiding sou ontvang. Op 'n ouderdom van een-en-twintig sou hulle as goed opgeleide jong manne maklik by die verskillende vrywilligerkorpse ingedeel kon word.

Die nadeel verbonde aan 'n ouderdomsbeperking van agtien jaar was dat kadette van hierdie ouderdom gewoonlik net so 'n stadium in hulle opleiding bereik het waarin hulle kon begin behulpsaam wees met die opleiding van jongere kadette. Die vernaamste rede waarom die beste lede van hierdie groep nie by vrywilligerkorpse wou aansluit nie, was dat hulle, wat reeds as onderoffisiere gedien het, as onderoffisiere nie graag weer as manskappe tot 'n aktiewe vrywilligerkorps wou toetree nie.

'n Baie belangrike rede vir die verhoging van die ouderdomsgrens was dat die meeste vrywilligerkorpse gedurende 1908 op volle sterkte was en dat die plan op daardie stadium juis was om die goedgekeurde sterkte van die verskillende korpse te verminder. Die kadette wat op agtienjarige ouderdom uit die organisasie moes tree, sou nie in vrywilligerkorpse opgeneem word nie.

Met ingang van 16 Julie 1908 het die kadetorganisasie die volgende veranderinge ondergaan: Kadette is formeel in drie kategorieë ingedeel, t.w. (a) senior kadette, (b) skoolkadette, tussen veertien en agtien jaar, en (c) skoolkadette wat nie met gewere uitgerus is nie, dus jonger as veertien jaar. 
Die ouderdomsgrens vir senior kadette is op een-en-twintig vasgestel en by bereiking van hierdie ouderdom moes hulle die eed van getrouheid aflê, waarkragtens hulle vir aktiewe diens opgeroep kon word. Verder sou kadette wat die neergelegde ouderdomsgrens bereik het, ontslaan word, mits dit hulle begeerte was om na 'n aktiewe vrywilligerkorps oorgeplaas te word. Tewens is afsonderlike voorskrifte vir dril- en skietoefeninge en individuele toelaes vir senior kadette neergelê.

Die strenge handhawing van die ouderdomsgrens van agtien jaar vir skoolkadette is in 1909 in Transvaal opgehef. Aanleiding hiertoe was dat gedurende dié jaar daar heelwat voltydse leerlinge aan die Potchefstroom Industrial School en ander hoërskole en kolleges was wat aan kadetkompanies verbonde was en ouer as agtien jaar was. Onder hierdie omstandighede het die Inspekteur van die Transvaal Volunteers die Koloniale Sekretaris genader met die versoek dat bona fide-leerlinge wat ouer as agtien jaar was, aan kadetkompanies van dié inrigtings waar hulle studeer, verbonde moet bly, solank hulle aan dié inrigtings onderrig word.

Die belangrikste beweegrede vir hierdie versoek van die Inspekteur van die T.V. was dat, volgens die regulasies wat toe in Transvaal van toepassing was, skoolkadette, nadat hulle agtien jaar geword het maar nog voltyds aan hoërskole of kolleges onderrig is, verplig was om hulle bande met die kadetkompanies van hierdie inrigtings te verbreek. Aan die ander kant kon senior kadette tot op een-entwintig jaar in senior kadetkorpse bly dien. Die inspekteur se voorstel het neergekom op 'n uitbreiding van die senior kadetkorps in Transvaal. Tot op hierdie tydstip was die senior kadetkorps tot een bataljon, die First Cadet Battalion Witwatersrand Rifles, beperk. 'n Tweede bataljon senior kadette moes, volgens die inspekteur, ingestel word. Hierdie bataljon moes bestaan uit alle senior kadette wat nie lede van die First Cadet Battalion Witwatersrand Rifles was nie. Die voorgestelde bataljon sou dus eerstens bestaan uit verskillende kompanies na-skoolse senior kadette tussen veertien en een-en-twintig jaar wat buite die Witwatersrandgebied woonagtig was. Tweedens sou voltyds skoolgaande senior kadette tussen agtien tot eenen-twintig jaar, wat tot skoolkompanies toegevoeg moes word, lede wees.

Die Koloniale Sekretaris van Transvaal was klaarblyklik beïnvloed deur die aanbevelings van die Durbanse konferensie van Oktober 1908, nl. dat kadette ontslaan moet word sodra hulle kwalifiseer vir aansluiting by aktiewe korpse, d.w.s. op agtienjarige ouderdom. Hy het beslis dat geen senior kadetorganisasies, anders as die First Cadet Battalion Witwatersrand Rifles, toegelaat sal word nie en dat senior kadette buite die Witwatersrandgebied alleen toegelaat sou word indien hulle ouer as agtien jaar was en voltydse leerlinge aan 'n skool of kollege was. Verder is bepaal dat voltydse leerlinge wat aan skole of kolleges, tussen agtien en een-en-twintig jaar wat vir praktiese opleidingsdoeleindes tot skoolkompanies toegevoeg is, maar in alle ander opsigte volgens die regulasievoorskrifte vir senior kadette behandel moes word. Hulle het trouens 'n deel van die sterkte van die First Cadet Battalion Witwatersrand Rifles uitgemaak en moes as lede van die bataljon geadministreer word.

$\mathrm{Na}$ die reorganisasie van die kadette in kompanies het die organisasie soos volg ontwikkel. Die volgende skoolkadetkompanies is ingestel: No. 65 Company Transvaal Cadets, te Rustenburg (1.11.1908); No. 66 Company Transvaal Cadets, te Nylstroom (18.12.1908); No. 67 Company Transvaal Cadets, te Christiana (1.3.1909).

Die volgende skoolkadetkompanies is ontbind: No. 52 Company Transvaal Cadets 
Company Transvaal Cadets, te Rustenburg (16.9.1908). Die naam van skoolkadetkompanie No. 4 Company Transvaal Cadets is met ingang van 18 September 1907 na No. 9 Company Transvaal Cadets verander.

Seniorkadetkompanies wat ingestel is, was die volgende: No. 4 Company First Cadet Battalion, Witwatersrand Rifles, te Krugersdorp (18.9.1907); No. 6 Company First Cadet Battalion, Witwatersrand Rifles, te Benoni (1.7.1908) en No. 7 Company Ist Cadet Battalion, Witwatersrand Rifles, te Krugersdorp (1.8.1908). 


\section{SLOTBESKOUING}

In die daarstelling van 'n permanente verdedigingsorganisasie in Transvaal na die Anglo-Boere-oorlog het finansiële oorwegings 'n groot rol gespeel. Die groot koste verbonde aan die onderhoud van die sterk garnisoen Britse troepe wat na die oorlog in Transvaal agtergebly het, het by die Britse regering die voorneme laat ontstaan om hierdie garnisoen drasties te verklein. Brittanje wou ook oor die moontlikheid beskik om 'n groot deel van die troepe te onttrek, indien hulle elders vir oorlogsdiens benodig sou word. Die plek van hierdie troepe sou dan deur Transvaalse troepe gevul moes word, anders sou die kolonie nie sy binnelandse veiligheid kon behartig nie.

Die South African Constabulary, 'n polisiemag wat gedurende die Anglo-Boereoorlog gestig is, het weliswaar in ' $n$ mate in die behoefte aan binnelandse beveiliging van Transvaal voorsien, maar omrede dit 'n permanente mag was, was die onderhoudskoste hoog, terwyl uitbreiding daarvan na die oorlog nie binne die finansiële vermoë van die Transvaal-kolonie was nie.

Onder hierdie omstandighede was die enigste oplossing die daarstelling van 'n militêre organisasie wat die Transvaalse regering goedkoper sou uitkom. Die voor die hand liggende oplossing was dus 'n vrywilligerstelsel. Op dié wyse sou die koste deels deur die regering en deels deur vrywilligers self gedra word.

Die politieke omstandighede waaronder die nuwe verdedigingsmag tot stand gekom het, was daarvoor verantwoordelik dat daar doelbewus na gestrewe is om die Boerebevolking van die nuwe organisasie uit te sluit. Die rede hiervoor was die vrees wat by die nuwe bewindhebbers bestaan het dat die Boere, sodra hulle weer toegelaat sou word om te bewapen, dalk tot opstand sou kon oorgaan.

Dit Witwatersrandse gebied was die aangewese plek om met 'n vrywilligerorganisasie te begin. Die bevolking van dié gebied was oorwegend pro-Brits. Verder het die meerderheid van die Uitlanders wat voor die uitbreek van die oorlog hier gevestig was, as lede van ongereelde vrywilligereenhede die oorlog aan Britse kant meegemaak. Hulle lojaliteit en militêre ondervinding het hulle uiters geskik gemaak om as lede van vrywilligereenhede te dien.

Dat die Transvaalse vrywilligermag binne vyf maande na die beëindiging van die oorlog in Oktober 1902 tot stand gekom het, was die gevolg van die voorwaardes wat aan die groot Imperiale geskenk van perde na die oorlog gekoppel is. Dié perde moes dadelik deur die koloniale owerheid oorgeneem word.

By sy ontstaan was die Transvaal Volunteers uit vyf berede-, drie infanteriekorpse en 'n geniekorps saamgestel. Teen die einde van kroonkoloniebestuur het dit tot 'n goed gedifferensieerde mag ontwikkel. Die Transvaal Volunteers se aandeel in die onderdrukking van die Zoeloe-opstand van 1906 het bewys dat die T.V. teen hierdie tyd 'n goed funksionerende gevegsmag was.

Die oorheersende faktor in die ontwikkeling van die T.V. onder verantwoordelike bestuur was die strewe na interkoloniale militêre samewerking. Hierdie strewe was een van die belangrikste voortvloeisels uit die Zoeloe-opstand van 1906 en het sigbaar vorm begin aanneem in die bepalings van die Johannesburgse interkoloniale verdedigingskonferensie van Januarie 1907.

Interkoloniale samewerking in Suidelike Afrika was onmoontlik sonder eenvormige koloniale verdedigingstelsels. 'n Praktiese patroon vir militêre eenvormigheid dwarsdeur die Britse ryk is op die koloniale konferensie van 1907 in Londen neer- 
gelê. Voortbouend op hierdie patroon is op die Durbanse militêre konferensie van 1908 belangrike aanbevelings ten opsigte van militêre eenvormigheid in die verskillende Britse Suid-Afrikaanse kolonies gedoen.

Die ontwikkeling van die Transvaal Volunteers na 1908 moet gesien word as 'n poging om dié mag, volgens die aanbevelings van die Durbanse konferensie, in ooreenstemming met die verdedigingsorganisasies van die ander Britse Suid-Afrikaanse kolonies te bring. Teen 1912 was hierdie proses voltooi. Reeds voor die totstandkoming van die Unieverdedigingsmag was die verdedigingsorganisasies vir die latere vier provinsies feitlik in alle opsigte eenvormig.

Met die ontstaan van die Unieverdedigingsmag is die volgende aktiewe korpse van die Transvaal Volunteers onder nuwe benamings in die nuwe verdedigingsmag opgeneem: Die Transvaal Horse Artillery, as 8ste Burgerbatterij Transvaal Horse Artillery; die Imperial Light Horse as 4de Mounted Rifles Imperial Light Horse; die Transvaal Scottish as 8ste Infanterie Transvaal Scottish; die Witwatersrand Rifles as 10de Infanterie Witwatersrand Rifles; die Transvaal Cycle and Motor Corps as 11de Infanterie Rand Light Infantry en die Transvaal Medical Corps as die 8ste Veldambulans (Transvaal) Z.A. Mediese Dienst.

Op 30 Junie 1913 is die volgende eenhede van die eertydse Transvaal Volunteers ontbind: Die Northern Mounted Rifles, die Southern Mounted Rifles, die S.A. Railway Engineer Corps, die Transvaal Supply Corps, die Transvaal Veterinary Corps, die Transvaal Intelligence Corps en die Transvaal Transport Corps. Die Transvaal Signalling and Field Telegraph Company is tydelik in die Aktiewe Burgermag opgeneem, maar is met ingang van 1 November 1913 ontbind.

Vanaf sy ontstaan is die kadetorganisasie in Transvaal as deel van die Transvaal Volunteers geadministreer. Die beleid wat teen die einde van verantwoordelike bestuur vir die kadetorganisasie geformuleer is, was die gevolg van 'n lang ontwikkelingsgang en kan kortliks soos volg saamgevat word :

Transvaalse kadette is in skoolkadette en in na-skoolse of senior kadette ingedeel. Skoolkadette is in twee groepe ingedeel, t.w. dié onder veertien jaar wat slegs liggaamlike opleiding ontvang het en dié tussen veertien en agtien jaar wat met gewere uitgerus is. Skoolkadette is in losstaande kompanies ingedeel.

In teenstelling hiermee is senior kadette in een bataljon, genaamd die First Cadet Battalion Witwatersrand Rifles, georganiseer. Hierdie bataljon het hoofsaaklik bestaan uit na-skoolse seuns en jong manne tussen veertien en een-en-twintig wat in die Witwatersrandsegebied woonagtig was.

Gedurende 1909 is voltydse leerlinge, wat ouer as agtien jaar was, en aan skole of kolleges verbind was, ook as senior kadette tot die bataljon toegelaat, al was hulle buite die Witwatersrandsegebied woonagtig. Hierdie kategorie senior kadette is vir opleidingsdoeleindes tot die skoolkadetkompanies toegevoeg.

Wanneer senior kadette die ouderdom van agtien jaar bereik het, moes hulle die eed van getrouheid aflê waarkragtens hulle vir aktiewe diens opgeroep kon word.

Die groot waarde van die kadetorganisasie was dat kadette hulle opleiding sonder onderbreking tot die ouderdom van een-en-twintig jaar kon voortsit. Hierna kon hulle as militêr goedopgeleide en bruikbare lede in vrywilligereenhede opgeneem word.
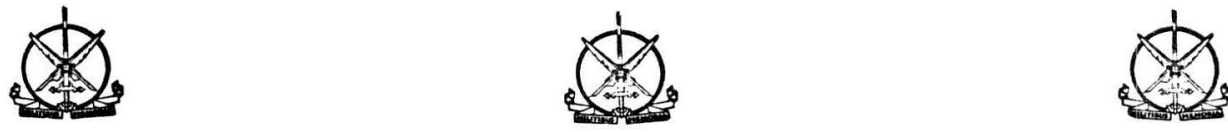


\section{SUMMARY}

\section{THE ORIGIN AND DEVELOPMENT OF THE TRANSVAAL DEFENCE FORCE : "TRANSVAAL VOLUNTEERS" (1900-1912)}

As from June 1899 thousands of Uitlanders started to leave the Witwatersrand area. In the expectation that the approaching war would soon end, most of them settled temporarily in city centres like Cape Town, Kimberley, Pietermaritzburg, Port Elizabeth, East London and Durban.

From here reasonably large numbers joined the British irregular mounted volunteer corps, but the majority remained passive in the respective city centres.

In spite of the fact that the war continued after the occupation of Johannesburg and Pretoria, the British government decided to make a start with the reconstruction of industries on the Rand. For this purpose, military protection was indispensable. Since no troops from the British fighting forces could be set aside to attain this end, the Uitlanders in the city centres were organised into irregular voluntary corps.

This became a reality at the end of November, 1900, with the formation of the Railway Pioneer Regiment and the Rand Rifles, which most Uitlanders joined before the end of the war. In this way they acquired military training and experience.

Financial considerations after the war made it advisable for the British government to reduce the great number of Imperial troops remaining in the Transvaal. In their place Transvaal troops had to be raised, as it was imperative that the colony had, from then on, to rely on its own resources for its defence. There was furthermore no question regarding the fact that the formation of a defence force in the Transvaal after the war was a necessity. Due to a shortage of funds in the colony, however, the only solution was a voluntary system which would allow the government to bear only part of the expenses involved. The military experience of and the loyalty shown by the former Uitlanders on the Witwatersrand, made them ideal to serve as members of such a force.

The formation of this Force - called the Transvaal Volunteers - was made possible in October 1902 when the Imperial government presented the Transvaal government with horses and equipment for 3000 mounted volunteers, as well as equipment for 10000 Transvaal infantrymen.

At its formation the Force consisted of only five mounted and three infantry units. Under Crown Colony government, however, it developed into a well trained defence force. The lion's share it took in the Natal Zulu uprising in 1906 is proof that by that time the Force had also become an effective fighting force.

The Zulu uprising of 1906 was indeed a turning-point in the military development of the British colonies in South Africa as it emphasised the necessity for military co-operation between two or more colonies for mutual defence. Intercolonial military uniformity and co-operation had in fact become indispensable. 
As in other British colonies in South Airica, the development of the Transvaal defence force after 1907, was accordingly aimed at bringing about such military uniformity and co-operation. The lines of conduct to attain this end, were laid down at three conferences, namely the Intercolonial Military Conference (January 1907), the London Colonial Conference (April 1907) and the Durban Military Conference (October 1908).

This means that even before the establishment of the Union Defence Force, the defence organisations of the four provinces were almost uniform in all respects, furthermore, that as a result of the development of the Force after 1907, the Transvaal Volunteers could more easily be merged into larger organisations of the Union Defence Force when this was required after the formation of the Union of South Africa in 1910.

\section{LITERATUUR EN BRONNELYS:}

\section{LITERATUUR.}

(a) Boeke.

Beirne, L. J. (red.): Johannesburg Royal Presentation Johannesburg: Its Municipality, Art, Endeavours, Associations, Clubs, Communities, Institutions, Public Bodies, Regiments and Societies, The Transvaal Leader, Johannesburg, sonder datum.

Boswan, W.: The Natal Rebellion of 1907, Cape Town, 1907.

Chatham Royal Engineer Institute (red.): Detailed History of the Railways in The South African War 1899-1902, vol. I, Letterpress, W. \& J. Mackay \& Co. Ltd., Chatham, 1904.

Headlam, C. (red.): The Milner Papers South Africa 1899-1905, vol. II, Cassell \& Co. Ltd., London, 1933.

Juta, H. C.: The History of the Transvaal Scottish, Hortors Ltd., Johannesburg, 1933.

Muller, C. F. J. (red.): 500 Jaar Suid-Afrikaanse Geskiedenis, Academica, Pretoria, 1968.

Newton, A. P.: Select documents relating to the unification of South Africa, vol. II, London, 1924.

Roos, J. C.: Johannesburg en die Tweede Vryheidsoorlog Oktober 1899-Mei 1900, ongepubliseerde D. Litt.-proefskrif, U.K.O.V.S., 1949.

Stirling, J.: The Colonials in South Africa 1899-1902, William Blackwood and Sons, Edinburgh and London, 1907.

Stuart, J.: A History of the Zulu Rebellion 1906 and of Dinuzulu's arrest, trial and expatriation, Macmillan and Co. Ltd., London, 1913.

Williamson, J. A.: A Short History of British Expansion - The modern Empire and Commonwealth, deel II, Macmillan and Company Limited, London, herdruk 1965.

(b) Koerante.

Cape Times, Junie 1900-Junie 1902.

The Johannesburg Gazette, Des. 1900.

The Star, Junie-Oktober 1902, April-Aug. 1906.

(c) Tydskrifte.

Militaria, Tydskrifte vir Militêre Geskiedenis, 1 (3), 1969.

Militaria, Tydskrifte vir Militêre Geskiedenis, 1 (5), 1969.

\section{ARGIVALE BRONNE.}

(a) Gedrukte.

(i) Transvaalkolonie amptelike publikasies.

\section{UITVOERENDE RAAD}

1901. Executive Council Transvaal. Minutes from 4th April to 25th September 1901.

1901. Executive Council Transvaal. Minutes from 8 October 1901 to 19th June 1902.

1902. Executive Council Transvaal. Minutes from 21st June 1902 to 31st December 1902, vol. I.

1905. The Transvaal Minutes of Meetings of the Executive Council. January to June 1905 . 
1906. The Transvaal Minutes of Meetings of the Executive Council. January to June (E.C.R. 1-1197), 1906.

1906. The Transvaal Minutes of Meetings of the Executive Council, July-December (E.C.R. 1198 - 2451), 1906.

WETGEWENDE VERGADERING, 1907-1910.

1907. Debates of the First Session of the Legislative Assembly of the Transvaal 1907. Comprising the period March 21st-August 20th.

1907. Transvaal Annexures to the Votes and Proceedings of the Legislative Assembly, vol. I, 1907.

1908. Debatten van de Twede Zitting van de Wetgewende Vergadering van de Transvaal. 1908. Plaatsgevonden gedurende het tijdperk: 15 Junie-22 Augustus.

1909. Debatten van de Derde Zitting van de Wetgewende Vergadering van de Transvaal 1909. Plaatsgevonden gedurende het tijdperk 1 Junie-7 Julie.

1910. Transvaal Annexures to the Votes and Proceedings of the Legislative Assembly, vol. 2, 1910.

\section{GOEWERMENTSKOERANTE.}

\section{Transvaal Government Gazette.}

1902. Vol. v, nos. 138, 144, 159, 160, 166.

1903. Vol. vi, nos. 173, 197 en vol. vii, nos. $214,210$.

1904. Vol. viii, nos. 238, 248, 250. Vol. x, nos. 281, 285. Vol. xi, nos. 297, 299, 301.

1905. Vol. viii, no. 330. Vol. xii, nos. 305, 306, 312. Vol. xiii, no. 332. Vol. xiv, no. 349.

1906. Vol. xvi, nos. 371, 376. Vol. xvii, nos. 383, 394. Vol. xviii, nos. 398, 404.

1907. Vol. xxii, nos. 471, 486. Vol. xxiii, nos. 497, 498.

1908. Vol. xxiv, no. 506. Vol. xxv, no. 533. Vol. xxvi, nos. 541, 546, 599, 565. Vol. xxvii, nos. 572, 577.

1909. Vol. xxviii, no. 592. Vol. xxx, no. 631.

1910. Vol. xxxii, nos. $650,659$.

\section{BLOUBOEKE.}

1903. Transvaal Administration Reports for 1903. Part II. Administration.

1904. Transvaal Administration Reports for 1904. Part II. Administration.

1905/1906. Transvaal Administration Reports for the year 1905/1906. Part II. Colonial Secretary's Department.

1906. Minutes of Evidence (With Appendices) of the Transvaal Volunteers Commission.

1906. Reports of the Transvaal Volunteers Comission, February 1906.

ST AATSDIENSLYSTE.

1906. Civil Service List 1906.

1909. Transvaal Public Service List 1909.

(ii) Sentrale regering amptelike publikasies.

GOEWERMENTSKOERANTE.

1912. Union of South Africa Government Gazette, vol. ix, no. 255, 1912.

\section{BLOUBOEKE.}

1913. U.G. 61/1913. Union of South Africa. Annual Reports. Department of Defence and Executive Commands for year ending 30th June 1913.

(iii) Britse amptelike publikasies.

WITSKRIFTE.

1899-1902. South African War 1899-1902. Confidential telegrams 12th October 1899 to 1st October 1902.

1900. South Africa. Vol. v. Telegrams and Letters sent by Field-Marshal lord Roberts, K.P., G.C.B., V.C., \& c., \& c., From 14th September to 31st October, 1900.

1900. South Africa, vol. vi. Telegrams and Letters sent by Field-Marshal lord Roberts, K.P. G.C.B., V.C., \& c. Ist November to 26th December, 1900.

1900. Journal of the Principal Events connected with South Africa - Part 7. From 1st November to 31st December 1900.

1901. Journal of the Principal Events connected with South Africa. Part 8. From 1st January to 28th February, 1901. 
1902. Journal of the Principal Events connected with South Africa. Part 16. From 1st May to 31st May, 1902.

\section{IMPERIALE BLOUBOEKE.}

1906. C.d. 3027: Natal. Further correspondence relating to native disturbances in Natal. 1906. C.d. 3247. Natal. Further correspondence relating to Native disturbances in Natal.

(b) Argiefgroepe in Transvaalse Argiefbewaarplek.

(i) Argief van die Private Secretary to the Governor Transvaal and Orange River Colony (1901-1910).

1901-1905. P.S. 323: Volunteer Forces in Transvaal. 1901-1905. P.S. 328: Volunteer Forces in Transvaal. 1906. P.S. 68/4/1906: Guns - Transvaal Volunteers. 1907. P.S. 68/1/1907: Defence. Inter-Colonial.

1907. P.S. 68/9/1907: Volunteers. Guns.

1907. P.S. 68/16/1907: Volunteers. Reorganisation of.

1908. P.S. 68/3/1908: Volunteers - Reorganisation of - General File.

1908. P.S. 82/25/1908: Military Conference on South African Forces, Durban 1908.

1909. P.S. 68/5/1909: Volunteers. Reorganisation of - General File.

(ii) Argief van die Transvaalse Koloniale Sekretaris.

1907. P. M. Band 75: Colonial Conference 1907. Agenda Papers.

1908. P.M. Band 62: Inter-Colonial Conference 1908, Jan. 8-1908 May.

(iii) Argief van die Clerk to the Legislative Council 1902-1907.

1902. 90/24/1902: Volunteer Corps Ordinance no. 33 of 1902.

(iv) Argief van die Clerk to the Executive Council 1907-1910.

1907. Original minutes 1-1155, 1907. March-Nov.

1908. Original minutes 1156-1320. 1907, Dec. 1-1128. 1908, Jan.-Sept.

(v) Argief van die Colonial Secretary Transvaal (1901-1910).

1901. C.S. 1424: Arrangements for taking over the various Departments which either still are, or have been, under the Military Governor of Johannesburg.

1901. C.S. 7227: Stationery for the Rand Rifles.

1902. C.S. 2425: Rand Rifles.

1902. C.S. 3801: Volunteer Corps in Pretoria - re members of the civil service joining above.

1902. C.S. 5042: Pretoria Volunteer Guard. Requesting expression of opinion as to whether the existence of above corps is approved by the Administrator \& whether it is likely to be continued when a Volunteer Act comes into Force.

1902. C.S. 8530: Rifle Club at Standerton.

1902. C.S. 8999: Pretoria Volunteer Guard. Submitting suggestions for consideration re above.

1902. C.S. 13378: Arms and Ammunition Ordinance 1902 - Rifle Association of Transvaal.

1902. C.S. 14676: Transvaal Volunteers.

1903. C.S. 2979: Prohibition of the importation of Arms into the Transvaal.

1904. C.S. 39: Transvaal Volunteers.

1905. C.S. 1033: Report on provision of equipment of Volunteer Forces in the Transvaal.

1905. C.S. 2182: Volunteer Returns. Strength and Distribution.

1905. C.S. 5468: Financial State Transvaal Cadets.

1905-1909. C.S. 7115. Appointment of Major Lamont as Chief Staff Officer of the Transvaal Volunteers. (Band no. C.S. 1027).

1905-1909. C.S. 4443: Transvaal Cadet Corps. C.S. band no. 1028).

1907. C.S. 9989: Resolutions of Inter Colonial Defence Conference.

(c) Fotokopiee in Transvaalse Argiefbewaarplek.

(i) Colonial Office (1896-1902).

F.K. 351. Lêer no. 37501: Return of Refugees \&c. to Transvaal.

F.K. 351. Lêer no. 38596: Return of Refugees to Transvaal.

F.K. 352. Lêer no. 39335: Return of Refugees to Transvaal \& Formation of Irregular Volunteer Force for Defence of Rand.

F.K. 353. Lêer no. 40185: Return of Refugees to Transvaal

F.K. 355. Lêer no. 41874: Refugees from Transvaal. 
F.K. 355. Lêer no. 41950: Return of Refugees to Transvaal.

F.K. 405. Lëer no. 8683: Refugees per Canada left Cape Town 15 March: Expected to arrive at Southampton 2 April.

F.K. 899: Lêeer no. 2358: Destruction of Property by Boers at Kleinfontein.

F.K. 889. Lêer no. 3289: Destruction of Mine Property by Boers. Proposed formation of Mine Guards.

F.K. 889. Lêer no. 4324: Destruction of Mine Property. Formation of Mine Guards.

F.K. 890. Lêer no. 5247: Destruction of Mining Property by Boers. Formation of Town Guards.

F.K. 890. Lêer no. 5900: Destruction of Mining Property by Boers. Formation of Mine Guard.

F.K. 909. Lëer no. 45780: Return of Refugees.

F.K. 943. Lêer no. 4605: Return of Refugees.

F.K. 958. Lêer no. 31922: Rand Rifles - Disability Pensions.

F.K. 978. Lêer no. 43103: Appt. of Asst. Adjt. Genl. of Transvaal Volunteers.

F.K. 1006. Lêer no. 3379: Rand Rifles and Future of Local Forces - Organisation \& Control.

(ii) Milner Papers.

F.K. 56/1145 en F.K. 116/1205.

(iii) Kitchener Letters.

F.K. 1621 (vol. 1). en F.K. 1622 (vol. 2).

(d) Versamelings.

Lord Roberts Papers (Manuscripts).

(Operations. Reports and Operations. Telegrams received by lord Roberts from Generals and others in South Africa, 1899-1900).

1906. Vol. 63, waarin: Telegrams received from High Commissioner October 1900. 


\section{ANNUAL REPORT ON THE TRANSVAAL VOLUNTEERS AND CADETS FOR THE YEAR 1910-1911*}

* Bogenoemde verslag, wat nie 'n deel van die M.A.-verhandeling vorm nie, is bygevoeg ten einde die leser 'n indruk te gee van 'n jaar se bedrywighede van die Transvaal Volunteers en Kadette.

- Die redaksie.

* The abovementioned report, which does not form part of the thesis, is inserted to give the reader an idea of the yearly activities of the Transvaal Volunteers and Cadets. 


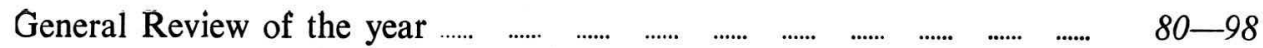

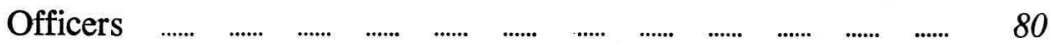

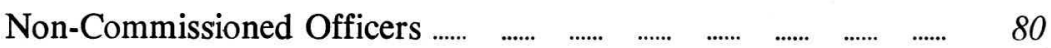

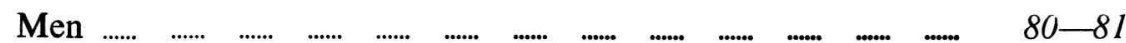

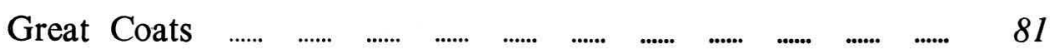

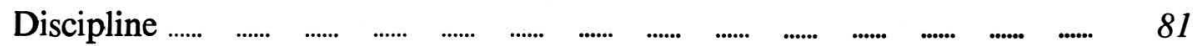

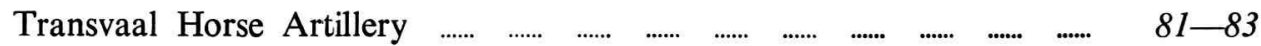

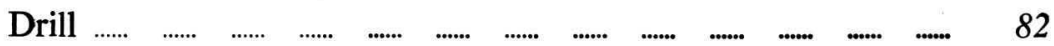

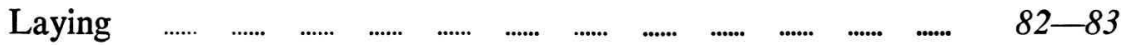

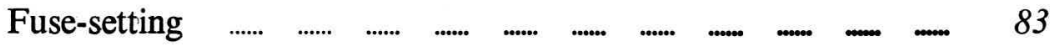

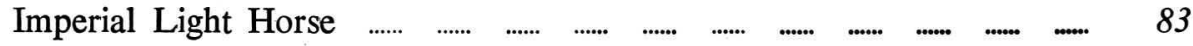

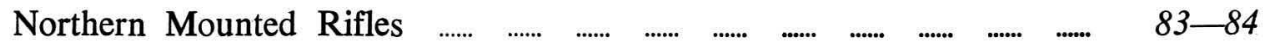

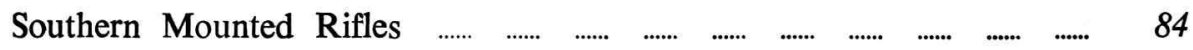

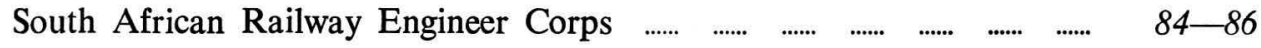

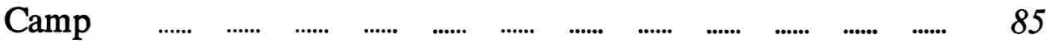

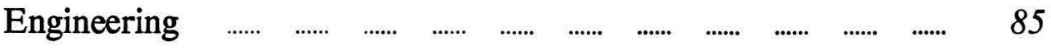

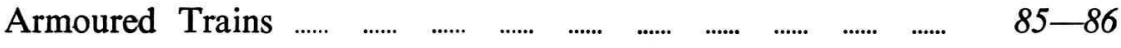

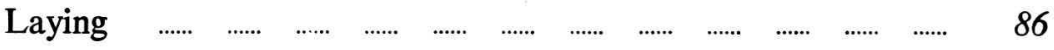

$\begin{array}{lllllllllllll}\text { Fuse-setting } & \ldots \ldots . . & \ldots \ldots . . & \ldots \ldots . & \ldots \ldots . & \ldots \ldots . & \ldots \ldots . & \ldots \ldots . & \ldots \ldots . & \ldots \ldots . & \ldots \ldots . & \ldots \ldots . & 86\end{array}$

$\begin{array}{lllllllllllll}\text { Searchlights } & \ldots \ldots & \ldots \ldots & \ldots \ldots . & \ldots \ldots & \ldots \ldots & \ldots \ldots & \ldots \ldots . & \ldots \ldots & \ldots \ldots & \ldots \ldots & \ldots \ldots . & 86\end{array}$

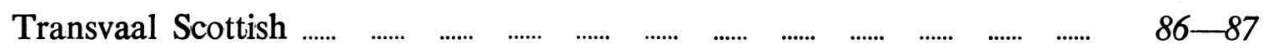

$\begin{array}{lllllllllllll}\text { Witwatersrand Rifles } & \ldots . . . & \ldots . . . & \ldots . . . & \ldots . . . & \ldots . . . & \ldots . . . & \ldots . . . & \ldots . . . & \ldots . . . & \ldots . . . & \ldots . . . & 87\end{array}$

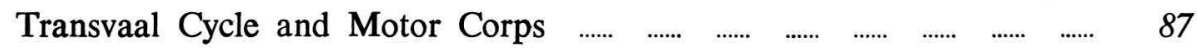

Transvaal Signalling and Field Telegraph Company .......

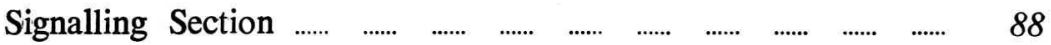

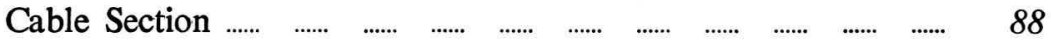

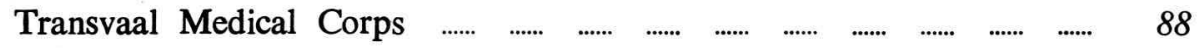

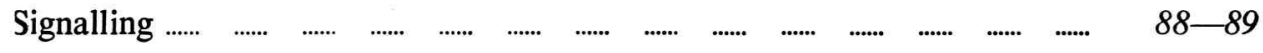

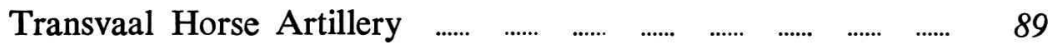

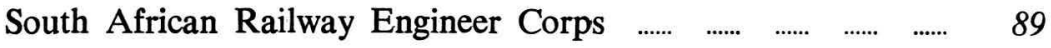

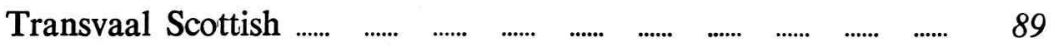

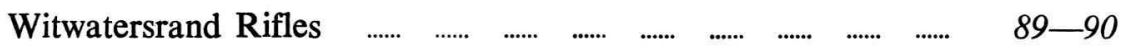

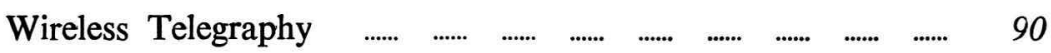

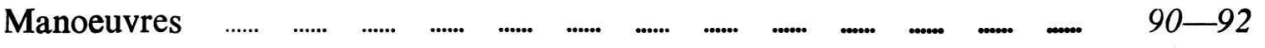

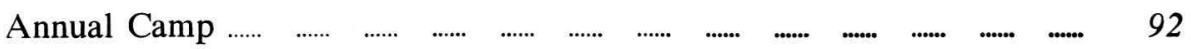




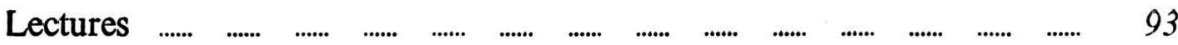

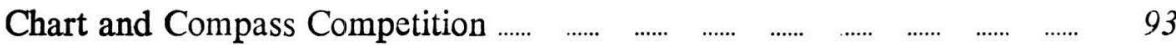

Long Distance Marching and Shooting Competition …........................ $\quad$.... 93

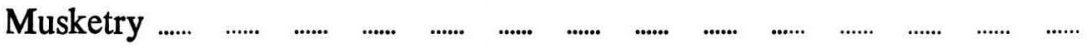

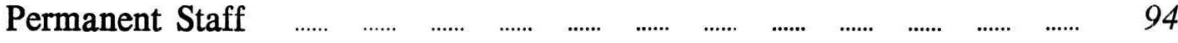

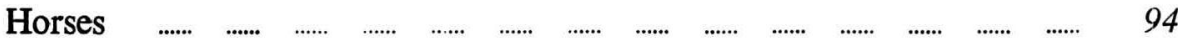

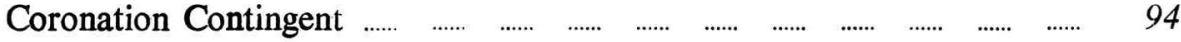

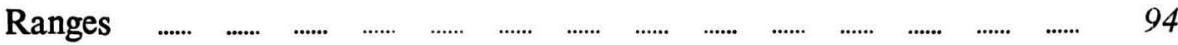

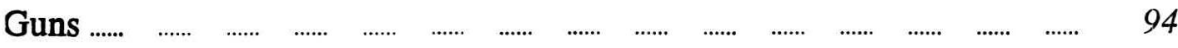

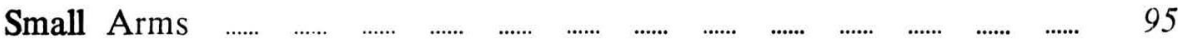

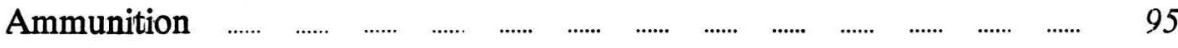

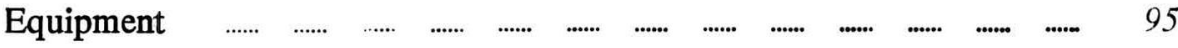

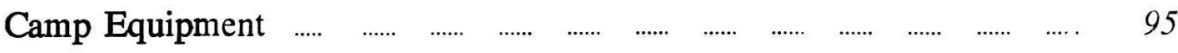

$\begin{array}{llllllllllllllll}\text { Uniform } & \ldots \ldots . . & \ldots \ldots . & \ldots \ldots . & \ldots \ldots & \ldots \ldots . & \ldots \ldots . & \ldots \ldots . & \ldots \ldots . & \ldots \ldots . & \ldots \ldots & \ldots \ldots & \ldots \ldots & \ldots \ldots & \ldots \ldots . & 95\end{array}$

$\begin{array}{llllllllllllllll}\text { Saddlery } & \ldots \ldots & \ldots \ldots & \ldots \ldots . & \ldots \ldots . & \ldots \ldots . & \ldots \ldots . & \ldots \ldots . & \ldots \ldots & \ldots \ldots & \ldots \ldots & \ldots \ldots & \ldots \ldots & \ldots \ldots & \ldots \ldots . & 95\end{array}$

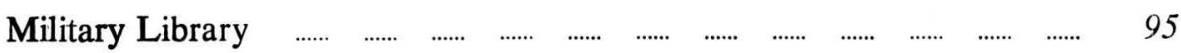

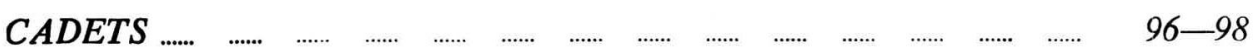

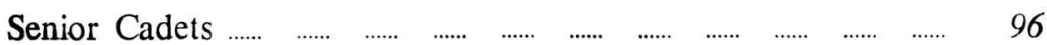

School Cadets …..........................................................

$\begin{array}{llllllllllll}\text { Strength } & \ldots \ldots & \ldots \ldots \ldots & \ldots \ldots . & \ldots \ldots . & \ldots \ldots . & \ldots \ldots . & \ldots \ldots & \ldots \ldots . & \ldots \ldots . & \ldots \ldots . & 96\end{array}$

$\begin{array}{llllllllllll}\text { Efficiency } & \ldots \ldots . & \ldots \ldots & \ldots \ldots . & \ldots \ldots & \ldots \ldots & \ldots \ldots & \ldots \ldots \ldots & \ldots \ldots & \ldots \ldots & \ldots \ldots . & 96-97\end{array}$

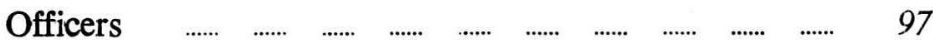

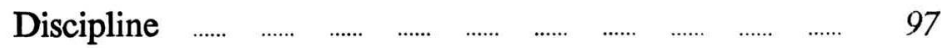

$\begin{array}{llllllllllll}\text { Musketry } & \ldots \ldots . . & \ldots \ldots . . & \ldots . . . & \ldots \ldots . & \ldots . . . & \ldots . . . & \ldots . . . & \ldots . . . & \ldots . . . & \ldots . . . & 97\end{array}$

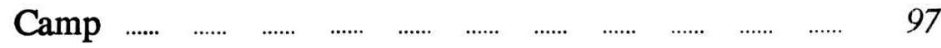

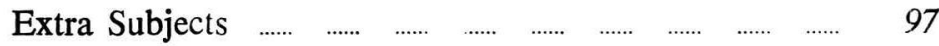

New Companies .................................................

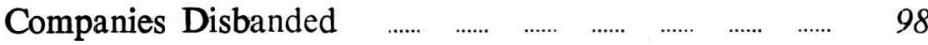

\section{APPENDICES}

Appendix A. Comparative Statement of Establishment, Strength, and Efficiency, 1909-10 and 1910-11 ..................... 98

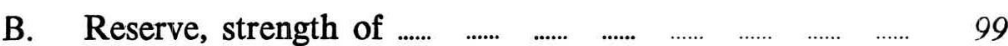

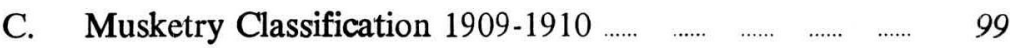

D. Musketry Classification 1910-1911 ..........................

E. Efficiency requirements, 1910-1911 ............................ 100

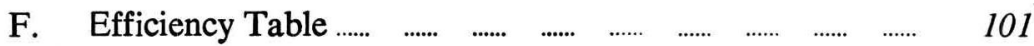




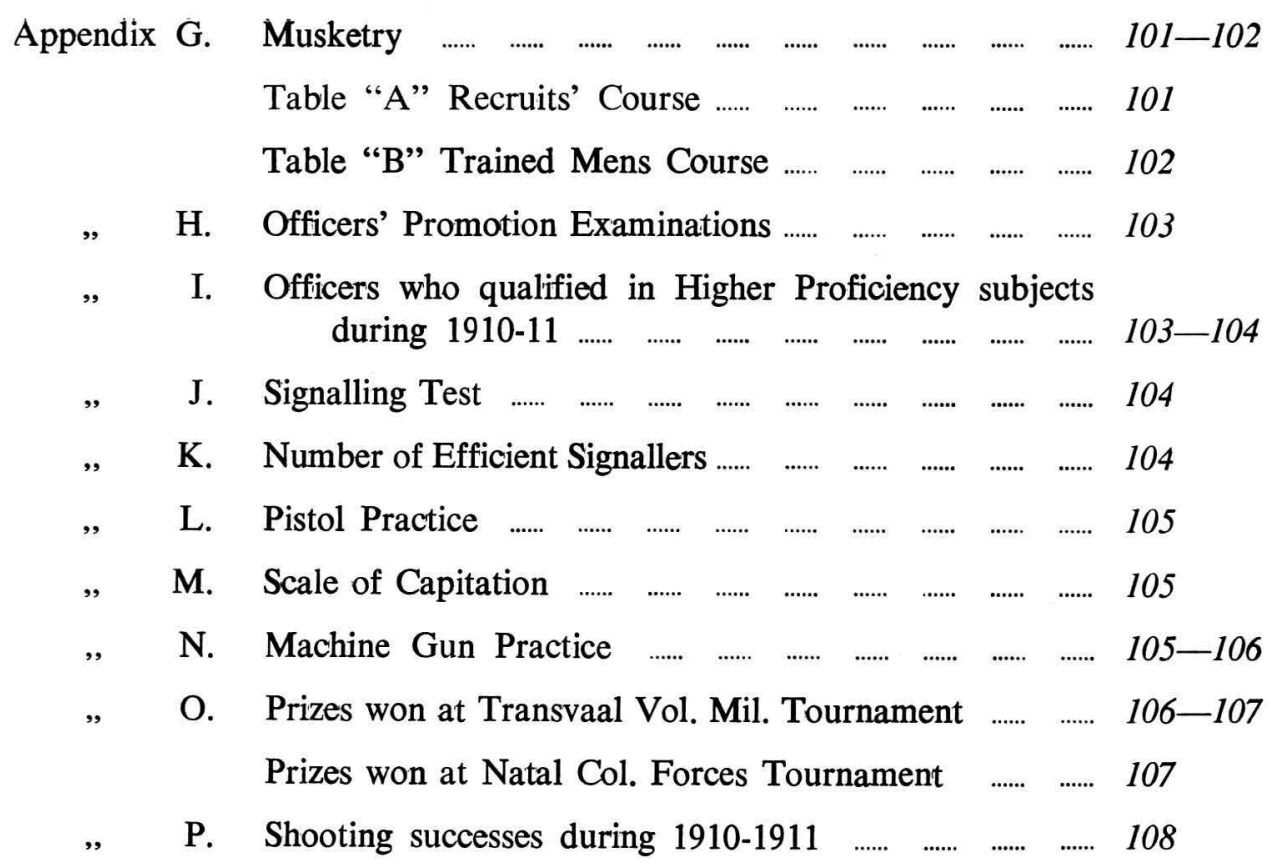




\section{VOLUNTEERS. General Review of the Year.}

It is satisfactory to be able to report that the efficiency of the Force has been generally maintained and in some cases augmented.

There has throughout the year been loyal support by all ranks, and I have no hesitation in saying that the spirit and enthusiasm prevailing are greater now than ever. More work has been done this year than formerly, and an increased amount of "Ceremonial Parade" was occasioned by the visit of H.R.H. the Duke of Connaught. The Review by His Royal Highness saw the whole Force at its best, and in that direction it was the steadiest piece of work the Volunteers and Cadets have done up to date.

\section{OFFICERS.}

So much of the efficiency attained depends on the class of Officers we have, the amount of interest they display and knowledge they possess of Military matters generally, that no opportunity is lost of impressing on them the extreme importance of being thoroughly competent in all branches of their studies, and of being upto-date in everything. In one or two Corps keenness prevails with all the Officers, and that example might well be emulated. In most units, however, the position is that, whilst all Officers do the necessary amount of work to become efficient themselves and get their men efficient, it is to the energetic and enthusiastic few that one looks to put the finishing touches and extra value into a Corps. This is not sound, and Commanding Officers are constantly advised to replace the least keen Officers, or those whose civil work prevents them from giving a good deal of time and labour to the cause, by gentlemen who are prepared to sacrifice themselves and are in a position to devote the necessary amount of time to the study of Military matters. Commanding Officers have co-operated, and as a result we have undoubtedly a keener and more useful body of Officers to-day than formerly, and I believe that by closely watching this important matter we may confidently look to see their efficiency and utility increase as the years go on.

\section{NON-COMMISSIONED OFFICERS.}

In many Corps the Non-Commissioned Officers are very junior and are in consequence somewhat inexperienced. Their training to a higher level is most desirable, and I see no way of effecting this except by an increase in the Staff of Instructors. The standard of Military knowledge attained by Non-Commissioned Officers depends almost entirely on the amount of time that Instructors can give them, and at present that does not amount to very much.

$M E N$.

There has been no falling off in the material comprising the Force, and the physique is excellent, which fact will reduce the number of rejections for service at the last minute should the Volunteers be called out. Commanding Officers have no trouble in recruiting, amongst the keen and intelligent, who will introduce common sense into their work. As formerly, individuality and intelligent thinking are encouraged, for the fostering of these traits gives all ranks a greater interest in the work, whilst they actually increase the fighting value of the machine. Most units are now in the strong position of being able to select their men, as the annual wastage does not come up to the number of young men wishing to join. 
It should be mentioned that in several regiments training goes on which fits the members for something more than that actually required by the branch of the Service they happen to be serving in. As instances: the Transvaal Horse Artillery this year won both First and Second Prize in the Chart and Compass Competition, which one must consider a competition clearly favouring the purely mounted men. It is a fair inference, therefore, that, should occasion make it necessary, the Transvaal Horse Artillery, after very little instruction, could take the field as Mounted Rifles. The South African Railway Engineer Corps, in spite of their heavy programme of Engineering work, find time to train and manoeuvre as Infantry, in which capacity they might be required to serve. The Transvaal Medical Corps receive instruction in Musketry and show themselves very efficient shots, and would thus be able to protect themselves and those they were tending, would events make it necessary by reason of an Enemy being uncivilized and not recognising the Geneva Cross. Amongst the Engineers, Infantry, and Cyclists is to be found a very large number of men who can ride well and in them the Country has a dependable body of disciplined men easily turned into Mounted Rifles on emergency. The type of recruit joining the District Corps has improved, and this particularly holds good concerning the far North.

\section{GREAT COATS.}

The lack of Great Coats amongst the force still constitutes a serious blemish. On the present grant Corps are not in a position to spend money in that direction, it would too seriously interfere with that spent on training. Should the force be called out into the field for service only some 500 could go with Great Coats, and it would be impossible to obtain hurriedly a suitable article in any numbers with which to clothe the men. The matter is a very serious one, and I consider provision should be made either by storing a large number of coats at the Ordnance Store, purchased out of money specially voted, or else by granting Corps extra money for the sole purpose of purchasing this clothing.

\section{DISCIPLINE}

A good state of discipline has been maintained. Anything in the nature of Military crime has been non-existent; the few offences have been of an almost trivial nature.

Commanding Officers realise the necessity of maintaining as high a state of discipline as possible, and irregularities of any sort are looked into without delay. The confidence inspired in the rank and file by the increased knowledge and greater thoroughness of the Officers helps enormously in this direction, and it is perfectly apparent that the maintenance of discipline grows easier each year as the men feel this confidence growing, a confidence due to the fact that the Officers endeavour to keep themselves up to date and thus become more reliable in their Military duties.

\section{TRANSVAAL HORSE ARTILLERY}

The Brigade has done excellent work throughout the year. Both Battery and Section Commanders have shown a decided advance in the qualities required to command and shoot Guns. They have more confidence and decision and are more competent to grasp a situation and deal with it quickly and effectively. Rules of ranging were not always observed, and observation in many cases is faulty, but this will only come with constant practice. The picking-up and pointing out of targets needs improvement. All Officers set an excellent example and, in view of the limited opportunities for learning their work, they attain a high standard of efficiency. 
The Non-Commissioned Officers have improved steadily, though slowly, in knowledge of gunnery and fire discipline, and support their Officers well. The remarks as to picking-up and pointing out targets apply here also. Some of the Sergeants have shown themselves capable of taking a Section Commander's place temporarily and all, I think have gained confidence. In some cases the Nos. 1 need to take a firmer grip of their sub-section on manoeuvre and in action.

The men as a whole are keener than ever, and the few who are less enthusiastic are gradually being dropped. There is now a larger proportion of men with several years Artillery experience than ever before. Speaking generally, they have done well both in number of drills put in, turn-out, and increased knowledge of their guns and its working.

Riding is much the same as last year. Whilst not their strongest point, it is very fair and is as good as one is likely to get with urban volunteers. They have their hearts in the right place, and considering the class of animal ridden, they do fairly well.

The work at manoeuvre has improved but is apt to be ragged at times, especially in the detachments. Untrained horses account for much of this. Intervals and distances still require attention, and the attainment of pace is to be deprecated except as secondary to steadiness and correctness.

The following is an extract from the report by Captain Rochfort-Boyd, Royal Horse Artillery, who watched them very carefully during the Easter Camp :-

"Having attended the Easter Practice Camp of the Transvaal Horse Artillery as "Umpire, I have the honour to report as follows for your information :-

"First, I desire again to congratulate the Brigade on the very high state of efficiency "in which I found them.

"I reported last year that I considered they attained a very high standard, and I "am of the opinion that they have distinctly raised that standard this year. This "must have entailed a lot of spade work throughout the year, and I certainly saw in "Camp an enthusiasm in their work that I think calls for the highest praise.

"A convincingly higher standard of shooting was reached."

A point reflecting great credit on the Brigade is the fact that, entering three Teams, they got First and Second in the Chart and Compass Competition, which is work in a direction not usually undertaken by Gunners.

\section{DRILL.}

The drill is good and quiet on the whole, especially " $B$ " Battery. " $A$ " Battery have a larger proportion of recruits, which may account for their slight inferiority in this respect. The drill is still slow but considering how short-handed they usually are, one must expect this.

\section{LAYING.}

The Layers have a better grip of the business and are more reliable than formerly. One must attribute this to the fact that certain men are now selected as Layers in the year and are trained as a special class. There are many difficulties in the way of this but on the whole it has proved better than the former system. In " $\mathrm{B}$ " 
Battery most of the credit of the improved laying is due to Captain Collender, who has put in a great deal of time and work in this direction. There is much to be learnt yet, of course, in both Batteries.

FUSE SETTING.

There is an improvement in fuse-setting. At practice some series show the "setting" to have been regular, in others the opposite. " $B$ " Battery's fuses were old, but it is a sound principle to blame the Setters rather than the fuses. The impossibility of getting the same men "setting" always with Volunteers militates against good fuse-setting, and naturally the excitement of practice accounts for much. Fusesetting is a wearisome parade and some sub-sections are much better than others in getting their men out for it, but I think there is less cause for fault finding in this direction than before.

\section{IMPERIAL LIGHT HORSE}

The stamp of man and physique of former years has been maintained and their numbers on parade have usually been good. Their turn-out has, in appearance, usually been fair but there is room for improvement in this important matter, which requires more attention on the part of Squadron and Troop Officers. In addition, more attention should be given to steadiness generally. Lack of confidence on the part of some Officers is responsible for this, coupled with a tendency to leave too much to Squadron Sergeant Majors, and a greater control and exercise of command by Subordinate Officers and by the Non-Commissioned ranks is necessary.

Signalling is entirely neglected, and this militates against the Corps fighting value. I feel this situation can be remedied if proper interest be taken.

The best work of the Corps is undoubtedly in the field, for the horses are good and the men are usually good riders and look after their animals. They move very quickly and work with a good deal of intelligence. Unneccessary waits in the saddle are not uncommon, and one or two Squadrons still think they can gallop into or across any fire that may be opposed to them. Whilst it is always sound to encourage rapidity of movement when it is economically used, it was obvious sometimes that pace was made everything, and the belief seemed to prevail that galloping horsemen were quite irresistable. Against fairly well-posted opponents this is a great fallacy.

\section{NORTHERN MOUNTED RIFLES}

Men and horses of this Corps are pretty much the same as last year, and what improvement is shown is due to a keener spirit displayed by the Officers generally. The numbers were always good, except in the case of one Troop, which is being disbanded. The rank and file are fair shots and long distance riders, with a good eye for country. They are well conducted and keen, and anxious to carry out their duties to the best of their ability. Many have to ride as much as 60 to 80 miles to a Concentration. The turn-out, whilst it is good in the more Southerly squadrons, lacks something in the squadrons placed in the North, even after allowing for the fact that great care had to be excercised in the issue of kit owing to financial reasons.

The horses were better than last year, particularly in the North, where they have been much handicapped by virulent horse-sickness in former years. The experiment with mules was dropped at the beginning of the year as it proved unsatisfactory, and all are now mounted on hard, useful, sure-footed Cobs. The men can stand 
any amount of work and hardship, but are not good horse-masters, and Squadron and Troop Officers will have to work hard to get this most important matter better understood by the rank and file.

\section{RESERVES.}

The Corps has a large reserve of men, chiefly residing in the North, formed into Troops under their own Leaders. An inspection of several of these Troops goes to show that great care will have to be excercised in the selection of Officers and men. One or two Troops were very good indeed, and the rifles were well cared for. Unfortunately in the majority of cases there was very little control and the rifles were badly looked after. There will probably be a considerable amount of sorting out during the coming year.

\section{SOUTHERN MOUNTED RIFLES}

This regiment has had a very successful year and finished up well at the final Concentration at Florida, where they had 534 in Camp out of a total strength of 591, which, in view of the enormous area from which they are recruited, is most satisfactory. Many had to come as much as $\mathbf{3 0 0}$ miles by rail and had previously to trek from 40 to 50 , and occasionally as much as 90 miles, to the nearest Railway Station.

The cost of the Concentrations, which are of the greatest value and importance, falls very heavily on the two District Corps, the Northern and Southern Mounted Rifles, and I feel strongly that extra provision should be made for these two Corps to meet the extra expense, in the form of an increased Capitation Allowance, to be granted only if the whole Corps concentrates at one camp.

They are a hard, wiry lot of men insured to hardship; mounted on the useful Cob of the Country which, though without great pace, can cover very great distances without undue fatigue. They are Commanded by a lot of keen Officers, who are kept well up to the mark by their Commanding Officer. The turn-out often leaves something to be desired, but in Camp there came a marked improvement as soon as it was possible to have several consecutive days of inspection. Their drill is steady and quiet but their best work comes when operations start in the field. There one finds a good deal of common sense and subtlety in their way of looking at and carrying out their work. Long distances do not alarm them, and as they are hard and fit they thrive on manoeuvres.

\section{RESERVES.}

Reserves in this District have not enrolled as freely as one would wish, due probably to a large number of rifle clubs which are being systematically organised, especially throughout the South-Eastern Transvaal.

\section{SOUTH AFRICAN RAILWAY ENGINEERS CORPS}

Composed of Railway Employees, amongst whom is a large number of mechanics and engineers, the Corps has in its ranks plenty of capacity and judgment, so necessary in a Volunteer Corps of Engineers, where the work is often of a difficult and sometimes technical character, requiring intelligence above the average.

I have found consistently throughout the year a great improvement in turn-out, a fault that has been eliminated by the constant supervision of the Officers. 
There is little time to spare for drill and ceremony as practicaliy all the hours of work are devoted to Engineering which is as it should be; but I am glad to be able to report that this year their drill also shows a considerable improvement, as they are very steady and quiet. The Officers of the Corps have come out with the high average of 109.3 in revolver practice, thus heading the list of units, exclusive of the Transvaal Horse Artillery who fire a different course.

In the field when acting as Infantry, in which direction they are still trained, they are always reliable. It is naturally very difficult to get them away from their Railway duties in very large numbers at any one particular time, and consequently they do not get much practice for co-operation with other troops. They turned out in good numbers for the Easter Manoeuvre, acting as Infantry, but were not called up for the General Easter Camp as it was deemed advisable to collect them later in the year at a Special Camp confined entirely to their own particular work.

\section{CAMP.}

This Camp was most successful, and Engineering work of a difficult nature was indulged in. A large redoubt was built in which every form of revetment was shown, head-cover, traverses, loop-holes, rifle rests, field kitchen, etc., whilst outside obstacles, such as wire entanglements and abattis with fire alarms and fougasses, were constructed. The best piece of work was a trestle bridge which eclipsed anything in the bridging line they had previously undertaken. It had a road-way of nearly 90 feet, was strong enough to carry light wagons, and was built over a river with a very rugged bed, necessitating a good deal of ingenuity as regards the construction and placing of the trestles. Various hasty demolitions were also carried out, and practical demonstrations of nearly the whole of the subjects in the Manual of Military Engineering were given.

The Electricians provided electric light throughout the camp, the connections being brought from the Armoured Trains and the installation proving entirely satisfactory. This Corps won the Signalling Shield. There are 10 efficient signallers and 7 undergoing instruction.

In addition, a great interest is taken in Bayonet Fighting, and many prizes have been taken by the Regiment at the various Tournaments.

They have the extra expense of keeping up a certain amount of technical equipment and of purchasing new equipment in order to be up to date; I think that these liabilities should be met from a special grant as the Corps is scattered and its administration in consequence somewhat expensive.

\section{ARMOURED TRAINS.}

Three trucks are armed with 12 pr. Q.F. (12 cwt) Guns, and are stationed at Pretoria, Johannesburg and Germiston.

Of the Officers two had given up command of the Guns the previous year and only took charge again late in the season when it was found that no other Officers were available. Considering the handicaps they laboured under, they did well. The third Officer was new to the Gun, this being the first year he has commanded it, or had any Artillery experience. I therefore did not expect much from him at practice but think his first attempt was creditable.

Amongst the Non-Commissioned Officers is some excellent and keen material who do their best to work up their guns. There are too many Non-Commissioned Officers in the gun teams, but this seems unavoidable. 
The supply of men is so intermittent and irregular that it is difficult to attain and retain a high standard of drill, but the class of man being intelligent, a fair state of efficiency obtains.

\section{LAYING.}

Laying has been good in two guns, in one of which there were old Layers, and in the other new men. Indifferent in the third, where the Sergeant himself laid the gun during a part of practice owing to not being able to trust his Layer, a new man. A great deal more practice is required in this important work.

\section{FUSE-SETTING.}

Fuse-setting could be a good deal better. The fuses are old but on more than one occasion they were found to have been wrongly set. More instruction and practice is neccessary.

\section{SEARCHLIGHTS.}

Each Armoured Train is fitted with a Dynamo which should run two Searchlights. These Dynamos should generate a current of 5 Kilowats, which is required with a minimum of safety to supply the two Projectors of 13" diameter, but, having been very much used, the most that can now be got out of them is $1 \frac{1}{2}$ Kilowats, which is hardly sufficient to run one searchlight for each Train.

The one great drawback with the system of running these searchlights is that they are entirely dependent upon the train engine for the supply of energy to run them as they are steam-fed, and if the engine is detached for watering or other purposes the lights are at a standstill until its return. The Electricians of the Railway are of opinion that each Dynamo truck should be fitted with a petrol engine capable of generating from $7 \frac{1}{2}$ to 10 Kilowats, and thus make the searchlights self-supporting.

During the past years only one searchlight has been employed at one time on each train and the results have been on the whole satisfactory. Practices with these searchlights have been carried out at every "run out" of the Armoured Trains, and, by using only one searchlight on each Train, no failures have occurred.

(A separate report is being sent on this matter).

In addition to the above, there is a "Gardner" Motor Engine, mounted on a specially constructed trolley which was built by the S.A.R. Cartage Department. Its capacity is about 10 Kilowats and it is capable of running two searchlights. It is at present in good working order, and has been used at the last three Annual Camps for supplying electrical energy for lighting up the Camp. It is petroldriven and on active service, provided good roads existed, could be taken anywhere but, as was experienced in the Zulu Rebellion, was difficult on high gradients and bad roads.

\section{TRANSVAAL SCOTTISH}

A fine body of men, who have turned out in much better numbers this year than formerly, a change that is most welcome. They are very well handled by the Officers, who are keen and much interested in their work.

The Corps is in a good state of efficiency. Their turn-out, as usual, has been uniformly excellent, and they are very steady and accurate at their drill and 
ment under the supervision and untiring patience of Major Marshall, whose retirement this year will be a great loss not only to the regiment but to the whole Force.

There are 8 efficient signallers and 8 more under instruction, showing that this important branch of work is kept well in mind by the Officer Commanding.

In the field they have been well handled and the work is carried out with intelligence. Though sometimes a little slow, they are dependable and ever ready for hard work, and nothing is too much trouble either for Officers or men.

\section{WITWATERSRAND RIFLES}

The end of the year finds this Corps in an excellent state of efficiency. It is not only in the direction of shooting at which they still stand premier regiment, having won a very large percentage of the competitions open to them, but also in signalling, bayonet fighting, and "skill at arms" generally.

There are 8 efficient signallers and 8 more under instruction, a healthy state of affairs.

Very well turned out and always steady, they are handled by their Officers in a quiet knowledgeable way, and the result is that they are reliable and carry out their work smartly and with spirit. The Non-Commissioned Officers have improved on last year, and are now more helpful to their Officers. The greatest care is now excercised that none but a good class of man is enrolled.

At their field work they have improved in pace, and get to work quietly, and considerable trouble is taken in the important matter of fire direction and control.

\section{TRANSVAAL CYCLE AND MOTOR CORPS}

A better and more efficient Corps than last year. This change has been brought about by the keener spirit displayed by the Officers generally, who, realising that things were not all they ought to be, determined that the Corps should finish the year well.

The personnel is gradually improving, a better stamp of recruit having been enrolled, and the latter half of the year showed that a most encouraging change had come over the Corps as regards turn-out.

Early in the year the numbers on parade were not what they should have been, but this got better towards the latter half, and it was in fact a different regiment that stood to arms at the end of the year as compared with the beginning. I found them much steadier and the old nervousness at drill had disappeared.

Their Non-Commissioned ranks were thoroughly tested as I wished to find out how far their improvement had spread, and it was quite apparent that an increase in general efficiency and keenness had been infused into the ranks, as well as amongst the Officers.

Signalling is entirely neglected in this Corps, a state of affairs that is most unsound.

Very keen in their field work, it was clear that last year's standard had been maintained. At this particular work they are always zealous and do not spare themselves at all. 


\section{TRANSVAAL SIGNALLING AND FIELD TELEGRAPH COMPANY}

The Company has turned out better this year and is fairly smart on parade. The material is good as a large number of the men are Post Office officials.

\section{SIGNALLING SECTION.}

It is not possible to report that there has been the advance this year that I had hoped for. There has been a tangible improvement and there are now 23 efficient signallers, though not many of them are as highly efficient as members of a technical Corps should be. There seems great difficulty in getting the signallers together for practice, and some have put off their work until the last possible week. The efficiency is a good deal better than last year; the handling of the various instruments is less clumsy than formerly, and a better knowledge of their work is displayed, but amongst some a great deal yet remains to be learnt.

\section{CABLE SECTION.}

I can again report that the work of this Section has been most satisfactory. They work smoothly and quietly, displaying a good deal of ingenuity in the tasks allotted to them, consistently showing their value as Telegraphists. They display common sense and resource when dealing with "ground cables" on "air lines", and move at a very fair pace.

\section{TRANSVAAL MEDICAL CORPS}

The same intelligent class of men has been enrolled as formerly, amongst whom is a large number of Dispensers who would be most useful on service. It might have been expected that by introducing such a large number of recruits, namely 95, into an actual strength of 187 the Corps might become seriously less efficient, but these recruits have been so well handled that, whilst there is no falling off in any direction as far as I can find, there has been an advance as regards turn-out and drill, and the general standard of musketry shows an improvement.

A great deal of interest is displayed by the Officers to make this Corps really serviceable, and their efforts have met with great success. Usually Volunteering means a complete change of work to Officers and consequently something in the nature of a relaxation, hence the greater probability of interest being taken. The fact that the Officers of the Medical Corps do the same kind of work when Volunteering as they do in civil life and yet show a most exemplary zeal and enthusiasm, reflects, I consider, the greatest credit on them.

The turnout could not, I think, be bettered, and tranquility and alertness always marked their drill.

When at purely medical work and stretcher drill etc. one finds always an anxiety for a lot of work, and nothing in the nature of slackness is detected.

It is proposed to considerably extend their work during the manoeuvres and field days for the coming year.

\section{SIGNALLING}

In Appendix $\mathrm{K}$ will be found the distribution of the number of efficient signallers in each Unit, making a total of 55. In view of the great amount of communication work necessary in the event of trouble, this number cannot be considered really 
Transvaal Horse Artillery, South African Railway Engineer Corps, Transvaal Scottish and Witwatersrand Rifles. The Imperial Light Horse and Northern Mounted Rifles have none at all, whilst the Southern Mounted Rifles and Transvaal Cycle and Motor Corps have but two apiece, though the Southern Mounted Rifles have six under instruction. In the case of the Northern Mounted Rifles and Southern Mounted Rifles, it is most difficult to get men to take an active part in this important subject, partly perhaps on account of the difficulties of instruction. Scattered over very large areas, they have not the opportunities of the Urban Volunteers. The Northern Mounted Rifles are arranging a scheme in the Pietersburg District whereby a fair number of signallers will get trained, and it should be successful if a spirit of keenness and determination to overcome obstacles and the first dull work of learning be displayed. The case of the Imperial Light Horse and Transvaal Cycle and Motor Corps is quite different. There is no reason, as far as I can see, why these two Corps should not be in possession of a good number of efficient signallers, sufficient to take the field with. Both Corps have been called on to make extra efforts this year to supply this defect, and it is to be regretted that some serious move has not been made to get men trained. It should be mentioned that all the Officers and Non-Commissioned Officers of the Pretoria Detachment of the Transvaal Cycle and Motor Corps have passed the required test in semaphore, which is very creditable, but they must have their proportion of fully trained and efficient "Morse" signallers, as must the Imperial Light Horse.

\section{TRANSVAAL HORSE ARTILLERY.}

In the Transvaal Horse Artillery signalling in general has this year shown a marked improvement. It is gratifying to note that although their men have other duties to perform in connection with their batteries, they are keen enough to devote a great amount of extra time in learning signalling. They have 11 trained men out of an establishment of 150 , the highest percentage of any Corps. Great credit is due to those responsible for this instruction and for the keenness and energy displayed.

\section{SOUTH AFRICAN RAILWAY ENGINEER CORPS.}

The Engineers take a great interest in this matter, and have done excellently. They have 10 efficient signallers and a good number under instruction. They are most reliable at all branches of this work, and won the Signalling Shield at the end of the year with a high percentage.

\section{TRANSVAAL SCOTTISH.}

The Corps has 8 efficient signallers, who have arrived at a fair standard. Good progress has been made in the Pretoria Detachment, but the matter requires some pushing in Johannesburg, and I understand the Commanding Officer has the matter in hand.

\section{WITW ATERSRAND RIFLES.}

The Witwatersrand Rifles finished the year well with 13 efficient and reliable signallers who have done excellent work. This matter is not neglected, and they have other men under instruction.

On field days signalling has been much more used than formerly, and its uses have been better understood. The Staff Signalling Officer, who has worked very hard throughout the whole year, has, on occasions, devoted himself entirely to 
the signalling schemes of the opposing parties and has not been detailed for other duties. The consequence is one sees much more intelligence displayed in the handling of signallers and regimental Officers take an increased interest in the matter. There is, of course, much to be learnt yet and efforts are being made to get those connected with signalling thoroughly instructed in map-reading, compasses, etc., a knowledge which is essential if the work is to be carried out intelligently.

Thirteen of all ranks have taken the Volunteer Signalling Certificate, which requires a standard of knowledge similar to that necessary to obtain an Instructor's Certificate in the Army. In consequence we are now well supplied with Officers and men who are in a position to instruct in all branches of this work.

\section{WIRELESS TELEGRAPHY.}

I cannot too strongly urge the adoption of wireless telegraphy. The immense power given to the force using it would alone, I consider, justify the expense, which is somewhat heavy, and I hope this matter will be seriously considered in the near future. It is practically independent of climate, which cannot be said of the other instruments in use, and also of irregularity of country. Communications are often almost impossible, or they use up an enormous number of stations, that is men, owing to the broken-up hilly nature of the country. Wireless is not affected by these considerations and, further, the most modern apparatus gives a very much greater range than any other of the instruments used. Messages cannot be tapped or intercepted, wires cannot be broken, and all the advantages are on the side of those who adopt it.

\section{MANOEUVRES}

Some good work has been done during the year, and though there have been a good many mistakes, plenty of spirit and enthusiasm has been shown. Early in the year situations were none too readily grasped, hesitation and lack of confidence being evident. These defects in some mysterious way spread rapidly through all ranks and the work suffered in consequence. More confidence came to all as the season went on. Orders are now generally concisely and clearly issued. This helps all ranks considerably and there is in consequence much less guessing at the Commander's intentions. In some cases orders were drafted and edited by a Staff Officer. This should be avoided as it may point to a want of knowledge of the correct method of drawing up these orders on the part of a Commander. The idea of leaving the detail for the carrying out of a plan to Subordinate Officers is encouraged, and Seniors now recognise that it is impossible to personally supervise and control all the various work in the Field. At the same time, situations arose occasionally when all troops were hanging on the Commander for instructions, and they could get none. More initiative on the part of the Junior ranks can only be expected when Commanders realise that as far as possible all concerned in the operations should be acquainted with the object in view, and steps to spread that information are taken.

In scouting too many men are still employed in some cases, but greater care is exercised to do the work as far as possible without attracting attention. Unfortunately over-bold scouts are still to be found who are quite reckless as regards fire. This over-boldness takes the form of neglect to take advantage of cover, regardless of the fact that a scout who has gathered in a lot of information is of no value the moment he becomes a casualty.

It is difficult to get them to realise that they are not only training themselves in an unreal direction but that by their actions they have a tendency to give away the 
situation of their own Commander. Likewise, I have noticed that if a party of men are told to "demonstrate" they do it with so much zeal and create such a dust that none but the absolutely ignorant could be deceived by the scheme. The best scouts are in the District Corps, where a good deal of sound sense is displayed. But in their case communication between scouts and their troop and squadron leaders is not sufficiently maintained.

For the most part noise, creating a dust and disorder have disappeared, and as there is in consequence less excitement there is naturally more effective work. The unnecessary exposure and indifference to fire shown on these field days cannot, I believe, be entirely eradicated during peace time, and these faults show no improvement on last year.

Of "bunching" there has been less, but it seems always with us. The improvement is due to better handling by junior Officers and Non-Commissioned Officers and to the decrease in excitement and noise.

Communications are not well kept up between the different arms and units; the Commanders themselves made more effort but there is still a great deal to be done in this direction, and troops adjacent to each other hardly realise the importance of the matter. Sometimes Officers were at a loss whether to open messages or pass them on, and occasionally there was uncertainty as to who actually commanded at certain points.

As reported elsewhere, the Signalling was a great deal better, but written messages frequently took an undue time to reach their destinations, and verbal messages usually arrived mutilated. Lateral communication and inter-communication between arms and units is almost entirely neglected.

The support of one arm of the Service by another is frequently not understood, and one sometimes found that mounted men were detained on a duty that might just as well have been done by Infantry, thus sacrificing mobility and consequently initiative.

A considerable interest in fire control is now shown, but more practice is needed. It is a matter requiring constant attention in order that ammunition may be fostered and the men kept in hand as long as possible. The infantry proved themselves faster on their legs than formerly, and Junior Officers and Non-Commissioned Officers showed more control of their men. Their work is much more quietly performed.

Amongst the mounted men there is not sufficient dismounting and off-saddling. Long waits in the saddle tend to unnecessarily tire the horses. Again, "led" horses were often taken out of, and brought into, action too slowly and not by the most sheltered route. Rapidity of movement is very largely practiced, a matter that is encouraged as long as it is exercised economically, having due regard to the wear and tear on the horses, and common sense is shown to use pace only when really required and when something is to be gained.

The positions chosen by the Artillery were usually well selected, but guns were occasionally brought into action without the ground in front and to the flanks being properly examined. Once in action the tendency to move guns rather than alter the range was not so apparent as formerly. More advantage was taken of cover and the batteries were more cleverly handled. When moving from one position to another no time was lost, and they went at the fastest pace possible with their present draught animals, realising that guns lumbered up and moving have no offensive power. 
This year Maxims were organised into Batteries of six guns, having previously been formed into regimental sections of two guns each. It worked well and gave machine gun Commanders an insight into the proper working of these guns as a battery. This method of training will be considerably pushed during the coming year.

\section{ANNUAL CAMP}

The same site as last year was selected for the Annual Camp and, as before, it proved very convenient.

A great deal of work was put in. The interior arrangements of the Camp as regards supply and transport worked without a hitch and this is satisfactory in view of the daily change in the number attending Camp.

The site of the camp was a very healthy one and there was no sickness. Medical arrangements were quite adequate, and very clear orders were issued as regards sanitation. By degrees all ranks are learning the great importance of this matter, and the sanitary regulations were well carried out in nearly all cases.

The Veterinary arrangements were satisfactory, and the few cases of sick horses were attended to at once.

The Post and Telegraph services worked without a hitch, and the Field Telegraph and Signalling Corps put up an excellent system of telephonic communication between Headquarters and all Units, thus materially assisting the work in camp.

The Northern Mounted Rifles were unable to concentrate owing to the expense, and it was decided that it was unwise to attempt to bring in the South African Railway Engineer Corps owing to the difficulties all ranks experience to get off their Railway work at a time when there is increased Holiday traffic. In consequence they held their Camp at Brits during May. All the remaining Corps of Volunteers were present, as were also the 1st Cadet Battalion, Witwatersrand Rifles. A record was put up as regards numbers, the greatest number in camp on any one day was 2,354 , and with two Corps absent representing 1,000 men, this is, I think, most satisfactory.

The Transvaal Horse Artillery devoted all their time, except when they co-operated in the field on 17th April, to shooting, and good ground was selected for them to practice over.

The Mounted and Dismounted Corps put in a lot of regimental work, and the Field Telegraph and Signalling Company and Transvaal Medical Corps confined themselves chiefly to technical instruction.

The camp was run on the most business lines possible, and the strictest discipline was enforced. The money spent on these camps realizes better value perhaps than any other spent during the year, and the force would undoubtedly deteriorate considerably were these camps dropped, for they are the only opportunities to get the force together in really large numbers, when each branch can not only put in a deal of work under the best possible conditions and continuously, but can watch the workings of the other branches and thus gather in useful information.

\section{STAFF RIDES}

These again proved unsatisfactory. The attendances were bad and insufficient interest was shown. I do not propose to continue them for the coming year, but shall substitute instead "Regimental Tours", which will give the more Junior Officers an opportunity of studying Staff and Regimental duties in the Field. 
From the number of applications received during the past two years from Junior Officers, to be allowed to attend the Staff Rides, there is reason to believe that the Regimental Tours will receive good support.

\section{LECTURES}

In addition to a large number of Lectures given under Regimental arrangements by Commanding Officers or Adjutants or Corps Officers, two series of lectures were given in all subjects for the Higher Proficiency Examinations by Adjutants specially selected for the work. The lectures on general subjects were increased in number. The attendances all round were very fair.

\section{CHART AND COMPASS COMPETITION}

Over a somewhat more difficult course the work was better carried out than previously, and this advance is commendable.

There was evidently somoling wanting in the scouting, the winning team of the Transvaal Horse Artillery being the only one to carry out this important work really correctly and effectively.

There was a tendency to give up the competition too soon. Since in patrol work the thorough searching of the ground is absolutely essential, though always difficult and often tiresome, it seems a pity that there should be an inclination to give up before the work is completed.

Except for one team the turn-out was excellent, and the condition of the horses at the end of the competition was most satisfactory, showing that good horsemastership had been exercised.

With the exception of the winning team the reports and sketches left a good deal to the imagination. Here again the fault of insufficient scouting was shown.

\section{LONG DISTANCE MARCHING AND SZIOOTHNG COMPETITION}

The entries were very good, 19 teams appearing at the starting point. The remarks by the Judges go to show that an improvement had taken place, and as the competition is a most instructive one, criticisms of all teams were issued as soon after the competition as possible. Briefly summed up, they show that whilst most patrols were well and sensibly handled, in some cases the scouting was defective and the general handling of Infantry Patrols was not understood. Advantage of cover was sometimes neglected, and Patrol Officers were occasionally unnecessarily exposed. The control of fire was almost invariably good, and the shooting at unknown distances was generally most effective.

\section{MUSIKETRY}

The standard of shooting in the force is still very good. The points for efficiency were raised this year, but the increase caused no difficulties and the number of non-efficients in musketry is due to the fact that the shooting was not performed, not to the fact that the standard was too high. The new course brought in two years ago, which replaced the old Bisley targets by those more likely to be met with on service, and which enabled men to practice shooting under conditions as nearly as possible resembling those met with in War, has received the loyal support of all, and its many advantages are appreciated by the majority of thoughtful 
Volunteers, more particularly in the Country Districts, where Snap and Rapid shooting are best understood. The old expert Bisley shots shine equally at this new course, and it is satisfactory to report that many of them encourage the younger men by helping to train them.

\section{PERMANENT STAFF}

The work performed by the Staff Officers, Adjutants, (including those partially paid), and the Subordinate Permanent Staff has been very heavy this year, and I have to record the excellent spirit in which all duties have been performed. Administration has worked smoothly and almost without exception the dominating feature is the desire to overcome difficulties and not to make them. The duties have been very varied for all, but work out of the beaten path has usually been met with a readiness to deal with new and exceptional situations. A few additional Sergeant-Instructors are really necessary, as, with the present Staff, it is not possible to give the amount of attention and instruction to those scattered over the Districts that one could wish.

\section{HORSES}

A good useful stamp on the whole. Those in the Towns are pretty much the same as formerly, but the tendency to be mounted on big horses has dropped out, all realising that the Cob of the Country is the more useful animal for the work entailed.

Owing to two good years as regards horse-sickness, the animals in the Districts have improved somewhat in quality, and this was particularly noticeable with the four squadrons of Northern Mounted Rifles at Pietersburg and North of that place. Horse-sickness practically devastated that District two years ago, but a recovery has set in and one finds the general rule now is that the horse obtainable is hardy and useful and up to a lot of work.

\section{CORONATION CONTINGENT}

To attend the Coronation Ceremony of His Majesty King George V, 120 Officers and Men were selected. Preference was given to those who had taken the most interest in, and done the most for, the Volunteers, and the Contingent was proportionately representative of all Units.

An inspection of the Detachment before departure showed that the physique and bearing were worthy of the Province, and all ranks appreciated the honour that had befallen to them as representatives of the Force.

\section{RANGES}

The Ranges are in a very good condition. In one or two cases there has been a certain amount of neglect, but as the supervision has been thorough the defects were soon remedied. New ranges have been erected at Rietfontein, and the coming year will necessitate a certain amount of expansion.

\section{GUNS}

The number of guns remains the same as last year. I hope that the question of re-arming " $B$ " Battery with a modern quick firer in place of their present 15 pdrs. may soon be considered, as they are seriously handicapped by the present weapon.

Our supply of Maxims is still too small, and their number should be increased. 


\section{SMALL ARMS}

We are in possession of the M.L.E. rifle, Mark I and Mark IX. They are in a thoroughly serviceable condition and are well looked after, being constantly inspected. Returned arms are not admitted to the Armoury until they have been thoroughly examined, and in consequence they are always ready for re-issue. This work is very well carried out by the responsible Staff.

Many barrels were replaced during the year on re-payment and 139 were renewed free on account of fair wear and tear.

700 Rifles have been disposed of to members of recognised Rifle Clubs, as against 119 last year. This sale of rifles is seriously increasing the work, and the demand for rifles shows no signs of diminishing.

\section{AMMUNITION}

(a). GUN.-We are now in possession of the reserve ammunition sanctioned last year, and our position in consequence is very much stronger;

(b). SMALL ARMS.-The ammuntion is of the best quality and gives every satisfaction. We have in hand now the reserve ordered last year.

\section{EQUIPMENT}

Except for fair wear and tear, this is in the same condition as last year, and it is all serviceable. As more equipment is required, I strongly recommend that the new "Mills Web Equipment" be obtained. It is a great improvement on any other existing.

\section{CAMP EQUIPMENT}

There is sufficient for 6,000 men, and it is kept in good condition. Worn-out blankets are gradually being replaced and 700 are on order at present. This applies also to various parts of tents which have become worn-out.

\section{UNIFORM}

As formerly, this is obtained by Contract as required, but we ought to hold a larger reserve in case of emergency. I have mentioned the question of the desirability of stocking great coats for the force elsewhere in this report.

\section{SADDLERY}

There are 400 sets of saddlery in reserve.

\section{MILITARY LIBRARY}

The number of books in the Library still stands at 310 , the same as last year,

but another batch is being purchased shortly. A good deal of use is made of this Library by the keener Officers. 


\section{CADETS}

\section{SENIOR CADETS}

This Corps has not maintained its numbers and has fallen from 489 of all ranks in 1910 to 339 on the 30th June 1911. This is due to the breaking up of one complete Company and to a feeling of uncertainty amongst all ranks concerning what the future holds for the Battalion. I do not think there is likely to be any change in this direction until the new scheme is published, but the Officers remaining in the Corps are working hard to keep it together, and are trying to get good work out of the Cadets, though there is not the same enthusiasm as formerly, due to the cause mentioned above.

The percentage of efficients for the year is 61.97 , which is distinctly bad.

The discipline has been good and a fair amount of work has been got through. They are very well turned out, and their drill is always steady and quiet, whilst they handle their arms well.

The Corps again attended the Easter Camp of Volunteers with a good deal of benefit to themselves. They take the work seriously, and amongst them is a number of youths over 17 years of age ready and fit to take their places in the ranks of the Volunteers should their services be required.

The Corps does very little field work beyond that performed in Camp in conjunction with the Volunteers.

It is regrettable that Signalling is not taken up in this Corps, as the members are just at the age to learn the subject readily and would be of greater value when passing into the Volunteers.

In the early part of the season about 25 Cadets were passed through Gunnery, but the classes were discontinued on account of the pressure of work making it inconvenient for the Transvaal Horse Artillery and difficult for the Cadets to attend. A few are still attending at the Gun Sheds. The boys take great interest and show aptitude, and the move is distinctly a good one.

The actual results in Musketry are most unsatisfactory. The percentage of efficients is only 57.47. This unfortunate result is due entirely to one Company which sent in no Musketry Returns at all, owing to the neglect on the part of the Officers. These Officers have since been permitted to resign. Exclusive of that Company, the percentage would have been over $80 \%$.

\section{SCHOOL CADETS}

\section{STRENGTH.}

There is a reduction in numbers for this year of 193, due to the disbandment of some of the smaller companies existing in outside districts, which it was thought inadvisable to keep on owing to a proper and regular supervision being impossible. The same policy will be continued this year, and one or two more of the companies will fall out. In all 3,251 of all ranks have been trained during the year.

\section{EFFICIENCY}

The percentage of efficients is 91.73 , which is an improvement on last year by 1.73 per cent. Pretoria stands highest with the very fine record of 98.28 efficient; 
down by the districts, who can only show $83.30 \%$ efficients. This is due to the difficulty of supervision, and could be much improved with an increase in the number of Instructors.

\section{OFFICERS.}

The Officers, with a few exceptions, have worked hard and have shown a great interest in the movement, and nearly all have now passed the obligatory examinations and are posted to the General Reserve of Volunteer Officers. I understand that the remaining few to pass intend presenting themselves for examination at the first opportunity. Forty-nine have passed during the year.

DISCIPLINE.

The discipline is good, but would be improved if the system were made compulsory.

\section{MUSKETRY.}

\begin{tabular}{|c|c|c|c|c|c|}
\hline Marksmen. & $\begin{array}{c}\text { 1st Class } \\
\text { shots. }\end{array}$ & $\begin{array}{c}\text { 2nd Class } \\
\text { shots. }\end{array}$ & $\begin{array}{c}\text { 3rd Class } \\
\text { shots. }\end{array}$ & $\begin{array}{c}\text { Non- } \\
\text { Efficient. }\end{array}$ & TOTAL. \\
\hline 89. & 134. & 631. & 2,246 . & 151. & 3,251 \\
\hline
\end{tabular}

This gives a percentage of efficients of 95.5. During the year the following Trophies, open to all Cadets in South Africa, were won: "Transvaal Cadet InterColonial Shield", "Schumacher Cup", "Arcadia Cup", "Langermann Cup", "Hillside Cup" and "League of British Women Cup". In addition they captured the "Roberts Trophy" and the "Schools of the Empire Junior Competition". Great credit is due for these two last victories as both competitions were open to all Cadets in the Empire.

\section{CAMP.}

The annual camp took place at Florida during the Michaelmas holidays and was very strongly attended, in fact in greater strength than ever before. A good deal of useful work was put in, under strict discipline, including company, battalion, and brigade drills, savage warfare manoeuvres, the attack with fire control and discipline, and in addition they were instructed in the ordinary routine duties of a camp. The boys were reviewed by Field Marshal Lord Methuen on one day, and he expressed himself well satisfied with their appearance and work. The camp gives the only real opportunity during the year of combined work in the field, and is in consequence of the utmost use to the Cadets.

\section{EXTRA SUBJECTS.}

Some $66 \%$ of the companies have taken up extra subjects this year in addition to their drill, musketry and field work. This shows a most satisfactory improvement on last year, when only $25 \%$ had made any effort in this direction. The most popular new subject is Signalling, and Officers cannot do better than train their Cadets in this direction. Military Map-reading is also indulged in by some companies, a most useful subject.

\section{NEW COMP ANIES.}

The following new companies have been formed during the year :

81. Industrial School, Standerton.

82. Government School, Vrededorp.

83. Government School, Cleveland.

84. Pretoria College.

Some schools are waiting to form companies at the present time but the establishment will not admit of it just at present. 


\section{COMPANIES DISBANDED.}

Eight companies have been disbanded during the year, viz

30. Modderfontein, (Dynamite Factory).

53. Springs.

72. Brixton.

79. Piet Retief.

64. Witbank.

44. Potgietersrust.

29. Randfontein.

49. Standerton.

P. S. BEVES,

Colonel,

Inspector, Transvaal Volunteers.

\section{APPENDICES}

APPENDIX A.

COMPARATIVE STATEMENT OF ESTABLISHMENT, STRENGTH, AND EFFICIENCY FOR THE YEARS 1909-10 AND 1910-11.

\begin{tabular}{|c|c|c|c|c|c|c|c|c|}
\hline \multirow[b]{2}{*}{$C O R P S$} & \multicolumn{4}{|c|}{$1909-1910$} & \multicolumn{4}{|c|}{$1910-1911$} \\
\hline & 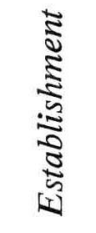 & 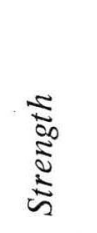 & 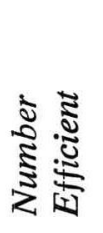 & 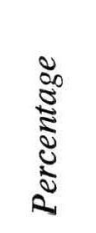 & 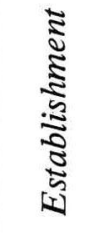 & 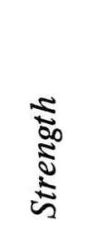 & 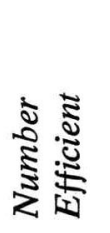 & 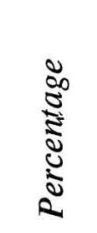 \\
\hline TOTAL - All Corps : & 3832 & 3929 & 3426 & 88.45 & 3912 & 4166 & 3615 & 87.12 \\
\hline T'vaal H. Artillery & 180 & 168 & 164 & 97.61 & 180 & 161 & 157 & 97.51 \\
\hline Imperial Light Horse & 500 & 494 & 442 & 89.47 & 500 & 548 & 467 & 85.21 \\
\hline Northern Mtd. Rifles & 500 & 456 & 410 & 89.91 & 500 & 549 & 465 & 84.69 \\
\hline Southern Mtd. Rifles & 600 & 662 & 556 & 89.38 & 600 & 630 & 544 & 86.34 \\
\hline S.A.R. Engineer Corps & 500 & 573 & 468 & 81.55 & 500 & 561 & 547 & 97. 5 \\
\hline Transvaal Scottish & 400 & 470 & 448 & 95.31 & 400 & 501 & 420 & 83.83 \\
\hline Witwatersrand Rifles & 500 & 523 & 474 & 90.63 & 500 & 537 & 490 & 91.24 \\
\hline T'vaal C. and M. Corps & 320 & 325 & 268 & 82.70 & 400 & 383 & 275 & 71. 8 \\
\hline T'vaal S. and F.T. Corps & 50 & 65 & 31 & 47.69 & 50 & 53 & 37 & 69.81 \\
\hline T'vaal Intel. Corps $^{*}$ & 50 & 13 & & & 50 & 12 & & \\
\hline T'vaal Transport Corps * & 10 & 1 & & & 10 & 2 & & \\
\hline T'vaal Supply Corps * & 10 & & & & 10 & 1 & & \\
\hline T'vaal Medical Corps & 200 & 177 & 165 & 93.22 & 200 & 226 & 203 & 89.82 \\
\hline T'vaal Vet. Corps * & 12 & 2 & & & 12 & 2 & & \\
\hline
\end{tabular}

* Exempt from performing the Drill and Musketry courses prescribed for Efficiency. In calculating the Force percentage their numbers are therefore deducted from the "Strength" column.

NOTE_The "Strength" and "Efficiency" columns represent the numbers who passed through the books during each financial year, i.e., the Volunteers who had opportunity to become efficient. 


\section{RESERVE}

APPENDIX B.

\begin{tabular}{l|rr|rc}
\hline \multirow{2}{*}{ C O R P S } & \multicolumn{2}{|c|}{$1909-1910$} & \multicolumn{2}{c}{$1910-1911$} \\
\cline { 2 - 5 } & Establishment. & Strength. & Establishment. & Strength. \\
\hline Transvaal Horse Artillery & 90 & 56 & 90 & 77 \\
Imperial Light Horse & 250 & 157 & 250 & 147 \\
Northern Mounted Rifles & 250 & 314 & 800 & 643 \\
Southern Mounted Rifles & 300 & 151 & 300 & 158 \\
S.A.R. Engineer Corps & 250 & 90 & 250 & 117 \\
Transvaal Scottish & 200 & 30 & 200 & 40 \\
Witwatersrand Rifles & 250 & 101 & 250 & 113 \\
T'vaal C. and M. Corps & 200 & 46 & 200 & 56 \\
T'vaal Sig. \& F. Tel. Coy. & 25 & 24 & 25 & 232 \\
T'vaal Intelligence Corps & 25 & 5 & 25 & 4 \\
T'vaal Transport Corps & 40 & 2 & 40 & 2 \\
T'vaal Supply Corps & 20 & 4 & 20 & 4 \\
T'vaal Medical Corps & 100 & 73 & 100 & 89 \\
T'vaal Veterinary Corps & 50 & 26 & 50 & 27 \\
General Reserve & 50 & 3 & 50 & 6 \\
\multicolumn{1}{c}{ TOTALS : } & 2,100 & 1,082 & 2,650 & 1,715 \\
\hline
\end{tabular}

APPENDIX C.

MUSKETRY CLASSIFICATION FOR THE YEAR 1909-1910.

\begin{tabular}{|c|c|c|c|c|c|c|c|c|}
\hline & \multicolumn{7}{|c|}{ EFFICIENTS } & \multirow[b]{2}{*}{ 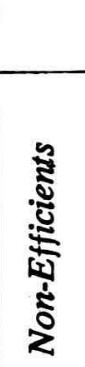 } \\
\hline$C O R P S$ & 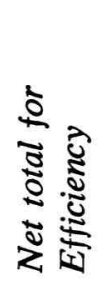 & 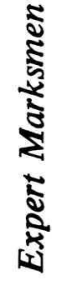 & 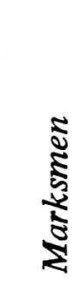 & 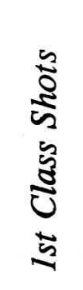 & 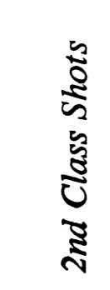 & 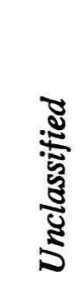 & 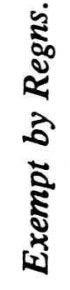 & \\
\hline TOTAL - All Corps : & 3,813 & 47 & 964 & 923 & 1,210 & 159 & 79 & 431 \\
\hline Imperial Light Horse & 496 & 7 & 131 & 139 & 139 & 20 & 9 & 51 \\
\hline Northern Mtd. Rifles & 456 & - & 70 & 120 & 208 & - & 14 & 44 \\
\hline Southern Mtd. Rifles & 623 & 1 & 194 & 172 & 183 & - & 9 & 64 \\
\hline S.A.R. Engineer Corps & 574 & 8 & 151 & 160 & 149 & 17 & 9 & 80 \\
\hline Transvaal Scottish & 476 & 6 & 94 & 110 & 185 & 51 & 7 & 23 \\
\hline Witwatersrand Rifles & 529 & 19 & 198 & 118 & 91 & 45 & 10 & 48 \\
\hline T'vaal C. \& M. Corps & 331 & 6 & 73 & 62 & 115 & - & 5 & 70 \\
\hline T'vaal Sig. \& F. Tel. Coy. & 65 & - & 6 & 11 & 14 & - & 1 & 33 \\
\hline T'vaal Medical Corps & 177 & - & 20 & 19 & 91 & 26 & 15 & 6 \\
\hline $\begin{array}{l}\text { 1st Cadet Battn. Wit. Rifles } \\
\text { (Cadets over } 18 \text { years } \\
\text { of age) }\end{array}$ & 86 & - & 27 & 12 & 35 & 一 & - & 12 \\
\hline
\end{tabular}


APPENDIX D.

MUSKETRY CLASSIFICATION 1910-1911.

\begin{tabular}{|c|c|c|c|c|c|c|c|c|}
\hline & \multicolumn{7}{|c|}{ EFFICIENTS } & \multirow[b]{2}{*}{ 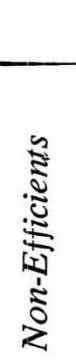 } \\
\hline$C O R P S$ & 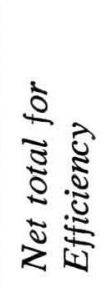 & 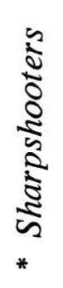 & 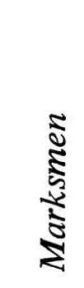 & 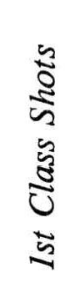 & 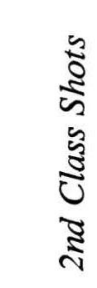 & 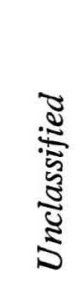 & 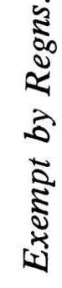 & \\
\hline TOTAL - All Corps : & 4,067 & 93 & 740 & 982 & 1,397 & 103 & 73 & 481 \\
\hline Imperial Light Horse & 548 & 5 & 118 & 147 & 170 & 10 & 13 & 76 \\
\hline Northern Mtd. Rifles & 549 & - & 64 & 89 & 299 & 1 & 12 & 84 \\
\hline Southern Mtd. Rifles & 630 & 2 & 123 & 164 & 257 & 8 & 8 & 68 \\
\hline S.A.R. Engineer Corps & 562 & 7 & 127 & 160 & 245 & - & 8 & 15 \\
\hline Transvaal Scottish & 501 & 20 & 123 & 120 & 137 & 41 & 6 & 45 \\
\hline Witwatersrand Rifles & 537 & 33 & 19 & 150 & 88 & 18 & 6 & 44 \\
\hline T'vaal C. \& M. Corps & 383 & 26 & 104 & 70 & 59 & 18 & 7 & 99 \\
\hline T'vaal Sig. \& F. Tel. Coy. & 53 & - & 14 & 12 & 10 & - & - & 16 \\
\hline T'vaal Medical Corps & 226 & - & 33 & 51 & 101 & 7 & 11 & 23 \\
\hline $\begin{array}{l}\text { 1st Cadet Battn. Wit. Rifles } \\
\text { (Cadets over } 18 \text { years } \\
\text { of age) }\end{array}$ & 78 & - & 15 & 19 & 31 & - & 2 & 11 \\
\hline
\end{tabular}

* Previously termed "Expert Marksman".

APPENDIX E.

\section{THE FOLLOWING ARE THE EFFICIENCY REQUIREMENTS FOR THE YEAR 1910-1911.}

\section{IN DRILL.}

Up to and including the 31st December 1910, drills were held under Regimental arrangements. No Volunteer was allowed to count for such drills more than two-thirds the number required for efficiency.

After the 1st January 1911, drills to count towards efficiency could only be performed at Field Days, the Annual Camp, or at Parades ordered by the Inspector.

No drills are allowed for train journeys to or from Concentrations or Camps.

CONCENTRATIONS of not less than 24 hours duration count as 3 drills.

FIELD DAYS of not less than 3 hours duration count as $\quad . . . . . \quad \ldots . . .62$ drills.

FIELD DAYS of 2 hours and less than 3 hours duration count as 1 drill.

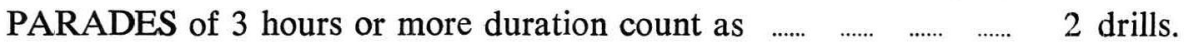

PARADES of not less than 2 hours duration count as $\quad \ldots . . . . \quad \ldots . . . \quad \ldots . . . \quad 1$ drill.

Each complete day's attendance at Annual Camp of Exercise counts 3 drills.

No Volunteer can be returned as efficient for the year who fails to attend the Annual Camp of Exercise or the Annual Inspection, unless he obtains leave from his Commanding Officer. Such leave is only granted for some very special reason. 
APPENDIX F.

EFFICIENCY TABLE.

\begin{tabular}{|c|c|c|c|c|c|}
\hline & Numb & $\begin{array}{r}\text { er of Drills to } \\
a \mathrm{Vo}\end{array}$ & $\begin{array}{l}\text { be performe } \\
\text { lunteer Year }\end{array}$ & $\begin{array}{l}d \text { if serving } d \\
\text { for : }\end{array}$ & uring \\
\hline & $\begin{array}{c}\text { A. } \\
\text { The full } \\
\text { year }\end{array}$ & $\begin{array}{c}B . \\
9 \text { months } \\
\text { or more }\end{array}$ & $\begin{array}{c}C . \\
6 \text { months } \\
\text { or more }\end{array}$ & $\begin{array}{c}D . \\
3 \text { months } \\
\text { or more }\end{array}$ & $\begin{array}{c}E . \\
\text { Less than } \\
3 \text { months }\end{array}$ \\
\hline Artillery & 24 & 18 & 12 & 6 & 4 \\
\hline $\begin{array}{l}\text { Other Mounted } \\
\text { Corps }\end{array}$ & 18 & 14 & 9 & 5 & 3 \\
\hline $\begin{array}{l}\text { Engineers, Infantry } \\
\text { and Cyclists }\end{array}$ & 12 & 9 & 6 & 3 & 2 \\
\hline Medical Corps & $\begin{array}{l}6 \text { Drills. } \\
6 \text { Lectures. } \\
3 \text { B.C. } \\
\text { practices. }\end{array}$ & $\begin{array}{l}4 \text { Drills. } \\
4 \text { Lectures. } \\
2 \text { B.C. } \\
\text { practices. }\end{array}$ & \begin{tabular}{|ll}
3 & Drills. \\
3 & Lectures. \\
2 & B.C. \\
& practices.
\end{tabular} & $\begin{array}{ll}2 & \text { Drills. } \\
2 & \text { Lectures. } \\
1 & \text { B.C. } \\
& \text { practice. }\end{array}$ & $\begin{array}{ll}2 & \text { Drills. } \\
2 & \text { Lectures. } \\
1 & \text { B.C. } \\
\text { practice. }\end{array}$ \\
\hline
\end{tabular}

APPENDIX G.

TABLE “A”. - RECRUITS” COURSE.

PART I.

ELEMENTARY INSTRUCTIONAL PRACTICES.

\begin{tabular}{|c|c|c|c|c|c|c|}
\hline $\begin{array}{c}\text { No. of } \\
\text { practices }\end{array}$ & $\begin{array}{l}\text { Description } \\
\text { of practice }\end{array}$ & $\begin{array}{c}\text { Class of } \\
\text { Target }\end{array}$ & $\begin{array}{l}\text { Distance } \\
\text { in yards }\end{array}$ & $\begin{array}{l}\text { No. of } \\
\text { rounds }\end{array}$ & $\begin{array}{l}\text { Qualifying } \\
\text { points }\end{array}$ & $\begin{array}{l}\text { Instructions } \\
\text { for conduct } \\
\text { of practice }\end{array}$ \\
\hline I. & $\begin{array}{l}\text { Grouping, } \\
\text { Deliberate. }\end{array}$ & $\begin{array}{l}\text { 3rd Class } \\
\text { Bullseye. }\end{array}$ & 100 & 5 & $\begin{array}{l}18 \text { in. ring. } \\
\text { One wide }\end{array}$ & Lying. \\
\hline II. & $\begin{array}{l}\text { Application, } \\
\text { Deliberate. }\end{array}$ & $\begin{array}{l}\text { 3rd Class } \\
\text { Bullseye. }\end{array}$ & 200 & 5 & $\begin{array}{c}\text { shot } \\
\text { allowed. }\end{array}$ & Lying. \\
\hline III. & $\begin{array}{l}\text { Application, } \\
\text { Deliberate. }\end{array}$ & $\begin{array}{l}\text { 3rd Class } \\
\text { Bullseye. }\end{array}$ & 200 & 5 & & Kneeling. \\
\hline \multirow[t]{2}{*}{ IV. } & $\begin{array}{l}\text { Application, } \\
\text { Deliberate. }\end{array}$ & $\begin{array}{l}\text { 3rd Class } \\
\text { Bullseye. }\end{array}$ & 100 & 5 & & Standing. \\
\hline & & & & 20 & 36 & \\
\hline
\end{tabular}

QUALIFICATION PRACTICES - PART II.

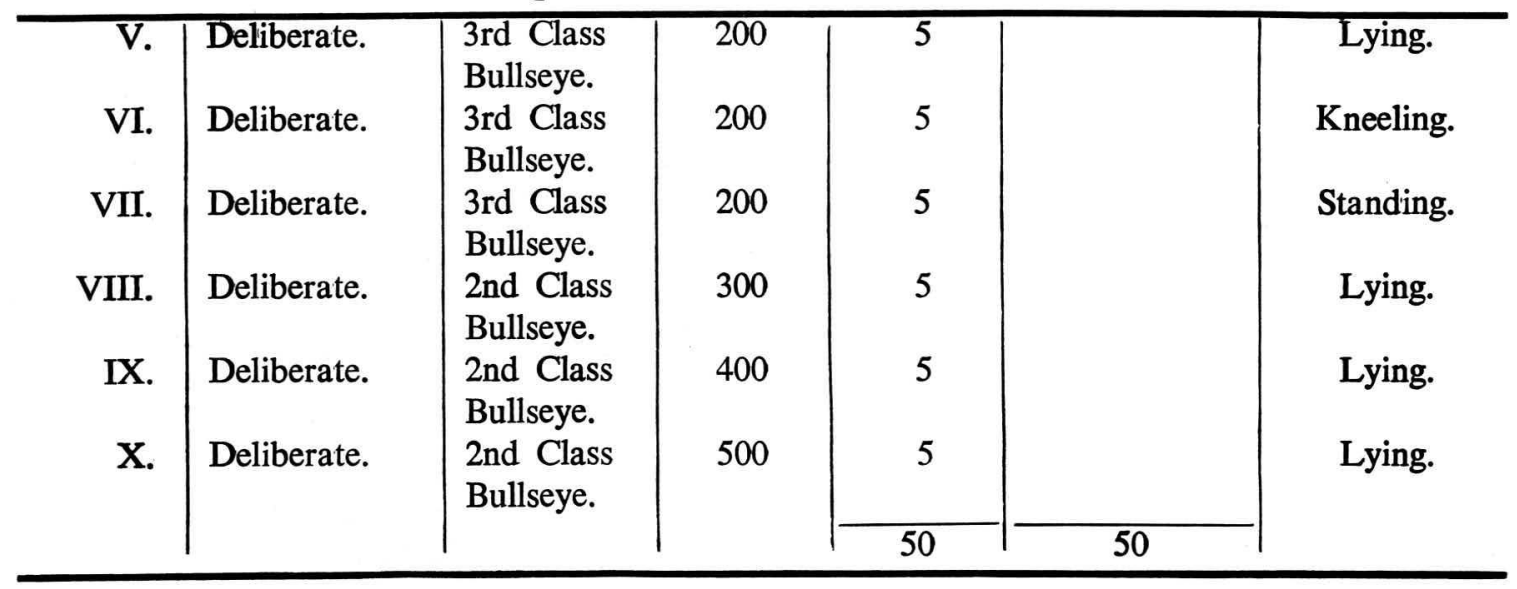


APPENDIX G. (Cont.)

TABLE “B”. - TRAINED MEN'S COURSE.

PART I.

PRELIMINARY PRACTICES.

\begin{tabular}{r|l|l|c|c|c}
\hline $\begin{array}{c}\text { No. of } \\
\text { Practice }\end{array}$ & $\begin{array}{l}\text { Description } \\
\text { of Practice }\end{array}$ & $\begin{array}{c}\text { Class of } \\
\text { Target }\end{array}$ & $\begin{array}{c}\text { Distance } \\
\text { in yards }\end{array}$ & $\begin{array}{c}\text { No. of } \\
\text { rounds }\end{array}$ & $\begin{array}{c}\text { Instructions for } \\
\text { Conduct of } \\
\text { Practice }\end{array}$ \\
\hline I. & $\begin{array}{l}\text { Grouping, } \\
\text { Deliberate. } \\
\text { Application, } \\
\text { Deliberate. }\end{array}$ & $\begin{array}{l}\text { 3rd Class } \\
\text { Bullseye. } \\
\text { 3rd Class } \\
\text { Bullseye. }\end{array}$ & 100 & 5 & Lying. \\
\hline
\end{tabular}

PART II.

CLASSIFICATION PRACTICES.

\begin{tabular}{|c|c|c|c|c|c|}
\hline & & & & & \\
\hline III. & Timed slow. & $\begin{array}{l}\text { 3rd Class } \\
\text { Fig. Targ. }\end{array}$ & 200 & 5 & $\begin{array}{l}\text { Lying behind cover, round } \\
\text { which the man will fire. } 20 \\
\text { seconds allowed for each } \\
\text { shot. }\end{array}$ \\
\hline IV. & Timed slow. & $\begin{array}{l}\text { 3rd Class } \\
\text { Fig. Targ. }\end{array}$ & 200 & 5 & Standing. \\
\hline V. & Timed slow. & $\begin{array}{l}\text { 3rd Class } \\
\text { Fig. Targ. }\end{array}$ & 300 & 5 & $\begin{array}{l}\text { Kneeling behind cover, } \\
\text { over which the man will } \\
\text { fire. } 20 \text { seconds allowed } \\
\text { for each shot. }\end{array}$ \\
\hline VI. & Timed slow. & $\begin{array}{l}\text { 2nd Class } \\
\text { Fig. Targ. }\end{array}$ & 400 & 5 & $\begin{array}{l}\text { Any military position, from } \\
\text { behind cover, round which } \\
\text { which the man will fire. } 20 \\
\text { seconds allowed for each } \\
\text { shot. }\end{array}$ \\
\hline VII. & Timed slow. & $\begin{array}{l}\text { 2nd Class } \\
\text { Fig. Targ. }\end{array}$ & 500 & 5 & Ditto. \\
\hline VIII & Timed slow. & $\begin{array}{l}\text { 2nd Class } \\
\text { Fig. Targ. }\end{array}$ & 300 & 5 & Ditto. \\
\hline IX. & Rapid. & $\begin{array}{l}\text { 3rd Class } \\
\text { Fig. Targ. }\end{array}$ & 200 & 5 & $\begin{array}{l}\text { Kneeling behind cover, } \\
\text { over which the man will } \\
\text { fire. } 20 \text { seconds allowed for } \\
\text { each shot. }\end{array}$ \\
\hline $\mathrm{X}$. & $\begin{array}{l}\text { Snap- } \\
\text { shooting. }\end{array}$ & $\begin{array}{l}\text { Figure } \\
\text { No. } 3 .\end{array}$ & 150 & 5 & $\begin{array}{l}\text { Standing. The target will } \\
\text { appear at different places }\end{array}$ \\
\hline & & & & 40 & $\begin{array}{l}\text { and be exposed for } 45 \\
\text { seconds. }\end{array}$ \\
\hline
\end{tabular}

PART III. - Individual Field Practices -20 rounds. 
APPENDIX $H$.

\section{OFFICERS' PROMOTION EXAMINATIONS.}

Return showing the number of candidates presenting themselves for promotion subjects during the year 1910-1911, and number who qualified :

\begin{tabular}{l|c|c|c}
\hline & $\begin{array}{c}\text { Total number } \\
\text { of } \\
\text { Candidates }\end{array}$ & Passed & Percentage \\
\hline Volunteer Officers & 183 & 163 & 89.07 \\
Cadet Officers & 78 & 48 & 61.53 \\
\hline
\end{tabular}

\section{APPENDIX 1.}

\section{LIST OF OFFICERS WHO HAVE QUALIFIED IN HIGHER PROFICIENCY} SUBJECTS AT EXAMINATIONS HELD DURING THE YEAR 1910-1911.

(a). Military Law and Volunteer Regulations.
Major Macfarlane, D. C.
Imperial Light Horse.
Captain Schlam, S. B.
Witwatersrand Rifles.
Captain Cherrington, W. A. D.
Transvaal Cycle and Motor Corps.
Captain Holmes, E. D.
(S.C.) Hon-Capt. Mills, F. W. School Cadet Corps.
Lieut. Van Mentz, $S$.
School Cadet Corps.
Lieut. Carter, H. C. E.
Witwatersrand Rifles.
Lieut. Webber, J. W.
Witwatersrand Rifles Reserve.
Transvaal Cycle and Motor Corps.

(b). Miltary Engineering.

Major Macfarlane, D. C.

Imperial Light Horse.

Captain Young, B.

Witwatersrand Rifles.

Captain Gifford, J.

Captain Beatty, J. W. S.

Imperial Light Horse.

Witwatersrand Rifles.

Captain Robinson, W. M.

S.A. Railway Engineer Corps.

(S.C.) Lieut. Carter, H. C. E.

Lieut. Cheetham, F. G.

Lieut. Webber, J. W.

Witwatersrand Rifles Reserve.

Transvaal Cycle and Motor Corps.

Transvaal Cycle and Motor Corps.

(c). Tactics.

Major Thackeray, E. F.

Captain Schlam, S. B.

Southern Mounted Rifles.

Lieut. Webber, J. W.

Witwatersrand Rifles.

Transvaal Cycle and Motor Corps.

(d). Topography.

Major Thackeray, E. F.

Southern Mounted Rifles.

Major Harvie, W. L.

Major Conner, W. T.

Lieut. Webber, J. W.

Witwatersrand Rifles.

Transvaal Scottish.

Transvaal Cycle and Motor Corps. 
(e). Horsemastership.

(S.C.) Major Harvey, W. L.

Witwatersrand Rifles.

(S.C.) Captain Schlam, S. B.

Witwatersrand Rifles.

(S.C.) Lieut. Webber, J. W.

Transvaal Cycle and Motor Corps.

The undermentioned Officers have during the Year 1910-1911 become entitled to the letter "(q)" in terms of paragraph 38, Volunteer Regulations :-

Major Thackeray, E. F.

Southern Mounted Rifles.

Major Harvie, W. L.

Witwatersrand Rifles.

Major Conner, W. T.

Transvaal Scottish.

Lieut. Webber, J. W.

Transvaal Cycle and Motor Corps.

“(S.C.)" indicates Special Certificate awarded.

APPENDIX $J$.

\section{SIGNALLING.}

All Signalling Parades at Field Days and Camps, or where specially ordered by the Instructor in Signalling, count towards efficiency.

The individual test for the year is: Flag, Lamp and Helio.

First Class : Read and send service message of 150 letters at the rate of 6 words per minute.

Second Class : Read and send test groups of 100 letters at the rate of 4 words per minute.

SEMAPHORE : First Class - Read and send service message of 200 letters at the rate of 8 words per minute.

Second Class : Read and send test groups of 150 letters at the rate of 6 words per minute.

Viva-Voce Examination, Large Flag Drill, and Helio setting (both classes).

Collective Test: All Signallers (including Instructors) are examined in a test based on tactical schemes set by the Inspecting Officer to judge their collective capabilities. The test entails the use of the telescope with a small flag, but is carried out with heliograph, if weather permits, and with lamp at night.

APPENDIX $K$.

EFFICIENT SIGNALLERS 1910-1911,

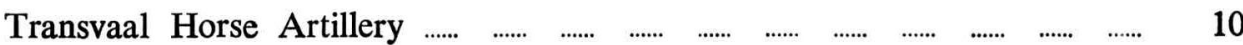

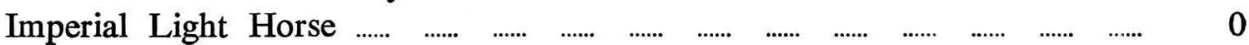

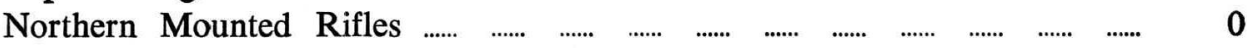

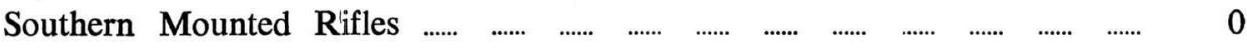

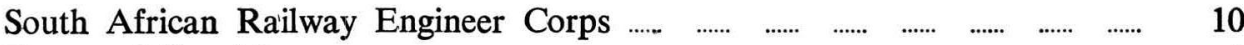

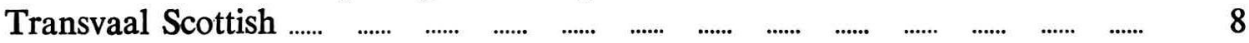

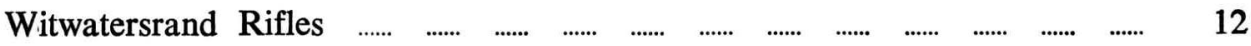

Transvaal Cycle and Motor Corps

Transvaal Signalling and Field Telegraph Company 
APPENDIX L.

PISTOL PRACTICE.

All Officers other than those of the Transvaal Horse Artillery were required to undergo the following course of Revolver Practice to be classed as efficient, in addition to musketry and drill requirements :

Six rounds deliberate practice, right hand; six rounds deliberate practice, left hand; six continuous rounds, right hand; six continuous rounds, left hand.

Qualifying score: $30 . \quad$ Distance: 20 yards. Target: 50 yards Bisley.

The Transvaal Horse Artillery are not exercised in musketry, but fire the following course with the pistol :

Four shots, each consisting of six continuous rounds with the right hand, and six continuous rounds with the left hand.

Qualifying score: $100 . \quad$ Distance: 20 yards. Target: 20 yards Bisley.

APPENDIX $M$.

SCALE OF CAPITATION.

\begin{tabular}{l|c|c|c}
\hline & Artillery & $\begin{array}{c}\text { District and other } \\
\text { Corps with an } \\
\text { establishment over } \\
350 \text { all ranks }\end{array}$ & $\begin{array}{c}\text { Other Corps with } \\
\text { an establishment } \\
\text { under } 350 \text { all } \\
\text { ranks }\end{array}$ \\
\hline For efficiency under A. & £. s. d. & $£$. s. d. & $£$. s. d. \\
For efficiency under B. & 5.0 .0 & 3.10 .0 & 4.0 .0 \\
For efficiency under C. & 3.15 .0 & 2.12 .6 & 3.0 .0 \\
For efficiency under D. & 2.10 .0 & 1.15 .0 & 2.0 .0 \\
For efficiency under E. & 1.5 .0 & 17.6 & 1.0 .0 \\
\hline
\end{tabular}

APPENDIX N.

MACHINE GUN PRACTICE.

PART I. - ELEMENTARY.

\begin{tabular}{|c|c|c|c|c|c|}
\hline No. & $\begin{array}{l}\text { Description } \\
\text { of Practice }\end{array}$ & Targets & $\begin{array}{l}\text { Distance } \\
\text { in yards }\end{array}$ & $\begin{array}{l}\text { Rounds } \\
\text { per man }\end{array}$ & $\begin{array}{l}\text { Instructions } \\
\text { for conduct } \\
\text { of Practice }\end{array}$ \\
\hline I. & $\begin{array}{l}\text { Grouping \& } \\
\text { Application. }\end{array}$ & $\begin{array}{l}\text { Band } 3 \frac{1}{2} \\
\text { ins. deep. }\end{array}$ & 30 & 10 & \multirow{5}{*}{$\begin{array}{l}\text { Ranging fire, } 10 \text { seconds } \\
\text { allowed. } \\
\text { A band } 30 \text { inches long will } \\
\text { be swept with traversing } \\
\text { fire in } 15 \text { seconds. } \\
\text { A band } 36 \text { inches long, } \\
\text { sloping about } \frac{1}{4} \text {, will be } \\
\text { swept with traversing fire } \\
\text { in } 25 \text { seconds. } \\
\text { The gun will be elevated } \\
\text { and depressed while firing. }\end{array}$} \\
\hline II. & Traversing. & do. & 30 & 15 & \\
\hline III. & $\begin{array}{l}\text { Traversing \& } \\
\text { Application. }\end{array}$ & $\begin{array}{l}\text { Diagonal } \\
\text { band } 3 \frac{1}{2} \\
\text { ins. deep. }\end{array}$ & 30 & 15 & \\
\hline \multirow[t]{2}{*}{ IV. } & \multirow[t]{2}{*}{ Searching. } & \multirow[t]{2}{*}{$\begin{array}{l}\text { Band } 12 \\
\text { ins. deep. }\end{array}$} & \multirow[t]{2}{*}{30} & 10 & \\
\hline & & & & 50 & \\
\hline
\end{tabular}


PART II. - INSTRUCTIONAL.

\begin{tabular}{|c|c|c|c|c|c|}
\hline No. & $\begin{array}{l}\text { Description } \\
\text { of Practice }\end{array}$ & Targets & $\begin{array}{l}\text { Distance } \\
\text { in yards }\end{array}$ & $\begin{array}{l}\text { Rounds } \\
\text { per man }\end{array}$ & $\begin{array}{l}\text { Instructions } \\
\text { for conduct } \\
\text { of Practice }\end{array}$ \\
\hline V. & $\begin{array}{l}\text { Grouping \& } \\
\text { Application. }\end{array}$ & $\begin{array}{l}\text { Screen } 1 \\
\text { yard high, } \\
10 \mathrm{ft} \text {. wide. }\end{array}$ & 400 & 30 & $\begin{array}{l}\text { Ranging fire, } 15 \text { seconds } \\
\text { allowed. }\end{array}$ \\
\hline VI. & Traversing. & Collapsible. & 600 & 30 & $\begin{array}{l}\text { Traversing fire, } 30 \text { sec- } \\
\text { onds allowed. }\end{array}$ \\
\hline VII. & Rapid. & do. & 800 & 30 & $\begin{array}{l}\text { Fire will be concentrated; } \\
10 \text { seconds allowed. }\end{array}$ \\
\hline \multirow[t]{2}{*}{ VIII. } & \multirow[t]{2}{*}{$\begin{array}{l}\text { Timed. } \\
\text { Application. }\end{array}$} & \multirow[t]{2}{*}{ do. } & \multirow[t]{2}{*}{$\begin{array}{l}800 \\
\text { to } \\
300\end{array}$} & 60 & \multirow[t]{2}{*}{$\begin{array}{l}\text { Gun to be moved forward } \\
\text { and brought into action at } \\
\text { four different distances. } \\
\text { Time required for moving } \\
100 \text { yards. and making fire } \\
\text { effective to be noted. }\end{array}$} \\
\hline & & & & 150 & \\
\hline
\end{tabular}

PART III. - FIRE DIRECTION PRACTICES.

PART IV. - FIELD PRACTICES.

APPENDIX $O$.

LIST OF PRIZES WON BY TRANSVAAL VOLUNTEERS AT THE TRANVAAL VOLUNTEER MILITARY TOURNAMENT 1910.

Open Tentpegging,

Section Tentpegging,

Balaclava Melee,

Officers' Tentpegging,

Volunteer Tentpegging,

Volunteer Tentpegging,

Volunteer Section Tentpegging,

Volunteer Section Tentpegging,

Volunteer Riding and Jumping, (Individual)

Volunteer Lemon-cutting,

Open Bayonet v. Bayonet,

Open Sabre v. Sabre,

Open Sabre v. Sabre,

Open Foil v. Foil,

Open Foil v. Foil, 4th Prize Tpr. Konigkramer, N.M.R.

3rd „ Northern Mounted Rifles.

2nd , Transvaal Horse Artillery.

1st , Lieut. Tryon, I.L.H.

2nd ” Major White, T.H.A.

3rd , Lieut. Tryon, I.L.H.

1st ” I.L.H. "C" Team.

2nd , I.L.H. "P" Team.

2nd , Lieut. Tryon, I.L.H.

2nd , Farrier Grey, I.L.H.

3rd " Cpl. Stanhope, S.A.R.E.C.

2nd " Sergt. Harris, T.H.A.

3rd " Trooper Gate, N.M.R.

1st , Trooper Gate, N.M.R.

2nd , Sergt. Harris, T.H.A.

2nd „ S.A.R. Engineer Corps. 
Field Ambulance Competition,

Field Ambulance Competition,

Volunteer Bayonet v. Bayonet,

Volunteer Bayonet v. Bayonet,

Volunteer Bayonet v. Bayonet,

Volunteer Bayonet Team Combat,

Volunteer Foil v. Foil,

Volunteer Foil v. Foil,

Volunteer Foil v. Foil,

Volunteer Sabre v. Sabre,

Volunteer Sabre v. Sabre,

Volunteer Sabre v. Sabre, 2nd ” T. Med. Corps, “A” Team.

3rd " T. Med. Corps, “C” Team.

1 st $\quad$ Cpl. Hamilton, S.A.R.E.C.

2nd ” Sapper Ogilvie, S.A.R.E.C.

3rd „ Pte. Storm, T.C. \& M.C.

1st , S.A.R. Engineer Corps.

1st „ Sergt. Harris, T.H.A.

2nd „ Pte. Storm, T.C. \& M.C.

3rd „ Sergt. Briese, Wit. Rifles.

1st $\quad$ Sergt. Harris, T.H.A.

2nd $\rightleftharpoons \quad$ Pte. Storm, T.C. \& M.C.

3rd " Sergt. Briese, Wit. Rifles.

LIST OF WINNERS FROM THE TRANSVAAL VOLUNTEERS AT THE NATAL COLONIAL FORCES TOURNAMENT.

Lloyd Lindsay,

Lloyd Lindsay,

Ring and Peg,

Officers' Lemon Cutting,

Volunteer Tentpegging,

Bayonet Team Combat,

Open Bayonet v. Bayonet,

Volunteer Bayonet v. Bayonet,

Volunteer Bayonet v. Bayonet,

Open Sabre v. Sabre,

Open Foil v. Foil,

Open Bayonet v. Bayonet, 3rd Prize "B" Team, Imp. Light Horse.

4th " “A" Team, Imp. Light Horse.

2nd , Lieut. Tryon, I.L.H.

3rd „ Captain Ross, I.L.H.

1st $\quad$ Cpl. Paul, I.L.H.

1st $\quad$ S.A.R. Engineer Corps.

5th " Sapper Ogilvie, S.A.R.E.C.

1st „ Sapper Ogilvie, S.A.R.E.C.

3rd $\quad$ Cpl. Hamilton, S.A.R.E.C.

1st „ Sergt. Briese, Wit. Rifles.

2nd , Sergt. Briese, Wit. Rifles.

2nd „ Pte. Storm, T.C. \& M.C. 
APPENDIX P.

SHOOTING SUCCESSES DURING THE YEAR 1910-1911.

\section{TRANSVAAL CADET BISLEY MEETING.}

This meeting was held on December 19th, 20th, 21st and 22nd. A large number of Natal Cadets and a few Cadets from Cape Colony attended.

The Arcadia Cup - running man competition - was won by Pietermaritzburg College Cadet Corps. All other Trophies (Team and Individual) went to the Transvaal Cadets. At this meeting Cadet Bekker of the 14th Company, Transvaal Cadets, put up a record for South Africa by making the possible, 105, in the Inter-Provincial Match.

\section{TRANSVAAL BISLEY MEETING.}

This meeting took place on Booysens Ranges from March 18th to 25th, inclusive. All trophies remained in the Transvaal. The Dalrymple Cup - Lloyd Lindsay Competition - was won by the Transvaal Police, and the King's Norton Cup - long range individual competition - by Superintendent Heritage of the Transval Police; all other Bisley Trophies went to members of the Transvaal Volunteers or the Transvaal Volunteer Reserve. At the request of His Excellency the Governor-General, a special competition called the "Governor-General's Cup" was competed for at this meeting. It was won by Sergeant Rallison of the 2nd South Wales Borderers.

\section{CAPE COLONY NATIONAL RIFLE ASSOCIATION'S BISLEY.}

A Team of Transvaal Volunteers attended this Meeting at Cape Town and succeeded in winning the Inter-Colonial Match, the King's, the Grand Aggregate, and a large proportion of the remaining Team and Individual events.

\section{NATAL RIFLE ASSOCIATION'S BISLEY.}

Teams of Transvaal Volunteers and Transvaal Cadets attended this meeting. The Transvaal Volunteers succeeded in winning the Inter-Provincial Match, the Team Championship, the Mackenzie Cup, the Dawson Shield, the Kynoch Cup, the Grand Aggregate, the Aggregate, and a large proportion of the cash prizes, medals, rose bowls, etc. The Transvaal Cadets, individually, won a fair share of the prizes but lost the Inter-Provincial Shield to the Natal Cadets.

\section{INDO-TRANSVAAL MATCH.}

Seven Transvaal Volunteer Teams competed in this Match. The highest score in the Transvaal was made by the Witwatersrand Rifles winning the Bronze Medals - 2nd Prize - in this Competition.

\section{EMPIRE DAY CHALLENGE CUP.}

The Witwatersrand Rifles made the highest score among competing irregular corps, and obtained 9 th position.

\section{METHUEN CUP.}

Open to all Corps in the South African local forces, and won by the Witwatersrand 